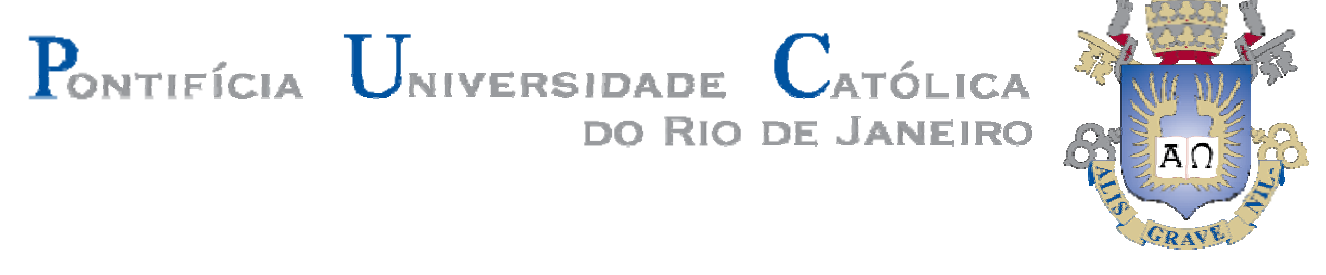

Gil Barreto de Góes

Processo de internacionalização na indústria de jogos eletrônicos brasileira: estudo de casos

Dissertação de Mestrado

Dissertação apresentada ao Programa de PósGraduação em Administração de Empresas da PUCRio como requisito parcial para obtenção do grau de Mestre em Administração de Empresas.

Orientador: Prof. Jorge Brantes Ferreira 


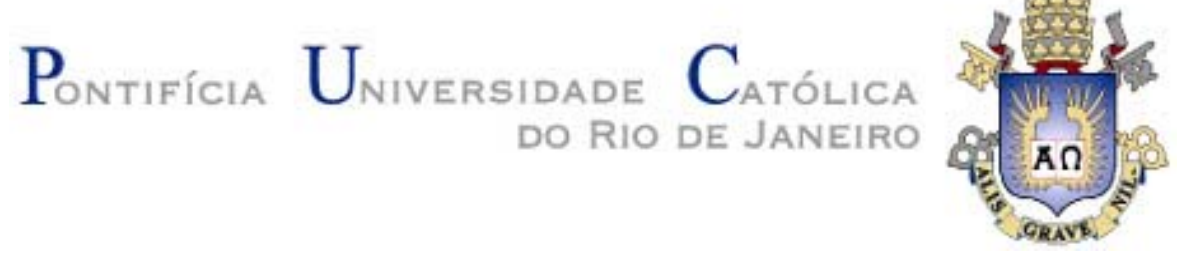

Gil Barreto de Goes

\title{
Processo de internacionalização na indústria de jogos eletrônicos brasileira: estudo de casos
}

\begin{abstract}
Dissertação apresentada como requisito parcial para obtenção do grau de Mestre pelo Programa de PósGraduação em Administração de Empresas da PUC-Rio. Aprovada pela Comissão Examinadora abaixo assinada.
\end{abstract}

Prof. Jorge Brantes Ferreira Orientador

Departamento de Administração - PUC-Rio

Profa. Angela Maria Cavalcanti da Rocha Departamento de Administração - PUC-Rio

Prof. Renato Dourado Cotta de Mello

UFRJ

Profa. Mônica Herz

Vice-Decana de Pós-Graduação do CCS - PUC-Rio

Rio de Janeiro, 31 de março de 2014 
Todos os direitos reservados. É proibida a reprodução total ou parcial do trabalho sem autorização da universidade, do autor e do orientador.

\section{Gil Barreto de Góes}

Graduou-se em Ciência da Computação pela UCAM Universidade Candido Mendes, em 2005. Especializou-se em Logística, pelo Instituto COPPEAD, em 2007, tendo feito o Curso de Formação em Logística. Atualmente é pesquisador do NUPIN - Núcleo de Pesquisas em Negócios Internacionais.

Ficha Catalográfica

Góes, Gil Barreto de

Processo de internacionalização na indústria de jogos eletrônicos brasileira: estudo de casos / Gil Barreto de Góes ; orientador: Jorge Brantes Ferreira. 2014.

139 f. : il. ; $30 \mathrm{~cm}$

Dissertação (mestrado)-Pontifícia Universidade Católica do Rio de Janeiro, Departamento de Administração, 2014.

Inclui bibliografia

1. Administração - Teses. 2. Processo de internacionalização. 3. Empresas nascidas globais. 4. Indústria de jogos eletrônicos. I. Ferreira, Jorge Brantes. II. Pontifícia Universidade Católica do Rio de Janeiro. Departamento de Administração. III. Título. 
Para o meu pai, Pedro Gil, pelo seu apoio e confiança. 


\section{Agradecimentos}

Agradeço a minha família, meus pais Pedro, Cristina e Wanner, que me deixaram o importante legado de amor ao estudo e ao conhecimento. Meus irmãos: Bruno, Daniel e Filippe por todo apoio que me deram durante o curso.

Ao meu orientador, Jorge Brantes pelo incentivo e pelas cobranças para realização dessa dissertação.

Um especial agradecimento a Profa. Angela da Rocha por toda a ajuda que me deu no desenvolvimento da minha dissertação.

Aos professores que participaram da Comissão examinadora.

Agradeço também aos amigos, amigas, familiares que souberam, tantas vezes, compreender pacientemente as minhas repetidas ausências.

A todos os professores do IAG e demais funcionários da PUC-Rio pela dedicação e preocupação em sempre disponibilizar um ambiente agradável aos alunos.

Por fim, agradeço ao CNPq, à Apex, ao PRONEX/FAPERJ/CNPq e ao do Núcleo de Pesquisa em Negócios Internacionais (NUPIN) da Escola de Negócios IAG da Pontifícia Universidade Católica do Rio de Janeiro, pelos auxílios concedidos, sem os quais este trabalho não poderia ter sido realizado. 


\section{Resumo}

Góes, Gil Barreto de; Ferreira, Jorge Brantes. Processo de internacionalização na indústria de jogos eletrônicos brasileira: estudo de casos. Rio de Janeiro, 2014. 139p. Dissertação de Mestrado. Departamento de Administração, Pontifícia Universidade Católica do Rio de Janeiro.

A partir da década de 1990 registra-se crescente interesse no estudo de empresas que apresentam processo de internacionalização rápido e precoce, conhecidas na literatura como Born Globals. O presente estudo investigou o processo de internacionalização de duas Born Globals brasileiras de pequeno porte que atuam no desenvolvimento de jogos eletrônicos. O objetivo deste trabalho foi compreender as motivações, os processos de internacionalização, os fatores que influenciaram negativamente e positivamente a expansão internacional dessas empresas e as estratégias adotadas para se manterem no mercado internacional, sob o enfoque das principais teorias propostas pela literatura. $\mathrm{O}$ estudo foi de natureza qualitativa, utilizando-se o método de estudo de caso. Foram realizadas entrevistas com os principais executivos que atuam na área internacional dessas empresas e levantados dados secundários sobre as mesmas. Paralelamente, foi desenvolvida uma análise do setor de jogos eletrônicos e de sua internacionalização. Por fim, foi possível traçar a evolução do processo de internacionalização das empresas, identificando etapas e eventos importantes, assim como as razões que determinaram as principais ações das empresas, confrontando-se tais resultados com a literatura sobre o tema.

\section{Palavras-chave}

Processo de internacionalização; empresas nascidas globais; indústria de jogos eletrônicos. 


\section{Abstract}

Góes, Gil Barreto de; Ferreira, Jorge Brantes (Advisor). Internationalization process in the brazilian video game industry: case studies. Rio de Janeiro, 2014. 139p. MSc. Dissertation - Departamento de Administração, Pontifícia Universidade Católica do Rio de Janeiro.

Since the 1990s there has been increasing interest in the study of companies that go through rapid and early internationalization processes. The literature refers to these firms as Born Globals. This study examines the internationalization processes of two small Brazilian Born Globals in the video game development industry, from the standpoint of the main theories present in the literature. The objective of this study is to gain a better understanding of these firms' motivations, their internationalization processes, the factors that positively and negatively influenced their international expansion, and the strategies they adopted to survive in the international market, The study is qualitative and employs the case study method. Primary data was gathered through interviews conducted with key executives who work in the international area of the two companies being studied. The study also made use of secondary data from. Parallel to the development of the case, an analysis of the video game industry and its internationalization was developed. Hence, the information gathered made it possible to trace the evolution of the internationalization processes of both companies, identifying important steps and events, as well as getting further insight into the reasons that behind some of the major corporate actions. Finally, these results were confronted with the extant.

\section{Keywords}

Internationalization process; born globals; video game industry. 


\section{Sumário}

1. Introdução 14

1.1. O Problema 14

1.2. Relevância do estudo 16

1.3. Objetivos do estudo 16

1.4. Organização do estudo 17

2. Referencial Teórico 18

2.1. O fenômeno Born global 18

2.1.1. Diferentes definições de Born global 20

2.1.2. Características de Born Globals 25

2.1.3. Determinantes do processo de internacionalização Born global 27

2.1.3.1. Influência das tendências globais $\quad 27$

2.1.3.2. Influência da Internet $\quad 29$

2.1.3.3. Influência dos fatores ambientais do país 31

2.1.3.4. Influência dos fatores específicos da indústria 32

2.1.3.5. Influência dos fatores específicos da empresa e a utilização de redes de relacionamento $\quad 32$

2.1.3.6. Influência dos fatores individuais do empreendedor 35

2.1.4. Sustentabilidade de Born Global 36

$\begin{array}{ll}\text { 3. Metodologia de pesquisa } & 47\end{array}$

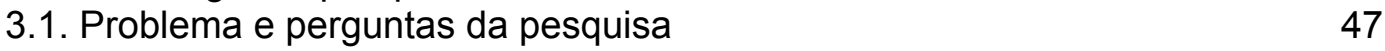

3.2. Método de pesquisa $\quad 48$

3.3. Escolha dos casos $\quad 49$

3.4. Método de coleta de dados $\quad 50$

3.5. Método de análise de dados $\quad 51$

3.6. Limitações do estudo

4. A Indústria de Jogos Eletrônicos 53

4.1. Evolução da indústria de jogos eletrônicos 53

4.2. Segmentação dos jogos eletrônicos 58

4.2.1. Divisão dosjogos eletrônicosde entretenimento 59

4.2.1.1. Social Networks Games $\quad 59$

4.2.1.2. Causal Games $\quad 59$

4.2.1.3. Mobile Games $\quad 59$

4.2.1.4. Massive Multiplayer Online Games 60

4.2.1.5. Console Games 60

4.2.1.6. PC / Macboxed / downloaded games 60

4.2.2. Serious Games $\quad 61$

4.2.2.1. Advergames 61

4.2.2.2. Edutainment 61

4.2.2.3. Game-based Learning $\quad 62$

$\begin{array}{ll}\text { 4.2.2.4. Newsgame } & 62\end{array}$

4.2.2.5. Training and Simulation Games 62

4.2.2.6. Persuasive Games 62

4.2.2.7. Organizational-Dynamic 62

4.2.2.8. Games for Health 62

4.2.2.9. Edumarket
4.3. Publishers e desenvolvedoras da indústria de jogos eletrônicos

4.3.1. Publishers 63

4.3.2. Desenvolvedoras de jogoseletrônicos 64

$\begin{array}{ll}\text { 4.3.2.1. Desenvolvedoras First-Party } & 64\end{array}$

4.3.2.2. Desenvolvedoras Second-Party 64

4.3.2.3. Desenvolvedoras Third-Party 64

4.3.2.4. Desenvolvedores Independentes 65 
4.3.3. Publishers e Desenvolvedoras

4.4. Características da indústria de jogos eletrônicos brasileira 66

4.4.1. Principais Associações do Setor Brasileiro de Jogos 66

4.4.1.1. ABRAGAMES - Associação Brasileira dos Desenvolvedores

de Jogos Digitais

66

4.4.1.2. BGD - Brazilian Game Developers 66

4.4.1.3. SB Games - Simpósio Brasileiro de Jogos e Entretenimento

Digital

4.4.1.4. ACI Games - Associação Comercial, Industrial e Cultural de

Games

66

4.4.2. A Indústria Nacional

67

4.4.3. Mercado de Trabalho

67

4.4.4. Formação de profissionais específicos para a Indústria de jogos eletrônicos

68

4.4.4.1. O Mercado

69

4.4.4.3. Os Cursos de Desenvolvimento de Jogos 70

4.4.5. Políticas de fomento a indústria brasileira de jogos eletrônicos 72

4.4.6. Características de políticas de fomento a indústria de jogos eletrônicos em outros países

4.5. Internacionalização de empresas dejogos eletrônicosno Brasil

5. Casos da internacionalização das empresas Aquiris Games e Manifesto

Games

78

5.1. Aquiris Games

78

5.1.1. Histórico da Empresa

5.1.2. Perfil dos Dirigentes

5.1.3. Processo de Internacionalização 81

5.1.4. Características do Processo de Internacionalização 82

5.1.5. Barreiras à Internacionalização $\quad 87$

5.1.6. Facilitadores para a Internacionalização.

5.1.7. Perspectivas Futuras $\quad 90$

5.2. Manifesto Games 91

5.2.1. Perfil dos Dirigentes $\quad 92$

5.2.2. Histórico e Processo de Internacionalização 93

5.2.3. Características do Processo de Internacionalização 96

5.2.3.1. Downloadable games 96

$\begin{array}{ll}\text { 5.2.3.2. Outsourcing } & 97\end{array}$

5.2.3.3. Receita (Monetização) 99

5.2.4. Barreiras à Internacionalização 100

5.2.5. Facilitadores para a Internacionalização 102

6. Análise dos casos 106

6.1. Determinantes do processo de internacionalização 106

6.2. Escolhas dos países 108

6.3. Barreiras e obstáculos dos processos de internacionalização 109

6.4. Facilitadores dos processos de internacionalização 113

6.5. Sustentabilidade das empresas no mercado internacional $\quad 115$

6.6. Importância da criação de alianças e parcerias 117

7. Considerações Finais 121

7.1. Conclusões 123

7.1.1. O processo de internacionalização das empresas Aquiris e Manifesto 123

7.1.2. A criação de sustentabilidade internacional das empresas

Aquiris e Manifesto

7.2. Recomendações para a prática empresarial 125

7.3. Recomendações para estudos futuros 127 
8. Referências Bibliográficas 128

9. Referências da Análise da Indústria de Jogos Eletrônicos 131

10. Anexos 133

10.1. Anexo 1 - Exemplos de Jogos Eletrônicos Desenvolvidos pela
Aquiris

10.2. Anexo 2 - Unity Technologies 136

10.3. Anexo 3 - Jogos Eletrônicos Desenvolvidos pela Manifesto

10.4. Anexo 4 - Notas e Referências dos casos 138 


\section{Lista de figuras}

Figura 1 - Tipos de INV 22

Figura 2 - Modelo de Forças que Influenciam a Velocidade da

Figura 3 - Elementos necessários e suficientes para INV Sustentável 37

Figura 4 - Modelo conceitual da influencia dos fatores do empreendedorismo de marketing no desempenho de BGs. 42

Figura 5 - Modelo conceitual das estratégias chave de internacionalização utilizadas por pequenas BGs.

Figura 6 - Estrutura de negócio da indústria de jogos eletrônicos nas décadas de 1970 e 1980.

Figura 7 - Estrutura de negócio da indústria de jogos eletrônicos atualmente 


\section{Lista de quadros}

Quadro 1 - Classificação BG para novas empresas 24

Quadro 2- Classificação INV de novas empresas 24

Quadro 3 - Características das Born Globals Aquiris Games e Manifesto
Games

Quadro 4 - Desenvolvedoras de Consoles e seus Videogames. 54

Quadro 5 - Ranking dos principais publishers no mundo em $2012 \quad 63$ 


\section{Lista de tabelas}

Tabela 1 - Classificação das Born Globals Proposta por Madsen

20

Tabela 2 - Filiação de categorias da indústria, de acordo com a classificação INV 


\section{1 Introdução}

Este estudo investiga o processo de internacionalização precoce de duas empresas brasileiras de jogos eletrônicos, utilizando o método de estudo de casos, com o propósito de identificar os motivos para essas empresas buscarem o mercado exterior de forma acelerada e como elas conseguem se tornar sustentáveis em um mercado internacional tão competitivo. Neste trabalho os termos "sustentável" e "sustentabilidade" são usados para indicar a manutenção e crescimento das atividades das empresas no mercado internacional ao longo do tempo.O estudo se insere na linha de pesquisas de internacionalização de empresas conduzida pelo NUPIN (Núcleo de Pesquisas em Negócios Internacionais) da Escola de Negócios da PUC-Rio (Pontifícia Universidade Católica do Rio de Janeiro) e com o apoio da Agência Brasileira de Promoção de Exportações e Investimentos (APEX).

\section{1. \\ O problema}

A indústria de jogos eletrônicos (games) na década de 1980 foi marcada pela forte presença de publishers ${ }^{1}$ internacionais que eram responsáveis pela promoção e distribuição dos jogos, comercializados no varejo.

Na década de 1990, o mercado de jogos eletrônicos começou a apresentar algumas mudanças, devido à popularização da internet que permitiu maior acesso à distribuição digital. Nessa época surgiram pequenas empresas desenvolvedoras de jogos eletrônicos que passaram a distribuir seus jogos por meio de websites e ferramentas desenvolvidas pelas produtoras de consoles de jogos eletrônicos que permitiam a venda direta dos jogos, diminuindo assim a dependência das produtoras de jogos em relação aos publishers.

${ }^{1}$ Publishers, dentro do contexto de jogos eletrônicos, são empresas responsáveis pela publicação de jogos eletrônicos, que podem ser desenvolvidos pelos próprios Publishers ou por outras empresas. No capítulo0 os Publishers serão abordados com mais detalhes. 
$\mathrm{Na}$ década de 2000, surgiram inúmeros publishers de jogos online, que disponibilizam diversos jogos eletrônicos desenvolvidos por outras empresas em seus portais. Ainda na década de 2000 surgiram aplicativos - como o Steam da empresa Valve, Origin da empresa Eletronic Arts e outros - que permitiam aos seus usuários comprarem e "baixarem" os jogos eletrônicos para computadores pessoais ( $\mathrm{pc}$ ) e consoles diretamente pela internet, eliminando a necessidade de distribuição física por meio do varejo tradicional, e diminuindo consideravelmente o preço final desses jogos. Posteriormente, surgiram também diversas outras plataformas que tornaram possível jogar em redes sociais, celulares, tablets e outros (CARDOSO, 2013).

Neste contexto, empresas com foco no desenvolvimento de jogos eletrônicos passaram a atuar no mercado global com enorme facilidade, porém passaram também a lidar com um nível de competição muito maior.

Oviatte McDougall (2005) argumentam que, para empresas que apresentam um processo de internacionalização rápido e precoce, conhecidas na literatura como Born Globals (BG), se tornarem sustentáveis, é necessário que elas desenvolvam recursos únicos, ou seja, precisam oferecer ao mercado internacional algo diferenciado, de que só elas disponham. Porém, dentro do setor de jogos eletrônicos, tal diferenciação é extremamente complexa e cara: normalmente apenas grandes empresas do setor conseguem atingi-la, oferecendo jogos de alta complexidade e custo.

A partir do exposto, esse trabalho busca investigar, por meio de dois estudos de caso, o processo de internacionalização de duas BGs brasileiras desenvolvedoras de jogos eletrônicos e as estratégias adotadas por elas que permitiram se inserirem no mercado internacional de forma sustentável.

Nesse trabalho, é utilizada uma abordagem de estudo de caso, que busca explorar novas situações de pesquisa, por meio da descrição detalhada de situações, percepções e motivações dos tomadores de decisão, assim como as decisões tomadas e suas consequências. Dessa forma, o método proporciona uma visão mais abrangente do fenômeno investigado, oferecendo novos entendimentos e conjeturas que possam servir de apoio a futuros trabalhos de cunho quantitativo. 


\section{2.}

\section{Relevância do estudo}

É crescente o interesse sobre o fenômeno BGs devido principalmente a um número cada vez maior de empresas que podem ser caracterizadas dessa forma, e pelo fato de que, apesar de a maioria das empresas ainda apresentar um processo de internacionalização incremental, a complexidade e a velocidade da internacionalização das empresas pelo mundo estão aumentando (DIB, 2008).

As teorias tradicionais sobre internacionalização de empresas (como o modelo de Uppsala e os modelos de Inovação), que datam da década de 1970, apresentam algumas lacunas, o que é evidenciado pelo surgimento das BGs também conhecidas como International New Ventures (INV) - que apresentam características contrárias a essas teorias. Novas condições tecnológicas, sociais e econômicas aparentemente geraram mudanças no processo de internacionalização, que as teorias mais tradicionais de internacionalização de empresas já não explicam com exatidão (OVIATT e MCDOUGALL, 1997).

As BGs, além de mostrarem uma internacionalização precoce, também não apresentam os estágios descritos nas teorias mais tradicionais como a de Uppsala,que previa que o processo de internacionalização deveria ser lento e gradual em termos de aprendizado e comprometimento de recursos. Tais mudanças no processo de internacionalização das empresas aparentemente podem ser explicadas pelas alterações no ambiente de negócios resultantes da globalização (DIB, ROCHA e SILVA, 2010).

Finalizando, apesar do crescente interesse com relação ao fenômeno Born Global e da relativa abundância de pesquisas sobre o tema, ele ainda é pouco pesquisado em empresas de países emergentes como o Brasil (BATAS e LIU, 2013; DIB, ROCHA e SILVA, 2010; ZOU e GHAURI, 2010).

\section{3.}

\section{Objetivos do estudo}

O objetivo deste estudo é investigar o processo de internacionalização precoce de duas empresas brasileiras de jogos eletrônicos, utilizando o método de estudo de casos, com o propósito de identificar os motivos para essas empresas buscarem o mercado exterior de forma acelerada e como elas conseguem se tornar sustentáveis em um mercado internacional tão competitivo. 


\section{4 .}

\section{Organização do estudo}

O trabalho está dividido em sete capítulos como descrito a seguir. Neste primeiro capítulo tem-se a introdução, o problema, a relevância, e os objetivos desta dissertação de mestrado.

No segundo capítulo é apresentado o referencial teórico utilizado sobre o tema da internacionalização de BGs.

No terceiro capítulo é apresentada a metodologia adotada, com a definição do método de pesquisa escolhido (o estudo de caso), assim como suas vantagens e limitações.

No quarto capítulo é apresentada uma breve análise da indústria de jogos eletrônicos no Brasil e no mundo, no quinto capítulo são apresentados os estudos de caso das empresas Aquiris Games e Manifesto Gamescom a descrição dos seus históricos, perfis dos dirigentes, processos de internacionalização, barreiras à internacionalização, facilitadores para a internacionalização e perspectivas futuras das empresas.

No sexto capítulo, é apresentada a análise dos casos, confrontando-se os dois casos estudados entre si e com a teoria examinada.

No sétimo são apresentadas as conclusões e recomendações para estudos futuros. 


\section{2 \\ Referencial teórico}

\section{1.}

\section{O fenômeno Born global}

A partir da década de 1990 assistiu-se a crescente interesse no estudo de empresas que apresentam um processo de internacionalização rápido e precoce, diferente dos processos de internacionalização de empresas tradicionais. Para tal processo de internacionalização foram dados diferentes nomes na literatura, como: high technology start-ups (JOLLY, ALAHUTHA e JEANNET, 1992), Born Globals (KNIGHT e CAVUSGIL, 1996; MADSEN e SERVAIS, 1997; RENNIE, 1993), e International New Ventures (INV) (OVIATT e McDOUGALL, 1994). Embora esses e outros nomes continuem a ser utilizados, o termo Born Global acabou por se tornar mais popular na literatura de negócios internacionais (DIB, 2008). Por esse motivo, adota-se nesse estudo o termo Born Globals (BGs) para designar esse tipo de empresa, com exceção de quando os autores se referirem especificamente à INVs.

Knight e Cavusgil (2004) definem BGs como "organizações empresariais que, próximo ao inicio de suas atividades, buscam um desempenho superior em negócios internacionais a partir da aplicação de seus recursos baseados em conhecimento para comercialização da sua produção" (KNIGHT e CAVUSGIL, 2004).

Por sua vez, Oviatt e McDougall (2004) definem Born Global como "uma organização empresarial que, desde a sua fundação, busca obter significativa vantagem competitiva através do uso de recursos e a venda da produção em múltiplos países". O que distingue essas start-ups é que suas origens são internacionais e podem ser comprovadas através do comprometimento de recursos observáveis e significativos (material, pessoas, financeiro, tempo etc.) em mais de um país. As BGs iniciam suas atividades utilizando estratégias internacionais proativas, ao contrário das empresas multinacionais tradicionais, que surgem gradualmente a partir de empresas domésticas. $O$ foco na caracterização de uma Born Global não está em seu tamanho, assim, essas empresas não necessariamente possuem ativos no exterior, ou seja, para elas 
existirem não é necessário que tenham investimentos no exterior, já que podem realizar alianças estratégicas que lhes permitam utilizar recursos de parceiros no exterior (OVIATT e MCDOUGALL, 2004).

As tradicionais teorias sobre internacionalização de empresas, como a de Uppsala e os modelos de Internacionalização como Inovação datam da década de 1970, sendo conhecidas como teorias de estágios, por considerarem o processo de internacionalização de empresas como um processo gradual e incremental, determinísticos por natureza e com dependência da trajetória (KOCAK e ABIMBOLA, 2009). Esses modelos e teorias possuem algumas lacunas, sendo a mais evidente o fato de não explicarem o surgimento de BGs, que apresentam características contrárias a essas teorias. Novas condições tecnológicas, sociais e econômicas aparentemente geraram mudanças no processo de internacionalização, de tal forma que as teorias mais tradicionais de internacionalização de empresas já não explicam o fenômeno com exatidão (OVIATT e MCDOUGALL, 1997).

A teoria de Uppsala e os modelos de Inovação afirmam que as empresas se tornam internacionais de forma lenta e gradual, e que esse processo se deve principalmente à falta de conhecimento dos mercados externos, à alta aversão a riscos, ao alto grau de incerteza, ou fatores similares. Enquanto o modelo de Uppsala é caracterizado como um aprendizado de processos organizacionais bastante demorado, os modelos de inovação tendem a analisar o processo como um caminho inovador de ações, ou seja, estão relacionado a adoção de novas formas de fazer negócios (adoção de inovações). Assim, essas teorias veem a internacionalização de empresas como um processo incremental, que envolvem um número variável de estágios (MADSEN e SERVAIS, 1997).

Na década de 1990 começaram a surgir, com maior frequência, empresas com as características das BGs, que buscam maior vantagem competitiva através do uso de recursos e das vendas em múltiplos mercados. Esse processo de crescimento do número de BGs é um sinal de que importantes dimensões no processo de internacionalização podem ter mudado desde a década de 1970, quando as principais teorias de internacionalização foram criadas (OVIATT e MCDOUGALL, 1997).

Inicialmente o fenômeno BG surgiu em países com mercados domésticos pequenos, porém atualmente essas empresas estão aparecendo em grande número pelo mundo todo (KNIGHT e CAVUSGIL, 2004). 
Madsen (2012) demonstra o crescimento do número de BGs na Dinamarca. Na Tabela 1 é possível verificar que ao mesmo tempo em que as BGs apresentaram expressivo crescimento, o surgimento de empresas que foram fundadas buscando atender apenas o mercado doméstico também diminuiu significativamente.

Tabela 1 - Classificação das Born Globals Proposta por Madsen

\begin{tabular}{l|l|l|l|l|l|l}
\hline $\begin{array}{c}\text { Ano de } \\
\text { fundação }\end{array}$ & $\begin{array}{c}\text { Born } \\
\text { Local }\end{array}$ & $\begin{array}{c}\text { Born International } \\
\text { Sourcer } \\
1981\end{array}$ & $\begin{array}{c}\text { Born } \\
\text { International } \\
\text { Seller }\end{array}$ & $\begin{array}{c}\text { Born } \\
\text { European }\end{array}$ & $\begin{array}{c}\text { Born } \\
\text { global }\end{array}$ & Total \\
\hline $1982-1991$ & $33,3 \%$ & $14,9 \%$ & $8,7 \%$ & $15,4 \%$ & $4,3 \%$ & $100 \%$ \\
\hline $1992-2001$ & $15,6 \%$ & $13,3 \%$ & $16,5 \%$ & $27,1 \%$ & $8,2 \%$ & $100 \%$ \\
\hline Total & $39 \%$ & $15,6 \%$ & $17,4 \%$ & $34,4 \%$ & $19,3 \%$ & $100 \%$ \\
\hline
\end{tabular}

Fonte: Madsen (2012, p. 74)

Apesar de as BGs terem pouca experiência internacional se comparadas a grandes multinacionais, elas possuem como vantagem competitiva uma maior flexibilidade.

A recente aceleração do processo de internacionalização e o surgimento de BGs pelo mundo evidenciam que uma nova combinação de forças está afetando o processo de internacionalização de empresas, sugerindo que a internacionalização de uma empresa não esteja ligada apenas a questões internas, e sim relacionada a todo o contexto exógeno à empresa. Em particular, grandes mudanças tecnológicas e sociais geram uma tendência de internacionalização em diversas indústrias e consequentemente nas empresas que as compõem. Nem o modelo de Uppsala nem os modelos de inovação previram esse tipo de internacionalização (OVIATT e MCDOUGALL, 1997).

\subsection{1.}

\section{Diferentes definições de Born global}

Além dos diferentes nomes dados ao fenômeno BG, ainda não existe um consenso na literatura relacionado a diversas características das BGs.

Existe um relativo consenso com relação à rápida internacionalização e ao tipo de governança das BGs. Porém ainda existem discrepâncias com relação a algumas características dessas empresas, como é o caso do grau de customização dos produtos, com alguns estudos mostrando alto grau de capacidade de customização das BGs e outros baixo (MADSEN e SERVAIS, 1997). 
Rialp, Rialp e Knight, (2005) buscaram identificar os pontos comuns e as maiores divergências em 38 estudos sobre BGs desenvolvidos entre 1993 e 2003. Foi verificado como ponto comum que a internacionalização de pequenas e médias empresas logo após seu estabelecimento constitui um novo padrão de processo de internacionalização, e que tal padrão tende a crescer. Outro ponto comum é o de que, segundo diversos autores, este novo padrão do processo de internacionalização parece inconsistente com as teorias de internacionalização tradicionais, que veem as empresas se internacionalizando de forma gradual e por etapas, como forma de diminuir riscos.

Entre as maiores discrepâncias está o fato de que, para diversos autores, o fenômeno é específico do setor de tecnologia, enquanto outros autores defendem a existência de BGs também em outros setores além do de tecnologia. Madsen e Servais (1997) ressaltam que uma possível explicação para essa discrepância é a de que as BGs originárias de países com grandes mercados internos são normalmente do setor de tecnologia, enquanto que BGs originárias de países com mercados menores tendem a ser de vários setores, pois, devido aos seus restritos mercados domésticos, necessitam expandir para outros mercados para crescerem.

Madsen (2012) por meio de uma pesquisa com aproximadamente 900 empresas dinamarquesas, verificou que o fenômeno não está restrito a empresas de tecnologia, embora esse setor apresente um número de BGs ligeiramente maior do que os outros setores estudados.

Tabela 2 - Filiação de categorias da indústria, de acordo com a classificação INV

\begin{tabular}{|c|c|c|c|c|c|c|}
\hline & $\begin{array}{l}\text { Empresas } \\
\text { domésticas }\end{array}$ & $\begin{array}{l}\text { Start-up de } \\
\text { exportação } \\
\text { /importação }\end{array}$ & $\begin{array}{l}\text { Multinacio } \\
\text { nal de } \\
\text { comércio }\end{array}$ & $\begin{array}{l}\text { Start-up } \\
\text { geografica } \\
\text { mente } \\
\text { focada }\end{array}$ & $\begin{array}{l}\text { Start-Up } \\
\text { Global }\end{array}$ & Total \\
\hline $\begin{array}{l}\text { Alimentos, } \\
\text { têxteis etc. }\end{array}$ & $28,9 \%$ & $38,8 \%$ & $26,6 \%$ & $1,1 \%$ & $4,4 \%$ & $100 \%$ \\
\hline $\begin{array}{l}\text { Química, } \\
\text { plásticos etc. }\end{array}$ & $38,3 \%$ & $42,5 \%$ & $13,2 \%$ & $3 \%$ & $3 \%$ & $100 \%$ \\
\hline Metaisetc. & $57,6 \%$ & $27,6 \%$ & $9,7 \%$ & $1,5 \%$ & $3,6 \%$ & $100 \%$ \\
\hline $\begin{array}{l}\text { Máquinas, } \\
\text { equipamentos }\end{array}$ & $33,1 \%$ & $37,4 \%$ & $19 \%$ & $1,8 \%$ & $8,6 \%$ & $100 \%$ \\
\hline Elétrica, ótica & $33 \%$ & $25,4 \%$ & $23,8 \%$ & $6,9 \%$ & $10,7 \%$ & $100 \%$ \\
\hline $\begin{array}{l}\text { Móveis, } \\
\text { transp. etc. }\end{array}$ & $43 \%$ & $35,4 \%$ & $12,9 \%$ & $2,1 \%$ & $6,5 \%$ & $100 \%$ \\
\hline $\begin{array}{l}\text { Software, } \\
\text { pesquisa }\end{array}$ & $32,1 \%$ & $28,5 \%$ & $28,5 \%$ & $3,6 \%$ & $7,1 \%$ & $100 \%$ \\
\hline Total & $40,3 \%$ & $34 \%$ & $17 \%$ & $2,8 \%$ & $6 \%$ & $100 \%$ \\
\hline
\end{tabular}

Fonte: Madsen(2012, p. 76) 
Oviatt e McDougall (1997) descrevem algumas características comuns às BGs, tais como: a necessidade de acessar alguns recursos valiosos ao menor custo possível (geralmente recursos humanos), independentemente do lugar no mundo em que esses recursos estejam; implementar a estratégia de atender um nicho global com produtos e serviços únicos; o fato de serem fundadas por empreendedores com experiência internacional e com metas agressivas de crescimento; a necessidade de ter processos organizacionais fortemente coordenados.

Oviatt e McDougall (2004) separaram as BGs (ou como chamadas pelos autores International New Ventures) em quatro tipos, como pode ser visto na Figura 1. As empresas foram divididas de acordo com o número de países em que atuavam e pela quantidade de atividades que desempenhavam na cadeia de valor. No primeiro e segundo quadrantes estão localizadas empresas importadoras e exportadoras, que podem variar bastante na quantidade de países em que atuam, mas possuem poucas atividades na cadeia de valor, assim, no primeiro quadrante está a "Start-up de exportação e importação" e no segundo quadrante está a "Comercializadora multinacional". A empresa do terceiro quadrante, "Start-up focada geograficamente", busca atender apenas determinadas regiões, mas é especializada em atender tais regiões atuando em diversas atividades. No quarto quadrante está a "Start-up global", que atua em grande número de países e desempenha diversas atividades na cadeia de valor.

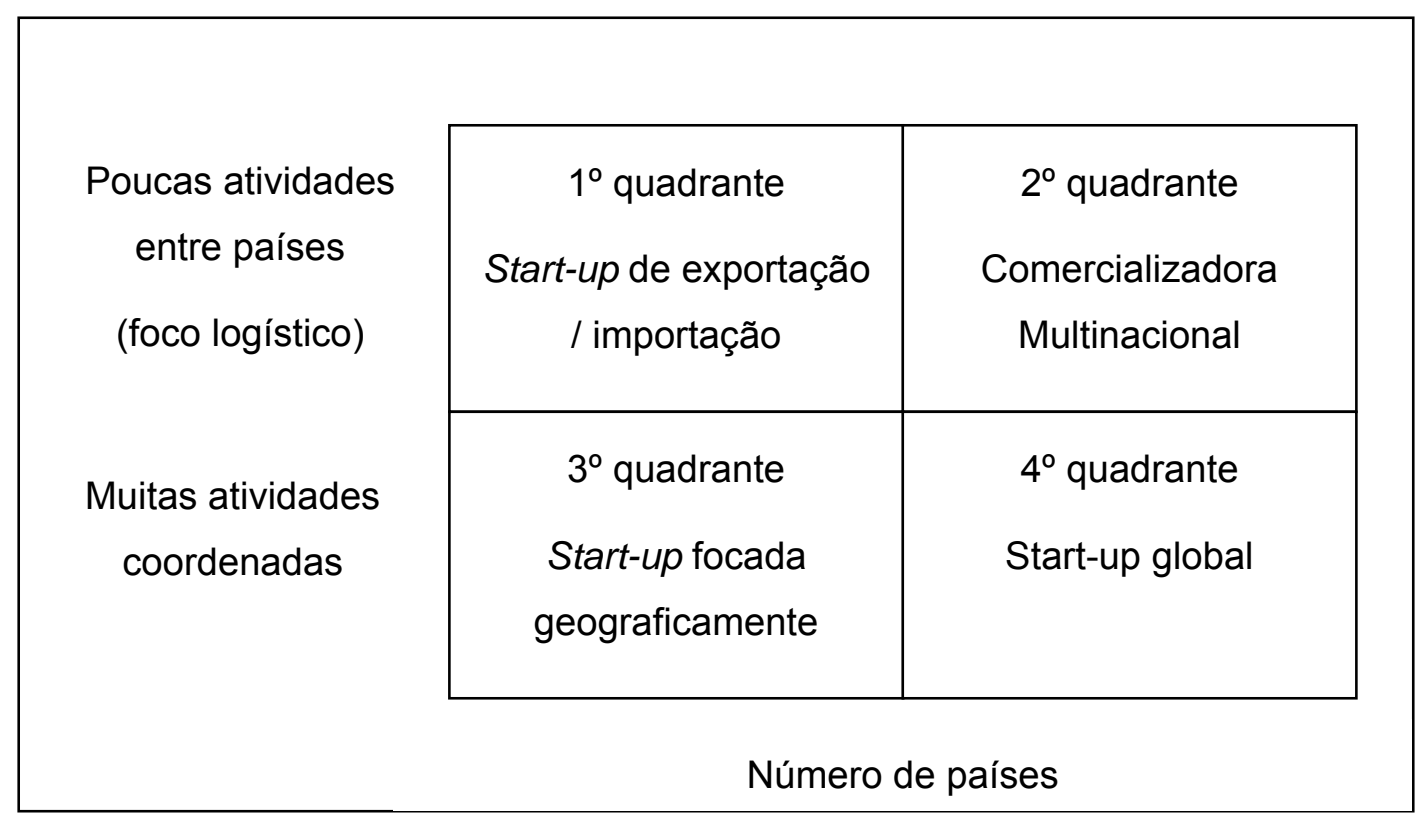

Figura 1 - Tipos de INV

Fonte: Oviatt and McDougall (2004, p. 37) 
Madsen (2012) compara as classificações de empresas que tiveram seus processos de internacionalização precoces e rápidos, utilizando para isso a literatura de INVs e deBGs.

No trabalho, enquanto o método de classificação de INVs é caracterizado por ser baseado na velocidade e no escopo da internacionalização, o método de classificação de BGs é caracterizado como sendo baseado na velocidade e na extensão da internacionalização das empresas. A velocidade de internacionalização está relacionada ao tempo entre a fundação das empresas e as primeiras vendas internacionais, o escopo está relacionado ao número de países em que são geradas as vendas e a extensão está relacionada ao percentual das vendas internacionais em relação às vendas totais da empresa. Para comparar os métodos de classificação de INVs e BGs, foram criadas subclassificações dos dois métodos, e posteriormente as empresas utilizadas nos estudos foram classificadas pelos dois métodos para que fosse possível avaliar o quão semelhante são os métodos INV e BG.

Para a classificação das BGs foram criados três níveis de vendas internacionais e de fornecimento, considerando a empresa já com três anos de existência. Os níveis de vendas internacionais podem ser zero, menos que $25 \%$ das vendas totais provenientes de fora do continente da empresa, e mais $25 \%$ das vendas totais provenientes de fora do continente da empresa. Os níveis de fornecimento também seguem o mesmo raciocínio, assim, o primeiro nível tem zero de fornecimento, o segundo menos que $25 \%$ de fornecimento estrangeiro fora do continente da empresa, e o terceiro mais de $25 \%$ de fornecimento estrangeiro fora do continente da empresa. Com a combinação de um nível de vendas e um nível de fornecimento foram criados cinco tipos de BGs, são elas: Born Local (zero de vendas e zero de fornecimento estrangeiro), Born International de Vendas (percentual positivo das vendas no exterior e zero de fornecimento estrangeiro), Born International de Fornecimento (sourcer) (percentual positivo de fornecimento estrangeiro e zero em vendas no exterior), Born Regional (no estudo, Européia) (menos de $25 \%$ das vendas no exterior e menos de $25 \%$ de fornecimento estrangeiro), e Born Global (percentual positivo das vendas no exterior e percentual positivo de fornecimento estrangeiro). $O$ Quadro 1 mostra a divisão das Born Globals com mais detalhes. 
Quadro 1 - Classificação BGpara novas empresas

\begin{tabular}{|c|c|c|c|}
\hline $\begin{array}{c}\text { Classificação de New } \\
\text { Ventures }\end{array}$ & $\begin{array}{l}\text { Sem vendas no } \\
\text { exterior nos } \\
\text { primeiros três } \\
\text { anos }\end{array}$ & $\begin{array}{l}\text { Menos que } 25 \% \text { das } \\
\text { vendas totais } \\
\text { provenientes de fora } \\
\text { do continente da } \\
\text { empresa }\end{array}$ & $\begin{array}{l}\text { Mais } 25 \% \text { das } \\
\text { vendas totais } \\
\text { provenientes de } \\
\text { fora do continente } \\
\text { da empresa }\end{array}$ \\
\hline $\begin{array}{c}\text { Sem recursos } \\
\text { estrangeiros nos } \\
\text { primeiros três anos }\end{array}$ & Born Local & $\begin{array}{c}\text { Born International de } \\
\text { Vendas }\end{array}$ & $\begin{array}{l}\text { Born International } \\
\text { de Vendas }\end{array}$ \\
\hline $\begin{array}{c}\text { Menos que } 25 \% \text { de } \\
\text { fornecimento } \\
\text { estrangeiro fora do } \\
\text { continente da empresa }\end{array}$ & $\begin{array}{c}\text { Born } \\
\text { International de } \\
\text { Fornecimento }\end{array}$ & $\begin{array}{l}\text { Born Regional (no } \\
\text { estudo, Europeia) }\end{array}$ & Born Global \\
\hline $\begin{array}{c}\text { Mais de } 25 \% \text { de } \\
\text { fornecimento } \\
\text { estrangeiro fora do } \\
\text { continente da empresa }\end{array}$ & $\begin{array}{c}\text { Born } \\
\text { International de } \\
\text { Fornecimento }\end{array}$ & Born Global & Born Global \\
\hline
\end{tabular}

Fonte: Madsen (2012, p. 71)

A mesma quantidade de categorias foi criada para a classificação de International New Ventures. Foram usados dois níveis de classificação baseados nas atividades da cadeia de valor e outros dois para classificar a quantidade de mercados internacionais explorados. Também é usado o mesmo critério de três anos de existência das empresas. Os níveis baseados na cadeia de valor são de 1 a 2 atividades e o segundo de 3 a 4 atividades. Os níveis baseados na quantidade de mercados explorados são de 1 a 3 mercados estrangeiros, e de 4 ou mais mercados. Combinando os níveis, têm-se as seguintes classificações para INVs: "Start-up de exportação/importação" (de 1 a 2 atividades e de 1 a 3 mercados estrangeiros), "Multinacional de comércio" (de 1 a 2 atividades e de 4 ou mais mercados), "Start-up geograficamente focada" (de 3 a 4 atividades e de 1 a 3 mercados estrangeiros), "Start-up Global" (de 3 a 4 atividades e de 4 ou mais mercados) e Empresa doméstica (nenhuma atividade internacional e nenhum comércio exterior). O Quadro 2 apresenta a matriz de classificação das INVs.

Quadro 2- Classificação INV de novas empresas

\begin{tabular}{|c|c|c|}
\hline $\begin{array}{c}3 \text { a } 4 \text { atividades coordenadas } \\
\text { nos primeiros três anos da } \\
\text { empresa }\end{array}$ & $\begin{array}{c}\text { Start-up } \\
\text { geograficamente focada }\end{array}$ & Start-up Global \\
\hline $\begin{array}{c}1 \text { ou } 2 \text { atividades } \\
\text { coordenadas nos primeiros } \\
\text { três anos da empresa }\end{array}$ & $\begin{array}{c}\text { Start-up de } \\
\text { exportação/importação }\end{array}$ & $\begin{array}{l}\text { Multinacional de } \\
\text { comércio }\end{array}$ \\
\hline $\begin{array}{c}\text { Empresa doméstica } \\
\text { (nenhuma atividade } \\
\text { internacional e nenhum } \\
\text { comércio exterior) }\end{array}$ & $\begin{array}{l}1 \text { a } 3 \text { mercados externos } \\
\text { explorados nos primeiros } \\
\text { três anos da empresa }\end{array}$ & $\begin{array}{c}4 \text { ou mais mercados } \\
\text { externos explorados nos } \\
\text { primeiros três anos da } \\
\text { empresa }\end{array}$ \\
\hline
\end{tabular}

Fonte: Madsen (2012, p. 71) 
O trabalho, por meio de uma pesquisa com aproximadamente 900 empresas, verificou que os dois métodos de classificação produzem resultados semelhantes quando relacionados aos padrões de internacionalização, porém podem apresentar resultados bastante diferentes quando utilizados para classificar empresas de forma individualizada. Assim, o autor recomenda que as empresas devam ser analisadas por meio das três dimensões: tempo, escopo e extensão.

Jones, Coviello e Tang (2011) consideram que a definição de BG não está precisa e que seria necessário colocar a intenção da empresa em se internacionalizar, ou seja, empresas que se internacionalizam precocemente, segundo a visão dos autores, só poderiam ser consideradas BGs se buscassem intencionalmente a internacionalização.

\subsection{2.}

\section{Características de Born Globals}

Dib (2008) desenvolveu uma lista, com base na literatura, com as principais características de uma Born global. São elas:

$>$ ter suas atividades globais iniciadas com até 3 anos (porém, para empresas brasileiras, devido às dificuldades enfrentadas por elas no processo de internacionalização, são considerados até 5 anos);

ter pelo menos $25 \%$ de suas vendas totais oriundas de atividades internacionais, podendo variar bastante entre indústrias;

ter um modo de entrada flexível, porém tipicamente ativo;

$>$ quanto maior o número de atividades da cadeia de valor, mais a empresa tenderia a ser uma BG;

> quanto mais abrangente geograficamente, mais a empresa tenderia a ser uma BG;

$>$ as motivações para internacionalização de uma BG deveriam ser mais ligadas a uma estratégia clara e proativa, que buscasse uma posição de destaque em mercados de nicho globais;

quanto maior a dispersão da atuação da empresa em seu mercado local, maior deveria ser sua propensão em se internacionalizar.

Apesar de já existir relativo consenso em relação às características de uma Born global, ainda existem alguns problemas na literatura com relação à escolha dessas características, que são abordadas a seguir. 


\section{- Data de fundação ou estabelecimento da empresa}

Descobrir a data exata da fundação de uma empresa não é uma tarefa fácil, uma vez que o processo de formação da empresa é um processo evolutivo, que começa na idéia inicial de abertura da empresa, passa por várias etapas e termina talvez com a criação de uma pessoa jurídica. Desse modo, utilizar uma data exata de criação de empresa pode ser um procedimento um tanto ambíguo (MADSEN, 2012).

Oviatt e McDougall (2004) consideram que uma empresa está estabelecida quando é possível verificar o comprometimento de recursos observáveis. Já Madsen e Servais (1997) argumentam que a perspectiva de tempo de BGs deveria ser estendida para antes do seu nascimento, pois muitas das suas características essenciais foram adquiridas em experiências prévias de seus fundadores. Observam ainda que, em muitos casos, o "nascimento" de uma BG pode ser duvidoso, pois apesar do fato de a empresa ser nova, frequentemente já possui uma considerável maturidade.

\section{- Início das atividades internacionais}

Há ainda uma grande divergência entre os pesquisadores em relação ao número máximo de anos entre a fundação da empresa e o início das atividades internacionais, podendo variar de dois anos (MOEN e SERVAIS, 2002; MOEN, 2002) até 15 anos (GABRIELSSON, SASI e DARLING, 2004).

\section{- Relevância das atividades internacionais para a empresa}

Outro ponto de grande divergência existente em diversas pesquisas é o percentual mínimo de faturamento proveniente das atividades internacionais para que uma empresa possa ser considerada uma BG, podendo variar de mais de 5\% (MCDOUGALL, 1989) até mais de 75\% (CHETTY e CAMPBELL-HUNT, 2004).

\section{- Abrangência geográfica da internacionalização}

Oviatt e McDougall (2004) utilizou o número de países como forma de classificar as INVs. Já Madsen (2012) usou um modelo mais detalhado, com clara delimitação entre as categorias de INVs e a quantidade de países que são explorados por elas. Mcnaughton (2003) verificou também que o número de mercados em que uma Born Global atua pode estar relacionado com o tamanho do seu mercado doméstico: quanto menor o mercado doméstico, maiores as chances de a empresa atuar em vários países. Pode estar relacionado também à capitalização de oportunidades em mercados internacionalizados e à apropriação dos benefícios de produtos baseados em conhecimento. Já Lopez, 
Kundu e Ciravegna (2008) desenvolveram um estudo com pequenas empresas de software, que mostrou que o conceito de BG pode esconder algumas diferenças importantes entre as empresas. Em sua opinião, diversas BGs deveriam ser classificadas como Born Regionals, pois tais empresas buscam exportar apenas para mercados regionais, e não para diversas regiões do planeta.

\section{- Escopo das atividades internacionais}

Para Oviatt e McDougall (2004), uma importante variável para classificação das INVs é a coordenação da cadeia de atividades internacionais das empresas. Este conceito foi operacionalizado na pesquisa verificando se as empresas coordenavam as seguintes atividades no exterior após três anos de sua fundação: atividades de fornecimento (matéria-prima, componentes, equipamentos de produção, ou processos), de produção, de vendas e marketing, e atividades de serviços (instalação manutenção, reparo, treinamento etc.).

Para Madsen (2012), se uma empresa coordena 1 ou 2 atividades internacionais da cadeia de valor dentro de três anos após sua fundação, ela é classificada como menos internacional, e se uma empresa tem 3 ou 4 atividades é classificada como mais internacional.

\subsection{3.}

\section{Determinantes do processo de internacionalização Born global}

\subsubsection{1. Influência das tendências globais}

Oviatt e McDougall (2005) consideram que o desenvolvimento tecnológico foi o fator que permitiu a rápida internacionalização de empresas, uma vez que, o que na década de 1970 era muito caro ou impossível de ser feito, passou a ser rotineiro e barato. Segundo os autores, os principais avanços tecnológicos que permitiram o surgimento de BGs foram: (i) os avanços no transporte internacional, que permitiram às pessoas viajarem de forma mais barata, maiores distâncias, e em menos tempo, e que uma grande variedade de produtos pudesse ser transportada por diversos modais que também tiveram seus custos drasticamente reduzidos, além de ficarem mais rápidos e eficientes; (ii) os avanços e a queda nos custos de equipamentos digitais; e (iii) os avanços na área da comunicação, que permitiram, por exemplo, a comunicação instantânea entre pessoas ao redor do mundo através da internet, com um custo próximo de zero. 
Para Knight e Cavusgil (2004), o surgimento de BGs está baseado na globalização e nos avanços tecnológicos que possibilitaram a redução dos custos das transações internacionais significativamente. Os diversos avanços tecnológicos nas áreas de tecnologia da informação, comunicação, métodos de produção, transporte e logística internacional, permitiram a redução dos custos de transações comerciais, e consequentemente facilitaram enormemente o crescimento do comércio internacional. A ampla difusão da internet e tecnologias relacionadas tornou a internacionalização uma opção mais viável e rentável. Já a globalização permitiu a simplificação do desenvolvimento de produtos e posicionamento em mercados internacionais por meio do aumento da homogeneização das preferências dos consumidores no mundo.

Bloodgood, Sapienza e Almeida (1996) estudou o processo de internacionalização de 61 empresas americanas. Os pesquisadores argumentam que uma empresa nova irá buscar se internacionalizar basicamente por dois motivos. O primeiro motivo é quando a indústria na qual está inserida de certa forma exige a presença internacional da empresa. O segundo motivo ocorre quando empresas possuem recursos únicos e buscam se internacionalizar como forma de capitalizar tais recursos.

Para Madsen e Servais (1997), o aparecimento de BGs se deve a pelo menos três fatores: novas condições de mercado; desenvolvimentos tecnológicos nas áreas de produção, transporte e comunicação; e aumento da capacitação dos trabalhadores, incluindo os fundadores das BGs. Entre os fatores relacionados às novas condições de mercado estão: a crescente especialização das empresas, e consequente aumento no número de nichos de mercado; aparecimento de mais empresas focadas na produção de peças e componentes específicos, para atender mercados internacionais, pois qualquer mercado passa a ser pequeno demais para tais peças e componentes tão específicos; homogeneização das necessidades e desejos dos compradores pelo mundo; novas tecnologias de processo de produção, que tornaram as produções em pequena escala economicamente viáveis; e o transporte de pessoas e bens tornou-se mais confiável, frequente e barato, o que pode ser traduzido em menores barreiras de custo para uma expansão internacional. Entre os fatores relacionados à área de comunicação estão: o baixo custo com a utilização de equipamentos de informática que permitem o controle de operações internacionais das empresas; e também a utilização desses equipamentos para recolher, analisar e interpretar informações do mercado 
internacional. Entre os fatores relacionados ao aumento da capacidade de recursos humanos encontram-se: o aumento drástico do número de pessoas com experiência internacional ao longo das últimas décadas; e o aumento do número de potenciais empregados com competência para se comunicar, entender e operar em culturas estrangeiras.

$O$ interesse no desenvolvimento de tecnologias que permitam às empresas se internacionalizarem de forma cada vez mais eficiente tem sido crescente. $A$ internet e a tecnologia da informação estão alterando permanentemente o cenário do comércio internacional. É neste contexto de alta tecnologia para internacionalização, que pequenas empresas estão surgindo, sem o fardo de heranças administrativas, e desempenhando um papel cada vez maior dentro do mercado internacional (KNIGHT E CAVUSGIL, 2004).

\subsubsection{2.}

\section{Influência da internet}

Sinkovics, Sinkovics e Jean(2013) apresentam um framework conceitual para analisar antecedentes e desempenho de dois padrões de utilização da internet para auxiliar a exportação em pequenas e médias empresas: o uso da internet como alternativa à presença física da empresa em mercados externos, e o uso da internet como canal de vendas em mercados externos. $O$ trabalho também examina $\mathrm{O}$ fracasso de empresas que possuem um alto comprometimento com a internacionalização online, e acabam generalizando seus conhecimentos sobre os mercados, não analisando plenamente as complexidades dos seus clientes, e consequentemente mantendo distância física e relacional desses mercados externos, levando a um baixo desempenho internacional. Por último, o estudo compara o papel da internet no processo de internacionalização de BGs e outras empresas exportadoras tradicionais.

No framework desenvolvido são verificadas as seguintes relações:

$>\mathrm{O}$ uso da internet como forma de reduzir barreiras psíquicas quando empresas tentam entrar em mercados muito diferentes dos delas;

A influência do uso da internet, ao invés da presença física da empresa, e o uso da internet como canal de vendas no desempenho das exportações;

A influência da redução de barreiras de exportação, da capacidade de resposta aos mercados, dos fatores de risco e incertezas em mercados turbulentos, do alcance e conquista de novos clientes na internacionalização online ao invés da presença física; 
A influência da orientação empreendedora da empresa (que se refere ao comportamento proativo, disposição a correr riscos e grau de inovação) no uso da internet como canal de vendas.

A pesquisa encontrou evidências de que o uso da internet por empresas domésticas ou por pequenas, médias e grandes empresas internacionalizadas pode proporcionar grandes oportunidades para essas empresas alavancarem suas capacidades de processamento de informações e conectividade global, além de aprimoramento de processos de negócios e aumento de suas vantagens competitivas.

O uso de canais de vendas online tende a melhorar o desempenho nas exportações de pequenas e médias empresas. No entanto, o uso da internet como alternativa para utilização da presença física da empresa em mercados externos não necessariamente leva a melhor desempenho nas exportações, pois pode fazer com que a empresa exportadora perca interações pessoais com seus clientes e também conhecimentos específicos dos mercados de interesse. Devido à falta de recursos, as BGs tendem a utilizar a internet como forma de substituir a presença física e, consequentemente, acabam sofrendo mais com os efeitos negativos deste tipo de internacionalização.

O estudo não encontrou evidências da diminuição das barreiras psíquicas por meio do uso da internet, com exceção das BGs que mostraram acreditar na internet como forma de reduzir suas barreiras de exportação.

A capacidade de resposta aos mercados e o alcance e conquista de novos clientes se mostraram positivamente relacionados à utilização da internet ao invés da presença física, porém ao contrário do esperado pelos autores, os fatores de risco e incertezas em mercados turbulentos ficaram negativamente relacionados à utilização da internet ao invés da presença física.

Com relação à orientação empreendedora, ela se mostrou positivamente relacionada à utilização da internet como canal de vendas.

Por fim, no estudo foi evidenciado também que empresas com diferentes processos de internacionalização podem apresentar algumas diferenças, tais como: BGs tendem a adotar mais a internet como forma de exportação, inclusive utilizando a internet como forma de substituir a presença física. Já empresas exportadoras mais tradicionais tendem a utilizar a internet apenas como forma complementar de atuação em mercados externos. 


\subsubsection{3.}

\section{Influência dos fatores ambientais do País}

Gabrielsson (2005) estudou as estratégias de marca de 30 BGs finlandesas, verificando que em todos os casos as empresas sentiram a necessidade de buscar novos mercados, pois o mercado finlandês se mostrou pequeno demais para tais empresas.

Bloodgood, Sapienza e Almeida (1996), por meio de um estudo sobre o processo de internacionalização de 61 empresas americanas, evidenciaram como fatores ambientais podem afetar as BGs, eles explicam que nos EUA é menos comum a existência de BGs do que em outras regiões do mundo, como a Europa, onde novas empresas tem maior tendência em se internacionalizar, pois enquanto que uma empresa americana opera em raio de 800 quilômetros sem que ultrapasse as barreiras do seu país, uma empresa européia para operar os mesmos 800 quilômetros terá que lidar com 5 ou 6 países. As empresas americanas além de possuírem um vasto território para atender, também servem um dos maiores mercados do mundo, e, além disso, não costumam participar tanto de redes de fornecedores como as empresas européias e japonesas.

Outra razão para os EUA terem menor número de BGs do que países europeus e o Japão, no período analisado, foi atribuído pelo autor ao menor apoio do governo americano a pequenas e médias empresas, que, se comparado ao governo japonês, pode chegar a até 20 vezes menos em relação a ajuda financeira. Em países europeus, os governos financiam centros de pesquisa e desenvolvimento e fornecem serviços de previsão de mercado para pequenas empresas. Dessa forma, pequenas e médias empresas japonesas e européias pareciam mais inclinadas para a internacionalização que as americanas (BLOODGOOD, SAPIENZA e ALMEIDA, 1996).

O caso do Brasil também se assemelha em alguns aspectos ao dos EUA, como evidenciado por Dib, Rocha e Silva (2010). O Brasil é um país de dimensões continentais e isolado dentro de suas fronteiras. Os únicos contatos diretos (sem barreiras naturais) ocorrem com países vizinhos ao sul, Uruguai e Argentina. Além disso, o país não desfruta de posição significativa como exportador de produtos industrializados ou de alta tecnologia, e sua tradição nas exportações se resume acommodities agrícolas e de mineração. 


\subsubsection{4.}

\section{Influência dos fatores específicos da indústria}

Um dos principais fatores que influenciam o surgimento de BGs é a necessidade da indústria na qual a empresa está inserida ter uma presença internacional, como no caso de clientes que exigem características mais globais de seus fornecedores. Isso ocorre no caso de grandes multinacionais que criam parcerias com pequenas e médias empresas e por meio dessas parcerias induzem a internacionalização das mesmas (GABRIELSSON e MANEK KIRPALANI, 2004).

Indústrias integradas internacionalmente necessitam de empresas que tenham condições de agir rapidamente para garantir um desempenho satisfatório ou até mesmo a sobrevivência (OVIATT e MCDOUGALL, 1997). Oviatt e McDougall (2005) colocam as influências ambientais, as condições favoráveis da indústria, e a pró-atividade dos empreendedores como sendo os principais fatores que determinam a velocidade de internacionalização de uma empresa.

Por sua vez, Zou e Ghauri (2010) evidenciam como a indústria pode influenciar a internacionalização de pequenas empresas, e também ser influenciada pelo governo. O estudo relata uma série de políticas que foram formuladas para promover o desenvolvimento da indústria da informação na China, com o objetivo de aumentar a capacidade de inovação e sua competitividade internacional. As políticas para estimular o desenvolvimento da indústria de software e circuitos integrados são um exemplo disso, ao buscarem simplificar os procedimentos para importação e exportação, e funcionam como forma de promover a internacionalização de empresas da indústria da informação chinesa.

Madsen e Servais (1997) colocam que o mercado doméstico de uma BG encontra-se ligado a uma capacidade específica desse tipo de empresa, que pode ser utilizada para atender a toda a indústria global em que ela está inserida.

\subsubsection{5.}

Influência dos fatores específicos da empresa e a utilização de redes de relacionamento

Knight, Madsen e Servais (2004) relataram que o menor tamanho, típico de empresas jovens, parece conferir maior flexibilidade para elas, e que tal flexibilidade proporciona benefícios fundamentais para que seja possível obter sucesso no exterior. 
Silva e Dib (2011) desenvolveram uma lista, com base na literatura, das principais características de empresas que ajudam a explicar a velocidade do processo de internacionalização, que são: organização flexível e de rápida resposta, existência de ativos singulares, estratégia de nicho, diferenciação de produtos, uso intensivo de tecnologia da informação. Foi feita também uma análise, a partir da literatura, dos principais fatores ligados a redes de relacionamento que influenciam a velocidade do processo de internacionalização, tais como: uso intensivo de parcerias com outras empresas, integração a redes de negócio internacionais, utilização de redes pessoais como facilitador na internacionalização, e inserção em clusters.

A criação de redes de relacionamento internacionais por uma empresa é considerada por diversos autores como uma das principais competências necessárias para a internacionalização da mesma. Sharma e Blomstermo (2003) propõem que modelos que se baseiam em conhecimento e em redes são apropriados para explicar o processo de internacionalização de BGs. Os laços criados com empresas internacionais podem fornecer informações relevantes sobre clientes e mercados, enquanto que empresas que criam uma rede de relacionamentos doméstica têm mais dificuldade para se internacionalizarem. No trabalho é constatado que BGs são empresas baseadas na utilização intensiva de conhecimento, vendendo produtos e serviços que podem ser totalmente novos ou extremamente diferentes dos produtos e serviços já existentes, ou seja, suas vantagens competitivas estão baseadas em seu uso intensivo de conhecimento. BGs estão envolvidas em inúmeros laços (relacionamentos) fracos com outras empresas. Esses laços fracos apresentam algumas vantagens em relação aos laços mais fortes, pois são menos complicados, menos custosos, e permitem um maior desacoplamento entre as empresas, tornando-as mais adaptáveis. Os laços fracos das BGs também permitem que essas empresas desenvolvam mais facilmente conhecimentos internacionais e adquiram maior capacidade de absorção de sinais provenientes de mercados externos.

Gabrielsson e Manek Kirpalani (2004) analisam os laços entre BGs e grandes multinacionais, cujas grandes multinacionais atuam como integradores de sistemas ou distribuidores para produtos e serviços de BGs. No trabalho são analisados os canais de distribuição necessários para que BGs possam distribuir seus produtos e serviços internacionalmente. Cinco formas de distribuição são destacadas: Multinacionais como sistemas integradores, Multinacionais 
distribuindo produtos e serviços de BGs, Redes (Networks), Internet, e uma combinação de dois ou mais desses canais.

Devido à diminuição dos custos de interação entre empresas e o alto desenvolvimento das tecnologias de informação e comunicação, As multinacionais estão cada vez mais terceirizando sua fabricação de produtos e/ou serviços. Para isso estão investindo na retenção de seus parceiros por meio de financiamentos de negócios com BGs, treinamento de pessoal, e criando contratos de longo prazo com seus fornecedores. Porém, para uma multinacional criar uma parceria com uma BG, ela precisa, entre outras coisas, apresentar diferenciais de localização, tecnologia de processos, ou um conjunto de habilidades que seriam difíceis para a multinacional adquirir. Além disso, diversas multinacionais buscam parcerias com pequenas e médias empresas que tenham condições de atuarem na complementação ou suplementação de suas linhas de produtos e serviços.

Apesar das vantagens existentes para BGs na criação de parcerias com multinacionais, existem também algumas desvantagens, pois as multinacionais normalmente buscam descontos por grandes volumes de compras. Tais descontos podem não deixar excedentes que permitam que as BGs reinvistam e desenvolvam suas competências e capacidades, e desse modo tendam futuramente a diminuírem suas taxas de crescimento.

Quando uma BG não possui recursos suficientes para desenvolver sua própria marca, ela deve buscar parcerias com canais de marketing de grande porte, uma vez que esses parceiros podem também funcionar como canais de distribuição.

As multinacionais podem atuar também como parceiros de BGs. Neste caso, as redes de relacionamento podem funcionar como meio para as BGs superarem a falta de recursos e também como fonte de aprendizado. $O$ crescimento internacional de uma BG é derivado de suas habilidades em construir e alavancar relações com seus principais clientes de suas redes de relacionamentos. Grandes multinacionais atualmente buscam expandir suas redes de atuação, operando em toda a cadeia de produção de seus produtos e serviços, assim, essas empresas necessitam de uma grande quantidade de parceiros, e as BGs com habilidades específicas podem funcionar para esse propósito. As multinacionais são geralmente mais importantes que a internet como canal de vendas para uma BG, pois a confiança de clientes que utilizam comércio eletrônico raramente é conquistada sem marcas reconhecidas como as 
de grandes multinacionais. Porém, apesar da maior importância das multinacionais, a internet também se mostrou bastante útil como meio para contornar a falta de recursos para comercialização de produtos e serviços de BGs, principalmente quando combinada com o apoio de networks com multinacionais.

\subsubsection{6.}

\section{Influência dos fatores individuais do empreendedor}

Silva e Dib (2011) listam, com base na literatura, as características do empreendedor que podem influenciar a velocidade do processo de internacionalização de empresas: orientação e experiência internacional, maior tolerância a risco e conhecimento técnico/científico único.

Oviatt e McDougall (2005) criaram um modelo das influências na velocidade do empreendedorismo internacional, em que três fatores são responsáveis pela percepção do empreendedor a respeito do reconhecimento de uma oportunidade: os fatores tecnológicos que tornam viável o empreendedorismo, a oportunidade em si, e a concorrência que funciona como um fator motivador. Depois, para determinar a velocidade do empreendedorismo internacional, dois fatores moderadores atuam entre a percepção do empreendedor e a velocidade de internacionalização, estando o primeiro relacionado aos conhecimentos (know-how) do empreendedor e aos conhecimentos específicos da oportunidade, e o segundo fator são as redes de contatos (networks) internacionais. A Figura 2 apresenta o modelo de forças influenciando a velocidade de internacionalização, de Oviatt e McDougall (2005). 


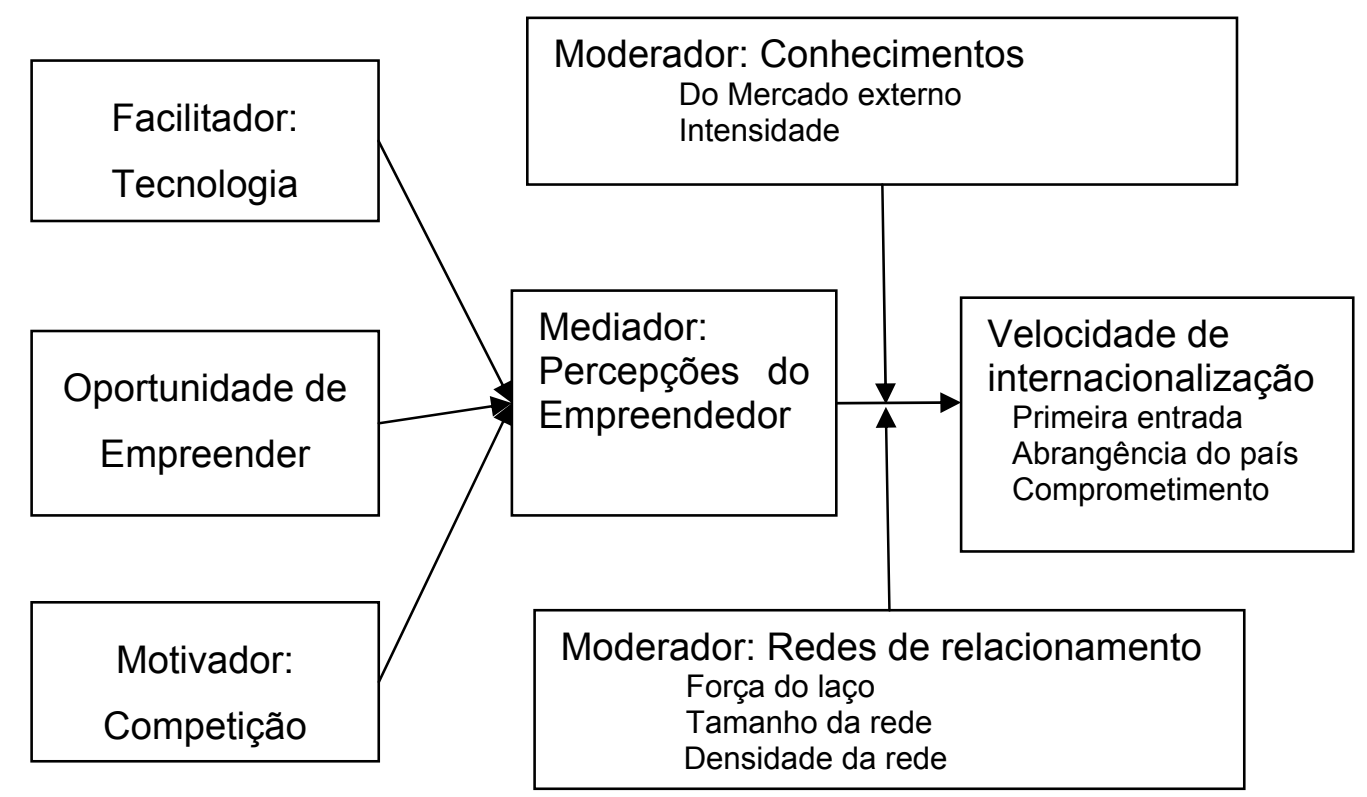

Figura 2 - Modelo de Forças que Influenciam a Velocidade da Internacionalização Fonte: Oviatt e McDougall (2005, p. 541)

Apesar de as teorias tradicionais de internacionalização de empresas, como a de Uppsala, não explicarem o comportamento das BGs, é possível verificar que, em alguns casos, as empresas se internacionalizam logo no início da sua existência devido à experiência prévia de seus fundadores (tomadores de decisão). Nestes casos, os modelos de internacionalização baseados em inserção gradativa em mercados externos, como forma de reduzir incertezas, não se aplicam, pois os tomadores de decisão dessas BGs já possuem toda a experiência necessária no mercado externo (MADSEN e SERVAIS, 1997).

\subsection{4.}

\section{Sustentabilidade de Born Global}

Em seu trabalho seminal, Oviatt e McDougall (2004) desenvolveram um framework que explica o fenômeno BG (ou INV), conforme Figura 3. 


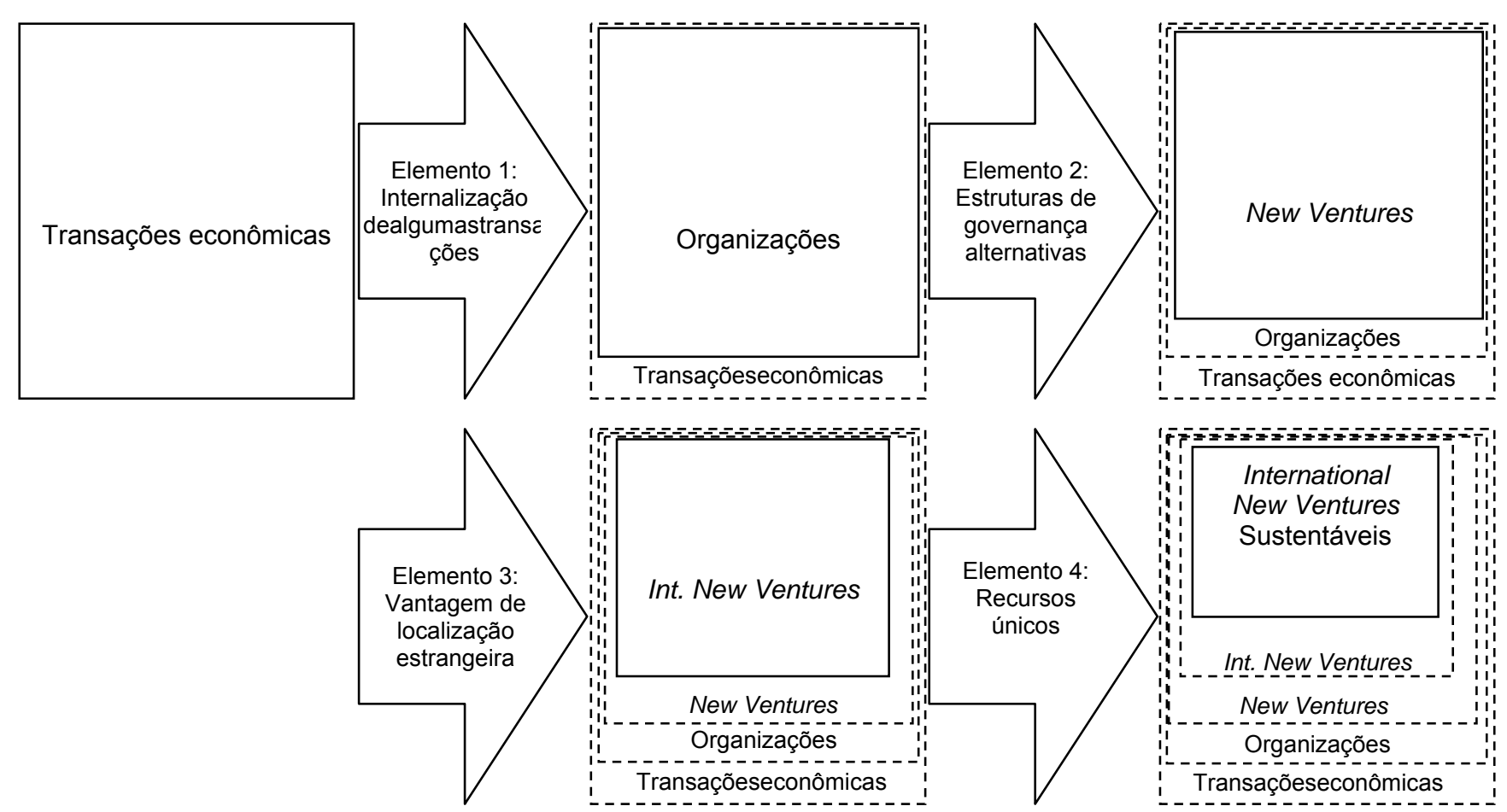

Figura 3 - Elementos necessários e suficientes para INVSustentável Fonte:Oviatt e McDougall (2004, p. 34) 
O modelo é composto por caixas, que representam um conjunto de transações econômicas, e setas, que representam elementos que fazem distinção entre uma caixa e outra. O framework começa na parte superior esquerda da figura e avança no sentido das setas. Cada caixa representa um subgrupo do conjunto de transações da caixa anterior, sendo a primeira caixa o conjunto de todas as transações econômicas existentes.

O primeiro elemento representa a internalização de algumas transações; é nele que estão definidas todas as organizações, sejam elas antigas ou novas, e domésticas ou internacionalizadas.

O segundo elemento representa as formas de governanças alternativas. As INVs normalmente não possuem recursos suficientes para obter e controlar todos os ativos de que necessitam, e desse modo buscam internalizar apenas os recursos mais essenciais para sua existência. Para contornar a falta de recursos, essas empresas necessitam de formas alternativas para controlar seus ativos, e tais formas as diferenciam das outras organizações. Entre as formas de contornar a falta de recursos existem as estruturas híbridas como licenças, franquias e redes. As últimas parecem ser mais fortes, em que os envolvidos dependem mais de controles sociais informais, baseados na confiança e na moral, ao invés de contratos formais (OVIATT e MCDOUGALL, 2004). Os resultados obtidos por Knight e Cavusgil (2004) revelaram que BGs alavancam uma combinação diferenciada de orientações e estratégias que lhes permitem ter sucesso em diversos mercados internacionais. Empresas com recursos restritos e que se estabelecem a partir de características inovadoras elaboram determinados tipos de conhecimentos e capacidades que se incorporam à cultura da organização.

O terceiro elemento representa a vantagem de localização estrangeira, que distingue as organizações domésticas das internacionais. Uma empresa decide se internacionalizar quando considera que transferir recursos móveis para um país estrangeiro irá lhe trazer vantagens. No entanto, podem também existir algumas desvantagens como barreiras governamentais ao comércio, pouco conhecimento das leis e de práticas de negócios no país estrangeiro, e a língua, que não são problemas para as empresas da região. A propriedade que mais traz vantagens competitivas para essas empresas é o conhecimento, com a atual mobilidade de conhecimento através dos novos meios de comunicação é possível a fácil reprodução de conhecimentos de alto valor e a transferência de informação de uma região para outra do outro lado do mundo de forma 
praticamente instantânea e com custo muito baixo. Por meio do conhecimento as INVs podem superar as vantagens das empresas locais em diversas regiões no mundo simultaneamente. Provavelmente é por causa da atual possibilidade da rápida transferência de conhecimento que pequenas empresas que possuem conhecimentos valiosos optam por um rápido processo de internacionalização ao invés de seguir os modelos de internacionalização mais tradicionais baseados em etapas. Porém, empresas concorrentes em diversos mercados irão buscar alternativas para a produção de conhecimentos semelhantes, acelerando desse modo todo o processo competitivo (OVIATT e MCDOUGALL, 2004).

Para Knight e Cavusgil (2004) o que distingue as BGs das outras empresas é seu foco e o comprometimento de recursos específicos em atividades internacionais. ABG, desde sua fundação, cria uma visão global dos seus mercados e desenvolve capacidades necessárias para alcançar seus objetivos internacionais. Já uma empresa que segue padrões tradicionais de internacionalização tende a desenvolver suas atividades no mercado doméstico por muitos anos, e só então gradualmente se envolve em atividades internacionais. Para os autores, a orientação empreendedora internacional e a orientação de marketing internacional são consideradas os dois atributos mais importantes dentro da cultura organizacional de uma BG. Uma orientação empreendedora pode ser descrita como a busca por mercados internacionais por meio de competências empreendedoras e perspectivas únicas. Empresas que possuem recursos limitados e buscam novas oportunidades em mercados complexos têm que lidar com incertezas e risco e por isso devem ter uma postura mais inovadora, visionária e proativa. Assim, uma orientação empreendedora internacional reflete o nível geral de inovação e a pró-atividade de uma empresa na busca de mercados internacionais. Já a orientação para o marketing internacional foi descrita como "uma mentalidade gerencial que enfatiza a criação de valor, por meio de elementos-chave de marketing, para clientes estrangeiros" (KNIGHT e CAVUSGIL, 2004). Assim o desejo contínuo de prover mais valor para o cliente e de conseguir melhor desempenho levam as BGs a criarem e manterem uma cultura que promova os comportamentos empresariais necessários.

O quarto elemento são os recursos únicos, que irão gerar a sustentabilidade para as empresas (OVIATT E MCDOUGALL, 2004). 
Para Knight e Cavusgil (2004), o desenvolvimento de produtos únicos se assemelha à estratégia de diferenciação, que envolve a criação de lealdade do cliente, atendendo uma necessidade particular. Esta abordagem é associada a fatores que distinguem a empresa dos seus competidores, tais como: patentes, serviços ao consumidor de alto nível, produtos com recursos inovadores. A utilização de conhecimentos para promover o desenvolvimento de produtos únicos também permite que BGs atendam melhor determinados nichos de mercado e, dessa forma, proporciona um aumento na participação de mercado e o crescimento de vendas. Empresas menores, com recursos limitados e com mais orientação para o mercado têm maior propensão a adotar estratégias de diferenciação de seus produtos e serviços, o que favorece um desempenho superior.

INVs baseadas em conhecimento, ao mesmo tempo em que se beneficiam da facilidade de reproduzir e transferir conhecimento, sofrem pela fácil disseminação do mesmo, que passa a ser mais facilmente copiável por outras organizações. Para evitar a imitação ou retardar o desenvolvimento de substitutos, as empresas podem limitar o uso de seus conhecimentos de quatro formas (OVIATT e MCDOUGALL, 2004). A primeira é por meio do uso de patentes, direitos autorais ou manutenção de segredo comercial. Porém, em alguns países, patentes e direitos autorais tendem a ser ignorados, assim, se o conhecimento tiver valor comercial, a melhor alternativa das três seria mantê-lo como um segredo comercial. A segunda é a criação de artifícios para fazer com que seus concorrentes não consigam imitá-la perfeitamente, por meio do uso da história da empresa, por exemplo. A terceira é o licenciamento, em que são pagas taxas para a empresa pela utilização do conhecimento. Essa forma é utilizada quando se espera que o conhecimento seja mantido pela empresa por um longo período. O uso de estratégias de baixo custo deve ser utilizado como forma de desencorajamento de concorrentes, porém, quando a demanda pelo conhecimento é alta e se espera uma vida útil pequena para o mesmo, então devem ser cobradas altas taxas sobre o conhecimento para obter o máximo de rentabilidade possível. A quarta forma envolve a questão da governança corporativa, quando são feitas alianças com outras empresas para compartilhar custos, mas também surgem riscos relativos à apropriação do conhecimento pelos parceiros. Nesse caso, porém, normalmente a própria estrutura de rede tende a controlar tais riscos. 
Knight e Cavusgil(2004) analisam mais três estratégias, além da criação de produtos únicos, como forma de BGs se manterem sustentáveis: competência técnica mundial, foco na qualidade, e aproveitamento das competências de distribuidores estrangeiros. A competência técnica mundial refere-se à capacidade tecnológica de uma empresa relativamente às empresas similares na mesma indústria. Essa competência facilita a criação de produtos superiores, a melhoria de produtos existentes, e o aumento da efetividade dos processos produtivos. Empresas líderes mundiais em tecnologia costumam interagir melhor com seus parceiros e clientes, a partir da utilização de tecnologias da informação e comunicação, com o objetivo de obter informações que as levem a obter vantagens. O foco na qualidade refere-se aos esforços da empresa em desenvolver produtos e serviços que excedam as expectativas dos clientes em relação aos recursos e desempenho prometidos. $O$ foco na qualidade implica processos inovadores e pode ser uma forma de diferenciar seus produtos e serviços dos competidores. O aproveitamento das competências de distribuidores estrangeiros refere-se à confiança nesses distribuidores e em suas competências específicas com o objetivo de maximizar os resultados de desempenho associados com as atividades internacionais. Assim, a incerteza, os riscos e os desafios presentes em mercados externos podem ser superados com a utilização do conhecimento de mercado e competências de intermediários estrangeiros. BGs, devido a sua limitação de recursos, tendem a utilizar a exportação como principal modo de entrada. Dessa forma, o uso de distribuidores internacionais pode facilitar a tarefa. Empresas com forte orientação para o marketing também tendem a procurar intermediários estrangeiros competentes, pois suas capacidades de distribuição podem facilitar a promoção da empresa, a gestão de relacionamento com clientes e outras atividades de marketing subsequentes.

Kocak e Abimbola (2009) buscam identificar recursos e capacidades que facilitam a internacionalização precoce de empresas, quando uma BG consegue obter vantagens competitivas internacionais sustentáveis em termos de desempenho. Os autores criaram um modelo para entender os principais fatores que influenciam o desempenho de uma BG (Figura 4). 


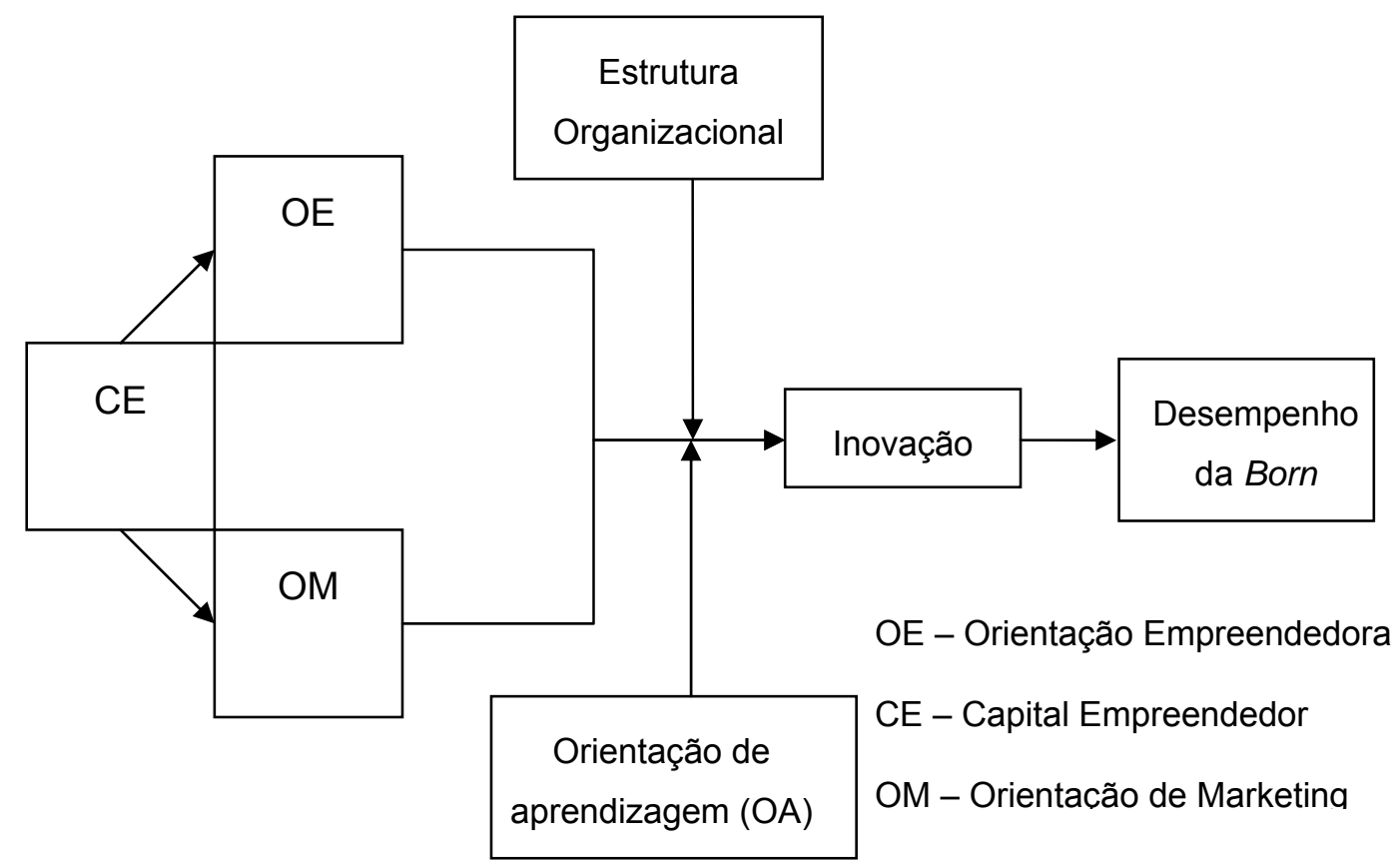

Figura 4 - Modelo conceitual da influência dos fatores do empreendedorismo de marketing no desempenho de BGs.

Fonte: Kocak e Abimbola (2009, p. 445)

O modelo associa o capital empreendedor (CE) à orientação de marketing $(\mathrm{OM})$ e à orientação empreendedora (OE). O CE é o que permite ao indivíduo estar alerta para a internacionalização, ou seja, é o capital humano e social que permite ao empresário visualizar o futuro, reconhecer oportunidades, perseguir e reduzir riscos, e outros recursos únicos que, combinados, permitem a exploração de determinada oportunidade. OM está relacionada a uma cultura organizacional que busca estimular determinados comportamentos para geração de valor para os clientes de forma mais efetiva que os competidores. Muitas empresas concentram-se em necessidade latentes e mercados não atendidos, buscando descobrir, compreender e satisfazer as necessidades dos clientes. OE está relacionada à combinação de comportamentos inovadores, proativos, e à disposição para assumir riscos do empreendedor.

O modelo associa OE e OM como determinantes para inovação organizacional técnica e administrativa. Coloca a inovação como forma de as empresas conseguirem vantagens competitivas sustentáveis, já que OE e OM não são suficientes para criar vantagens competitivas sustentáveis. De fato, para conseguir a sustentabilidade a empresa necessita utilizar mecanismos de isolamento para se distanciar de seus competidores, e uma das formas de se isolar é por meio de inovações. Assim, no modelo, a inovação é colocada como mediadora da competitividade internacional de BGs. 
Foram também considerados dois fatores moderadores que determinam o impacto do desempenho de BGs. O primeiro, estrutura organizacional, está negativamente relacionado a OE, pois, quanto maior o nível de organização da empresa (formalização, centralização e departamentalização) menor será a autonomia e liberdade do empreendedor, inibindo dessa forma a criatividade dos empreendedores e a escolha de ideias ainda não testadas . O segundo fator, orientação de aprendizagem (OA), é considerado fundamental para BGs, pois permite o desenvolvimento de capacidades que são de grande importância para a internacionalização. Além disso, OA desempenha um papel fundamental na renovação de empresas, funciona como um intermediário entre a empresa e o ambiente, reduzindo o impacto de sobressaltos de ambiente, e serve para manter contatos estreitos com clientes, fornecedores, e outras partes interessadas, e assim aumenta a capacidade de a empresa lidar com mudanças ambientais inesperadas.

Freeman, Edwards e Schroder(2006) investigam as estratégias de pequenas BGs que possuem apenas clientes corporativos (business-tobusiness) e que atingem rápido crescimento internacional por meio de alianças e joint ventures com fornecedores e distribuidores. O primeiro objetivo do trabalho é identificar como a alta gerência de BGs utiliza sua rede de relacionamentos para desenvolver parcerias e alianças em modos de entrada múltiplos, com vistas a superar as limitações da empresa e levar inovações e tecnologias para o mercado internacional. O segundo objetivo é o de identificar como as relações das BGs se adaptam às mudanças das necessidades de seus parceiros no tempo. Os autores identificaram na literatura três grandes limitações que pequenas BGs enfrentam em seu processo de internacionalização: ausência de economias de escala, falta de recursos financeiros e de conhecimento, e aversão a risco.

No trabalho foi desenvolvido um framework conceitual que mostra cinco estratégias utilizadas para superar as três principais limitações de BGs. Como a alta gerência dessas empresas utiliza sua network para conseguir internacionalizar a empresa, o uso de inovações para conseguir vantagens competitivas e o gerenciamento de redes de relacionamento são os elementos chave de tais estratégias. No framework também são analisadas variáveis de ambiente internas e externas, e como essas variáveis impactam as limitações de BGs (Figura 5). 


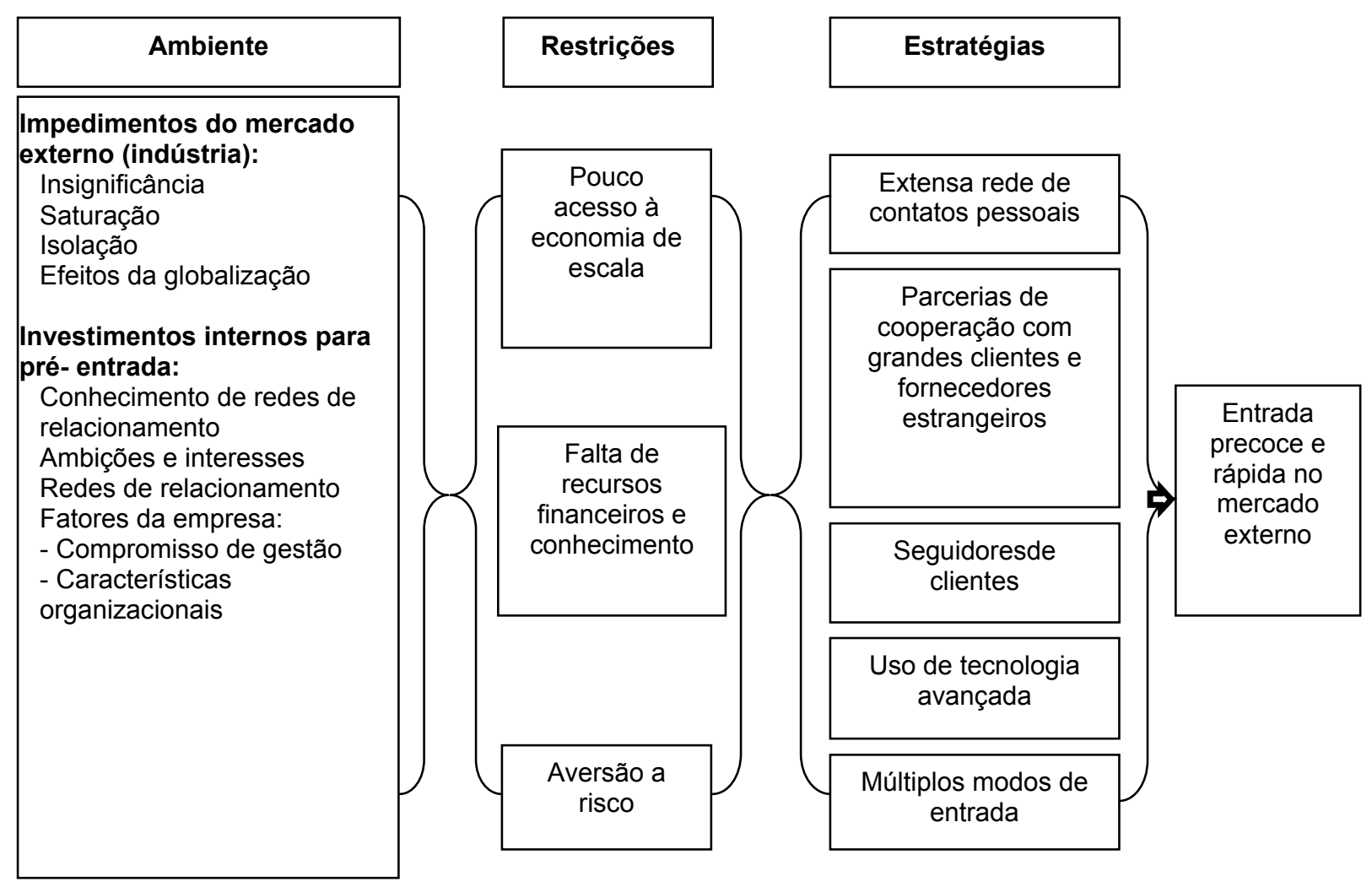

Figura 5 - Modelo conceitual das estratégias chave de internacionalização utilizadas por pequenas BGs.

Fonte: Freeman, Edwards e Schroder (2006, p. 48) 
As estratégias utilizadas foram: redes de contatos pessoais, forte relacionamento com grandes clientes e fornecedores estrangeiros, seguir os clientes, uso de tecnologia avançada e múltiplos modos de entrada. Também são mostrados como as mudanças nas redes de relacionamentos, por meio de novas relações formadas e redes pessoais adicionadas, são essenciais para o gerenciamento de empresas com rápido processo de internacionalização.

As variáveis de ambiente encontradas no estudo foram divididas em externas (indústria) e internas (empresa). Seriam elas que conduziriam a empresa a buscar sua internacionalização e a utilização simultânea de várias das estratégias mencionadas. As variáveis ambientais externas são: restrições no mercado, como o tamanho insignificante do mercado doméstico; saturação; isolamento; e efeitos da globalização. Já as variáveis internas são: conhecimento de redes de relacionamento; ambições e interesses; relações conectadas; redes de relacionamento; e fatores da empresa como compromisso gerencial e características organizacionais. No estudo também foi verificado que as variáveis internas exercem impacto maior no desempenho da empresa do que as variáveis externas.

Redes de contatos pessoais - Os gerentes seniores de BGs utilizam suas redes de contatos para se conectarem rapidamente a mercados internacionais por meio de grandes clientes e fornecedores estrangeiros. Gerentes de BGs apresentam forte comprometimento na participação de mercados internacionais, direcionamento e disposição para assumir riscos. Tais características servem de suporte para o reconhecimento das limitações das BGs e as possíveis estratégias para contorná-las.

Forte relacionamento com grandes clientes e fornecedores estrangeiros O gerenciamento da expansão internacional acelerada de uma BG coloca pressão significativa sobre os recursos da empresa, de modo que a criação da confiança com parceiros internacionais deve ser estabelecida rapidamente, o que também cria riscos para a BG. Porém, assumir riscos pode ser compensado pela geração de referências de parceiros já estabelecidos em redes de relacionamento que, de certo modo, protegem a BG de parceiros desconhecidos. Desse modo, a gerência poderá criar mais parceiros em sua rede de relacionamentos e, consequentemente, expandir a empresa internacionalmente. Por meio da criação de relacionamentos fortes e adaptáveis com grandes fornecedores internacionais e do alcance de elevados padrões de 
qualidade, os gestores podem minimizar riscos como o de troca ou cancelamento de grandes encomendas.

Seguir os clientes - Existem grandes riscos associados a decisões de expansão e penetração em mercados internacionais, principalmente para pequenas empresas que não dispõem de muitos recursos. Dessa forma, a estratégia de seguir grandes clientes em mercados internacionais pode ser uma boa opção para pequenas BGs. Ao seguir um cliente, uma BG irá ganhar mais referências no mercado externo e consequentemente mais relacionamentos de negócio e mais oportunidades de expansão.

Uso de tecnologia avançada- Empresas com base em conhecimento intensivo têm proliferado na nova economia global e são vistas como mais proativas em suas estratégias de internacionalização do que empresas tradicionais. No estudo não foi encontrado nenhuma BG que não fosse de alta tecnologia em sua respectiva indústria, ou que não fosse líder de mercado em processos de alta tecnologia, sendo os processos de alta tecnologia utilizados para apoiar a empresa em seu processo de internacionalização acelerado.

Múltiplos modos de entrada - Pequenas empresas tendem a utilizar múltiplas estratégias para entrar rapidamente em mercados internacionais, que utilizam diversos modos de entrada, tais como: alianças estratégicas, joint ventures, subsidiárias, seguimento de clientes, parcerias colaborativas etc. 


\section{3 \\ Metodologia de pesquisa}

Neste capítulo é apresentada a metodologia adotada, incluindo a apresentação do problema, as perguntas que orientam a pesquisa, o método utilizado, as vantagens e desvantagens do método, os métodos de coleta e análise dos dados e as limitações do estudo.

\section{1.}

\section{Problema e perguntas da pesquisa}

O objetivo deste estudo é investigar o processo de internacionalização precoce de duas empresas brasileiras de jogos eletrônicos - Manifesto Games e Aquiris Games - utilizando o método de estudo de casos, com o propósito de identificar os motivos para essas empresas buscarem o mercado exterior de forma acelerada e como elas conseguem se tornar sustentáveis em um mercado internacional tão competitivo. Para orientar a pesquisa a respeito dos processos de internacionalização e as estratégias adotadas foram criadas as seguintes questões:

$>$ Quais foram os principais determinantes do processo de internacionalização?

Quais foram os critérios adotados nas escolhas dos países?

Que fatores podem ser apontados pela empresa como facilitadores dos processos de internacionalização?

$>$ Que fatores podem ser considerados barreiras ou obstáculos ao longo do processo de internacionalização?

$>$ Quais foram as estratégias adotadas pelas empresas para se manterem sustentáveis no mercado internacional?

Quais foram os critérios para criação das parcerias e alianças? 


\section{2. \\ Método de pesquisa}

Devido à complexidade do fenômeno estudado, que busca identificar estratégias, motivações e barreiras ao processo de internacionalização das empresas analisadas, optou-se pelo método de estudo de caso.

O método de estudo de casos é utilizado quando se busca analisar questões com maior complexidade, ou desconhecidas. Normalmente é utilizado para identificar questões do tipo "como" e o "por que" de um fenômeno, as quais o pesquisador possui pouco controle ou nenhum (YIN, 2003). Um dos benefícios em utilizar o método de estudo de casos é a possibilidade de analisar vasta variedade de dados provenientes de diversas fontes. Dessa forma, foi possível buscar informações relevantes para o estudo em entrevistas com os dirigentes das empresas e relacioná-las com dados secundários obtidos na internet a respeito das empresas e a indústria de jogos eletrônicos. Yin (2003) descreve o método de estudo de caso como um método que busca investigar fenômenos contemporâneos em um contexto de vida real; quando os limites entre fenômeno e contexto não são claros e no qual múltiplas fontes de evidência são utilizadas.

O estudo de caso permite a realização de estudos em profundidade referentes a um ou poucos objetos que são exaustivamente analisados, buscando o conhecimento amplo e detalhado desses objetos (GIL, 2002). Para Gil (2002) o uso do método de estudo de caso nas ciências sociais é de grande importância, pois fazer a distinção entre o fenômeno estudado e o contexto em que está inserido é um dos grandes desafios para os pesquisadores, e o uso de procedimentos com alto nível de estruturação, como os experimentos e levantamentos, pode não ser adequado. Assim, o autor listou os principais propósitos na utilização do método de estudo de caso nas ciências sociais: explorar situações da vida real cujos limites não estão claramente definidos; preservar o caráter unitário do objeto estudado; descrever a situação do contexto em que está sendo feita determinada investigação; formular hipóteses ou desenvolver teorias; e explicar as variáveis causais de determinado fenômeno em situações muito complexas que não possibilitam a utilização de levantamentos e experimentos. 


\section{3.}

\section{Escolha dos casos}

Para este trabalho foram investigadas na literatura as características necessárias para uma empresa ser considerada Born global. Com auxilio de gestores da Agência Brasileira de Promoção de Exportações e Investimentos (Apex Brasil) foram identificadas duas empresas que se destacaram dentro do setor de jogos eletrônicos e que possuem as características necessárias em seus processos de internacionalização para serem consideradas Born Globals. No

Quadro 3 são mostradas como as empresas estão alinhadas com as características básicas de uma Born Global adotadas neste trabalho.

Quadro 3 - Características das Born Globals Aquiris Games e Manifesto Games

\begin{tabular}{|c|c|c|}
\hline Características & Aquiris Games & Manifesto Games \\
\hline Data de fundação & $\begin{array}{l}\text { Fundada em 2006, e } \\
\text { inicio das atividades em } \\
2007 \text {. }\end{array}$ & 2005 \\
\hline $\begin{array}{l}\text { Data da } 1^{a} \text { atividade } \\
\text { internacional } \\
\text { (critério de corte de } 3 \\
\text { anos) }\end{array}$ & $\begin{array}{l}2010,3 \text { anos após o } \\
\text { inicio } \\
\text { das }\end{array} \begin{array}{r}\text { suas } \\
\text { atividades. }\end{array}$ & $\begin{array}{l}2005, \text { no ano da } \\
\text { fundação. }\end{array}$ \\
\hline $\begin{array}{l}\text { Relevância das } \\
\text { atividades } \\
\text { internacionais para a } \\
\text { empresa (critério de } \\
\text { corte de } 30 \% \text { do } \\
\text { faturamento a contar do } \\
\text { início das atividades } \\
\text { internacionais) }\end{array}$ & $\begin{array}{l}90 \% \text { do faturamento } \\
\text { proveniente } \\
\text { exportação de serviços } \\
\text { em 2012, sendo } 80 \% \\
\text { para os EUA. }\end{array}$ & 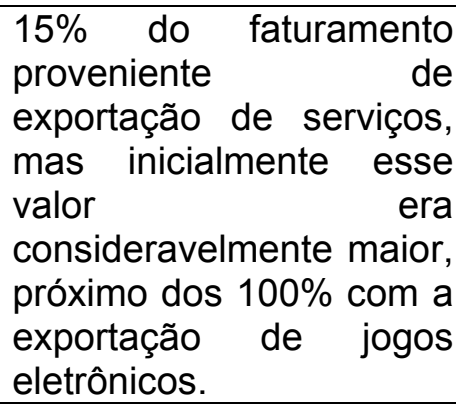 \\
\hline $\begin{array}{l}\text { Abrangência geográfica } \\
\text { (critério de corte: deve } \\
\text { buscar atuar em } \\
\text { diversas regiões do } \\
\text { planeta, mesmo que de } \\
\text { forma indireta) }\end{array}$ & $\begin{array}{l}\text { Busca criar negócios nos } \\
\text { EUA, mas com } \\
\text { empresas de várias } \\
\text { regiões, como: Japão, } \\
\text { Vietnã, Dinamarca. }\end{array}$ & $\begin{array}{l}\text { Busca atuação global, } \\
\text { mas com foco nos EUA } \\
\text { para venda de jogos } \\
\text { eletrônicos. Para a } \\
\text { atuação em outsourcing, } \\
\text { o foco da empresa está } \\
\text { na América do Norte, } \\
\text { com maior concentração } \\
\text { nos EUA. }\end{array}$ \\
\hline $\begin{array}{l}\text { Escopo das atividades } \\
\text { internacionais }\end{array}$ & $\begin{array}{l}\text { Produção de jogos } \\
\text { eletrônicos, coproduções } \\
\text { de jogos com parceiros } \\
\text { internacionais, }\end{array}$ & $\begin{array}{l}\text { Produção de jogos } \\
\text { eletrônicos, prestação de } \\
\text { serviços de out sourcing } \\
\text { jogos } \\
\text { prospecção de cletrônicos, } \\
\text { para serviços dentes } \\
\text { outsourcing em feiras } \\
\text { internacionais. }\end{array}$ \\
\hline
\end{tabular}




\section{4. Método de coleta de dados}

Yin (2003) recomenda que sejam utilizadas diferentes fontes de dados. Dessa forma, este estudo combina a utilização de dados primários e secundários. Para os dados primários foram utilizadas entrevistas com diretores responsáveis pelas áreas de internacionalização das empresas Aquiris Games e Manifesto Games. Para os dados secundários foi utilizada vasta documentação encontrada na internet referente às empresas e à indústria de jogos eletrônicos. Dentre os dados secundários encontrados estão: documentos das empresas, como apresentações, publicações em mídias online, informações nos websites das empresas, informações setoriais em diversos websites especializados em jogos eletrônicos, análises de especialistas da indústria de jogos eletrônicos, relatórios desenvolvidos por associações de desenvolvedores de jogos eletrônicos no Brasil e estudos acadêmicos sobre o setor.

Em um primeiro momento, foram identificadas, junto a gestores da APEX, as empresas com maior destaque no setor de jogos eletrônicos, e que já se encontrassem em um processo de internacionalização mais avançado.

Por meio dos dados secundários foi possível traçar um histórico preliminar das empresas e sua atuação, além de também desenvolver uma breve análise do setor de jogos eletrônicos no Brasil. Posteriormente, por intermédio de gestores da Apex Brasil, foram identificadas as pessoas chave a serem entrevistadas, para exemplificar os processos de internacionalização. Para a Aquiris Games, o contato estabelecido foi com o diretor comercial, Sandro Manfredine, e para a Manifesto Games, o contato estabelecido foi com o diretor de negócios, Vicente Vieira Filho. Com base nas informações coletadas e no referencial teórico criado, foi desenvolvido um roteiro para entrevistas semiestruturadas, que serviram de fonte de dados primários para este trabalho.

Posteriormente, em julho de 2013, foram realizadas duas entrevistas, uma para cada empresa através do Skype (software de comunicação via internet). As entrevistas tiveram uma duração aproximada de uma hora e quarenta minutos cada. As duas entrevistas foram gravadas e transcritas. Na fase de compilação das entrevistas e triangulação com os dados secundários, surgiram algumas questões que foram posteriormente respondidas pelos entrevistados via e-mail. 


\section{5. \\ Método de análise de dados}

Inicialmente foram analisados os dados secundários sobre as empresas escolhidas e sobre a indústria brasileira de jogos eletrônicos para identificar as principais atividades das empresas e para compreender o contexto em que essas empresas estão inseridas.

Posteriormente, foram desenvolvidos os casos utilizando como base os dados secundários e as entrevistas realizadas.As informações coletadas foram analisadas de acordo com as perguntas de pesquisa desenvolvidas a partir da revisão de literatura,que formam as questões formuladas no presente estudo. Assim, a análise e a interpretação dos resultados empíricos dos estudos de caso foram confrontadas com as teorias e modelos apresentados sobre a internacionalização de empresas.

\section{6. Limitações do estudo}

Apesar da crescente utilização do método de estudo de caso na área de Administração (e nas Ciências Sociais), ainda existe resistência a sua utilização. Para Gil (2002), tal resistência está associada a algumas críticas ao método, tais como: falta de rigor metodológico, pois ele não obedece a procedimentos metodológicos rígidos, como os que existem em experimentos e levantamentos. Assim, permitiria mais facilmente a ocorrência de vieses, que poderiam comprometer a qualidade dos resultados. No entanto, os vieses não existem apenas nesse método, eles também podem ser encontrados em qualquer metodologia de pesquisa. Assim, para o pesquisador diminuir os efeitos de potenciais vieses em estudos de caso, é necessário que ele redobre sua atenção tanto no planejamento quanto na coleta e análise dos dados, o que também pode ser reduzido com o uso de técnicas como gravação e transcrição das entrevistas e triangulação das fontes de dados. Esses procedimentos foram adotados no presente estudo.

Outra crítica ao método refere-se à impossibilidade de generalização dos resultados obtidos nos casos para a população. Porém, o principal propósito dos estudos de caso é o de gerar uma visão abrangente do problema, identificar fatores que influenciam o problema ou que são influenciados por ele, ou seja, o método não deve ser utilizado para gerar conhecimentos a respeito de uma população (GIL, 2002). 
Outra crítica é referente ao longo tempo demandado para a realização de pesquisas, que, por isso, muitas vezes acabam ficando pouco consistentes. Porém esse método vem evoluindo ao longo das décadas, e já é possível comprovar que é factível desenvolver estudos de caso em períodos mais curtos e com resultados passíveis de confirmação por outros estudos (GIL, 2002).

Neste estudo alguns aspectos poderiam também apresentar algumas limitações, como o reduzido número de entrevistas, com apenas uma entrevista por empresa. Para minimizar esse problema foram utilizados dados secundários sobre as empresas pesquisadas e uma análise da indústria de jogos eletrônicos no Brasil e no mundo. Dessa forma, foi possível fazer uma triangulação das informações, além de analisar as empresas dentro do contexto em que estão inseridas e a evolução delas junto com a indústria de jogos eletrônicos nacional e internacional. 


\section{A indústria de jogos eletrônicos}

Neste capítulo é mostrada a evolução da indústria de jogos eletrônicos, descrevendo-se suas principais características no Brasil e no Mundo, buscando proporcionar um quadro geral do setor. Os seguintes tópicos são abordados: os tipos de jogos existentes e suas finalidades, as características das empresas desenvolvedoras de jogos eletrônicos e dos publishers, as principais associações da indústria brasileira de jogos eletrônicos, as políticas de fomento a indústria de jogos eletrônicos no Brasil e no Mundo, o mercado de trabalho na indústria brasileira de jogos eletrônicos, a formação de profissionais de jogos eletrônicos, e a internacionalização da indústria brasileira de jogos eletrônicos.

\section{1. \\ Evolução da indústria de jogos eletrônicos}

A história dos jogos eletrônicos (games) começa em 1962, quando um grupo de estudantes do Massachusetts Institute of Technology (MIT), desenvolve o primeiro jogo eletrônico, conhecido como Spacewar, que para jogá-lo era necessário um computador que ocupava uma mesa inteira.

Em 1971, a empresa americana Magnavox começa a desenvolver o primeiro console de jogos eletrônicos para ser conectado à TV. No mesmo ano, o engenheiro eletrônico Nolan Bushnell faz uma adaptação do jogo Spacewar, criando um computador, chamado de Computer Space, que tinha como única função jogar o Spacewar. O Computer Space ficou conhecido como o primeiro arcade (ou fliperama no Brasil). Bushnell pouco tempo depois fundou a Atari, que se transformou em uma das maiores empresas de jogos eletrônicos da história. Em 1972, Bushnell, já na Atari, lança mais um fliperama, chamado Pong, que no ano seguinte passa a ganhar muito destaque, chamando a atenção de outras empresas que lançam também fliperamas similares. (UOL, [s.d.]) 
Então, na década de 70, surgiram os primeiros consoles de jogos eletrônicos, criados pelas empresas Atari e Magnavox, e os primeiros aparelhos de fliperama no mercado.O "Pong", da Atari, passou a ser conhecido como um dos primeiros jogos eletrônicos comerciais. Apesar de esses jogos terem surgido com o lançamento de aparelhos (hardware) no mercado, foram os jogos eletrônicos (software) os maiores responsáveis pelo crescimento da indústria de jogos eletrônicos (CARDOSO, 2013).

Atualmente, a indústria de jogos eletrônicos ainda possui característica oligopolista parecidas com existentes desde a sua criação em termos de hardware, com empresas como a Sony (PS3), Microsoft (XBox360) e Nintendo (Wii) dominando o mercado de consoles de jogos eletrônicos. Porém, apesar do oligopólio dessas empresas, diversos outros dispositivos surgiram no mercado, como os computadores pessoais (PC), aparelhos móveis, celulares, tablets, e consoles portáteis, que apesar de não terem como principal função o jogo, com exceção dos consoles portáteis, podem servir para tal objetivo e dessa forma transformaram o mercado de hardware de jogos eletrônicos em um mercado menos oligopolizado, visto que diversas empresas fabricam esses dispositivos, estando entre elas: Apple, Google, LG, Samsung, Nokia, Blackberry, Asus, Dell, entre outras (CARDOSO, 2013).

No Quadro 4 é possível verificar as principais empresas com seus principais consoles na história dos consoles de jogos eletrônicos.

Quadro 4 - Desenvolvedoras de Consoles e seus jogos eletrônicos.

\begin{tabular}{|l|l|l|}
\hline \multirow{4}{*}{1970} & \multicolumn{1}{|c|}{ Empresas } & \multicolumn{1}{c|}{ Produtos } \\
\cline { 2 - 3 } & Atari (EUA) & Pong e Atari 2600 \\
\cline { 2 - 3 } & Magnavox (EUA) & Odyssey e MagnavoxOdyssey 2 \\
\cline { 2 - 3 } & Coleco (EUA) & ColecoTelstar \\
\cline { 2 - 3 } & FairchildSemiconductor & FairchildChannel F \\
\cline { 2 - 3 } & Philco/Ford (BR) & Telejogo \\
\hline \multirow{4}{*}{1980} & Atari (EUA) & Atari 5200, Atari 7800 \\
\cline { 2 - 3 } & Nintendo (JP) & NES \\
\cline { 2 - 3 } & SEGA (JP) & SG-1000, Master System e Genesis \\
\cline { 2 - 3 } & Mattel (EUA) & Intellivision e Intellivision II \\
\cline { 2 - 3 } & Coleco & Colecovision \\
\cline { 2 - 3 } & NEC (JP) & TurboGrafx 16 \\
\cline { 2 - 3 } & SNK & NeoGeo \\
\cline { 2 - 3 } & World of Wonders (EUA) & Action Max \\
\cline { 2 - 3 } & Gradiente (BR) & Phantom System (clone NES) \\
\hline
\end{tabular}




\begin{tabular}{|c|c|c|}
\hline & Empresas & Produtos \\
\hline \multirow[t]{6}{*}{1990} & Nintendo & Super NES e Nintendo 64 \\
\hline & Sony & Playstation \\
\hline & SEGA & Sega Saturn e Sega Dreamcast \\
\hline & Atari & Jaguar \\
\hline & SNK & NeoGeo CD \\
\hline & 3DO Company & $3 \mathrm{DO}$ \\
\hline \multirow{3}{*}{$\begin{array}{l}2000 \\
- \\
2004\end{array}$} & Sony (JP) & PS2 \\
\hline & Microsoft (EUA) & $\mathrm{XBOX}$ \\
\hline & Nintendo (JP) & Gamecube \\
\hline \multirow{4}{*}{$\begin{array}{l}2005 \\
- \\
2012\end{array}$} & Sony (JP) & PS3 \\
\hline & Microsoft (EUA) & XBOX 360 \\
\hline & Nintendo (JP) & Wii \\
\hline & Tectoy (BR) & Zeebo \\
\hline \multirow[t]{7}{*}{2013} & Ouya, Inc. & Ouya \\
\hline & Nvidia (EUA) & Nvidia Shield \\
\hline & Nintendo (JP) & Nintendo 2DS \\
\hline & PlayJam & GameStick \\
\hline & Sony (JP) & PlayStation 4 \\
\hline & Microsoft (EUA) & Xbox One \\
\hline & MadCatz (EUA) & MOJO \\
\hline
\end{tabular}

Fonte: Cardoso $(2013$, p. 39)

Apesar do pequeno número de empresas produtoras de hardware, a produção de jogos (software) sempre teve a participação de uma gama abrangente de profissionais e empresas. Na Figura 6 é possível verificar como era a estrutura de negócio da indústria nas décadas de 1970 e 1980 (CARDOSO, 2013). Na figura não foram representados os varejistas, pois esses variam de país para país. 


\begin{tabular}{|c|c|c|}
\hline \multicolumn{3}{|l|}{ CRIAÇÃO } \\
\hline \multicolumn{2}{|c|}{$\begin{array}{l}\text { Proprietaries de consoles: Atari, Sega, } \\
\text { Nintendo, Coleco, Magnavox, MattelElectronics, etc }\end{array}$} & \multirow[b]{3}{*}{ Varejistas } \\
\hline $\begin{array}{l}\text { GrandesPublishers: Elect } \\
\text { Capcom, Konami, Square, Univ }\end{array}$ & $\begin{array}{l}\text { ic Arts, Activision, } \\
\text { al Games, } 20^{\text {th }}\end{array}$ & \\
\hline $\begin{array}{l}\quad \text { Pequenos/Médios/Grand } \\
\text { esEstúdios: Midway, Orca } \\
\text { Corporation, Mylstar } \\
\text { Electronics Inc, Western } \\
\text { Technologies Inc, Taito } \\
\text { Corporation, Tecmo, Nexa } \\
\text { Corporation, Sanritsu, Data } \\
\text { East, Codemasters, Technos } \\
\text { Japan, Seibu Kaihatsu. }\end{array}$ & $\begin{array}{l}\quad \text { Publishers: } \\
\text { Atari, Sega, } \\
\text { Phillips, Salio, M- } \\
\text { Network, } \\
\text { Sculptured } \\
\text { Software, Panda } \\
\text { Computer } \\
\text { Games, } \\
\text { Activision, etc }\end{array}$ & \\
\hline
\end{tabular}

Figura 6 - Estrutura de negócio da indústria de jogos eletrônicos nas décadas de 1970 e 1980. Fonte: Cardoso (2013, p. 45)

A partir da década de 1990, com o surgimento dos MMOGs (Massive Multiplayer Online Games), que são jogos capazes de suportar uma enorme quantidade de jogadores ao mesmo tempo compartilhando cenários e com a possibilidade de interação entre si, as empresas desenvolvedoras de jogos passam também a utilizar a internet para distribuir seus produtos. Assim, devido à possibilidade de interagir diretamente com os usuários dos jogos, essas empresas passam a não depender tanto de distribuidoras para comercializar seus jogos. (CARDOSO, 2013)

A Erro! Fonte de referência não encontrada. mostra a indústria de jogos eletrônicos atualmente. Nela é possível verificar algumas mudanças significativas, como a transferência do varejo de jogos eletrônicos para redes sociais, lojas virtuais de aplicativos e sites de jogos online. É possível verificar também um aumento das opções de plataformas de jogos: enquanto antes só era possível jogar por meio de consoles e computadores pessoais, agora é 
possível jogar também por meio de redes sociais, celulares, tablets e outros (CARDOSO, 2013).

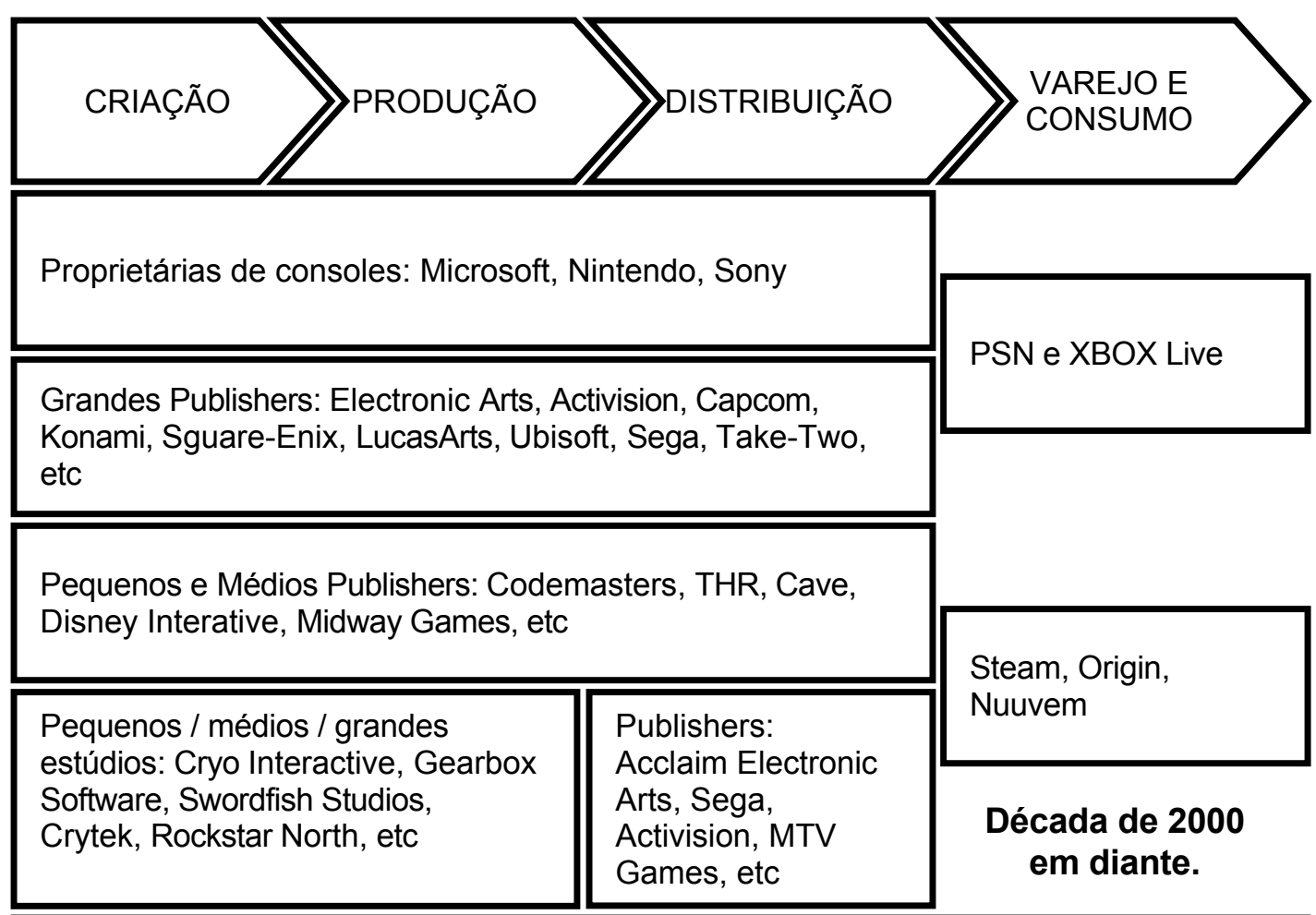

Estúdios / Publishers de MMO: Blizzard, NCSoft, Sony Online Entertainment (SOE), HiTech Creations, Hive.

Estúdios / Publishers Mobiles: Gree, Chillingo, 6waves, Rovio ,Gameloft, Capcorn, Tapulous, EA Mobile, Backflip Studios, etc

Apple Store, Android Market, produtoras de celulares

Estúdios / Publishers Mobiles: Vidia, Mojang, Flexion, Indiagames, Hyperkani, Playbuff, etc

Publishers Mobile: Gree, Chilingo, 6waves, EAMobile
Apple Store, Android Market, produtoras de celulares

Facebook, Orkut, Kongregate, etc

Estúdios / Publishers jogos Sociais e Web: Kixeye, Zynga, ElectronicArts, Ubisoft, Stomp Games, Fuzz Rabbit, Pop Pace, etc

Figura 7 - Estrutura de negócio da indústria de jogos eletrônicos atualmente Fonte: Cardoso (2013, p. 47)

$\mathrm{Na}$ década de 2000 começam a surgir ferramentas para venda direta de jogos para computadores pessoais, tais como: Steam, Origin, Uplay, que possibilitam aos usuários comprar, "baixar" e ativar o jogo pela internet. Essa nova opção não apenas facilitou a compra de jogos para os usuários, mas também possibilitou que as empresas desenvolvedoras de jogos tivessem um controle muito forte das vendas dos seus jogos e, consequentemente, dificultou 
a pirataria desses jogos eletrônicos. Posteriormente, essas ferramentas também foram desenvolvidas para consoles, como PSN, XBOX Live e Wii Shop Channel, o que levou as produtoras dos consoles a disponibilizar ferramentas para criação de jogos, para que pequenas empresas pudessem desenvolver seus jogos eletrônicos para os consoles (CARDOSO, 2013).

Essa nova estratégia das principais desenvolvedoras de consoles (Sony, Microsoft e Nintendo) viabilizou a participação de pequenas empresas no mercado de jogos para consoles, que antes só tinha espaço para grandes desenvolvedoras. Dessa forma, os pequenos produtores de jogos para console podem coexistir com as grandes desenvolvedoras, pois buscam desenvolver jogos mais simples e com custo menor, porém utilizando a criatividade como diferencial (CARDOSO, 2013).

"Isto se dá por causa da menor ocorrência de economias de escala dentro deste segmento. Produtoras menores podem desenvolver produtos criativos com menos recursos e obter grandes fatias de mercado, como foi o caso da Rovio com o lançamento de AngryBirds." (CARDOSO, 2013)

\section{2. \\ Segmentação dos jogos eletrônicos}

Neste estudo os jogos eletrônicos foram segmentados primeiramente de acordo com o seu propósito, podendo ser de jogos de entretenimento, jogos sérios (serious games), ou propagandas in-game. Na segmentação por entretenimento, os jogos foram categorizados por plataformas. Para Querette et al. (2012) a indústria de jogos eletrônicos de entretenimento está segmentada da seguinte forma: Consoles (Playstation, Xbox, Wii), PC Offline; Dispositivos Móveis (celulares, tablets, consoles portáteis), Jogos Online Multiusuários Massivos (MMO), e os jogos casuais. A empresa de consultoria Newzoo também criou uma divisão feita por plataformas,porém incluiu mais uma categoria, aSocial Games, que considera os jogos desenvolvidos para redes sociais.

Para Querette et al. (2012), cada segmento possui uma cultura de produção diferente e com distintos meios de acesso ao mercado. Por exemplo, as empresas produtoras de jogos para consoles necessitam de kits de desenvolvimento proprietários específicos para cada console e com regras restritas de distribuição. Já as desenvolvedoras de jogos casuais apresentam ciclos de desenvolvimento mais curtos e independentes, que envolvem menores custos e riscos de produção, porém lidam com maior dificuldade na comercialização dos seus jogos, pois têm que enfrentar mercados mais pulverizados e muito competitivos. 


\subsection{1.}

\section{Divisão dos jogos eletrônicos de entretenimento}

\subsubsection{1. \\ Social networks games}

São jogos em sites de redes sociais ou em smartphones que apresentam as seguintes características: são jogos multiplayer, que utilizam conexões sociais de um jogador, como parte do jogo; são jogos em que a jogabilidade principal envolve a socialização ou atividades sociais como conversar ou negociar; são jogos baseados em turnos, que são jogados dentro de um contexto social ou com os amigos; são jogos casuais competitivos que incluem as classificações dos jogadores no jogo, porém são consideradas apenas as pessoas que façam parte da lista de amigos do jogador (CHEN, 2009).

\subsubsection{2.}

\section{Casual games}

São jogos simples que podem ser jogados em diversos tipos de dispositivos. Eles podem ser jogados diretamente no navegador de internet ou "baixados" para um dispositivo, como smartphone, tablets, computadores etc. Diferente dos jogos tradicionais, eles são mais fáceis de serem jogados e normalmente servem como um passatempo. São jogos com gráficos mais simples e de baixa complexidade, o que facilita o seu desenvolvimento e reduz o tempo e o custo de produção. Os jogos casuais ganharam muita popularidade e possuem preços menores que os jogos convencionais.

\subsubsection{3.}

\section{Mobile games}

Mobile Games são desenvolvidos para dispositivos portáteis, como celulares, tablets e outros. São jogos eletrônicos que podem variar em sua sofisticação e atualmente contam com diversos recursos, como Bluetooth, Wi-Fi e 3G, 4G, e outros. Assim, com a utilização desses recursos, esses jogos podem trazer novas experiências para seus jogadores como permitir jogos multiplayer que utilizem a localização geográfica dos jogadores via GPS dos aparelhos de celular. 


\subsubsection{4.}

\section{Massive multiplayer online games}

São jogos que permitem que milhares de pessoas ao redor do mundo interajam entre si por meio da internet, para isso os MMOG disponibilizam cenários virtuais que são compartilhados pelos jogadores. Devido a popularização dos jogos eletrônicos $\mathrm{MMO}$, as empresas que antes produziam apenas jogos single player passaram a investir na produção de jogos multiplayer.

Nesses jogos foram criados ainda diferentes modelos de negócios, tais como: P2P ("Pay to Play"), em que são cobradas mensalidades para poder jogar; B2P ("Buy to Play"), em que é necessário comprar o jogo, mas dispensam-se mensalidades para continuar jogando; F2P ("Free to Play") oferece acesso gratuito, porém normalmente realiza vendas de itens/vip como forma de obter retorno financeiro. (MORRIS, 2013).

\subsubsection{5.}

\section{Console Games}

São jogos destinados para os consoles de jogos eletrônicos. Geralmente apresentam grande sofisticação gráfica, e costumam ser jogos eletrônicos mais complexos, que normalmente exigem dos jogares o desenvolvimento de habilidades que só são adquiridas após algum tempo de treinamento. Esses jogos podem ser adquiridos de duas formas, por meio da compra física no varejo, onde são encontrados normalmente em mídias ópticas (CD, DVD ou BluRay), ou podem ser adquiridos pela internet, em que os jogos "baixados" são armazenados diretamente nos consoles de jogos eletrônicos.

\subsubsection{6.}

\section{PC / Macboxed / downloaded games}

São jogos desenvolvidos para computadores que, geralmente, utilizam sistemas operacionais Windows ou Mac. Esses jogos atualmente podem ser adquiridos fisicamente no varejo ou por meio de downloads na internet. Eles evoluíram de jogos extremamente simples, parecidos com os jogos casuais, para jogos de alta complexidade de jogabilidade e gráfica, podendo ser comparados aos jogos mais sofisticados para consoles de última geração. Devido à facilidade de desenvolvimento de jogos para computador, que não necessitam de kits de desenvolvimento proprietários como os jogos para consoles, e o menor custo de produção, esses jogos ganharam muita 
popularidade entre as empresas desenvolvedoras, que criaram uma vasta gama de jogos para o mercado.

Outro fator, que ajudou na popularização dos jogos para computador, é a possibilidade de os usuários melhorarem seus computadores gradualmente, permitindo que jogos eletrônicos novos, com gráficos mais avançados, possam ser jogados em computadores mais antigos, apenas com a atualização de algumas peças, ou seja, sem a necessidade de comprar um dispositivo novo, como é o caso dos consoles de jogos eletrônicos.

\subsection{2.}

\section{Serious games}

O site da Serious Game University aborda os mais variados tipos de Serious games, descrevendo suas aplicações e classificações. Os Serious games são diferentes dos outros jogos, pois não têm como principal objetivo o entretenimento. Eles são criados com o objetivo de resolver problemas no mundo real.

Os serious games podem ser usados para diversos fins, tais como: educação, treinamento, simulação, formação de equipe, colaboração, redes sociais, publicidade, investigação, modelagem de negócios.

Eles também são usados em várias indústrias e setores, tais como: Defesa, Educação, Negócios, Exploração Científica, Saúde, Gerenciamento de Emergências, Planejamento Urbano, Engenharia, Religião, Política, Turismo, Patrimônio Cultural, e Conferência Virtual.

A Serious Game University classifica os serious games de acordo com seu propósito em:

\subsubsection{1.}

\section{Advergames}

São jogos criados para anunciar e promover um produto, organização ou ponto de vista.

\subsubsection{2.}

\section{Edutainment}

São jogos de entretenimento projetados para educação. Uma indústria que utiliza produtos edutainment é a de softwares infantis. Existem jogos, por exemplo, que buscam ensinar matemática, história e outras matérias para crianças, enquanto as mantêm entretidas. 


\subsubsection{3.}

\section{Game-based learning}

São jogos que tentam balancear determinado conteúdo com a jogabilidade, e também levam em conta a habilidade do jogador em reter e aplicar os assuntos abordados nos jogos com a vida real, ou seja, buscam ensinar algum conteúdo que possa ser aplicado no mundo real por meio dojogo.

\subsubsection{4.}

\section{Newsgame}

São jogos que transmitem notícias ou conteúdo editorial interativo. Eles geralmente são criados em resposta a eventos atuais.

\subsubsection{5.}

\section{Training and simulation games}

São jogos criados para adquirir ou exercitar diversas habilidades, ou para ensinar comportamentos efetivos em determinados contextos, através da simulação de situações ou condições adversas.

\subsubsection{6. \\ Persuasive games}

São jogos criados com o objetivo de mudar atitudes e comportamentos dos jogadores por meio da persuasão.

\subsubsection{7. Organizational-dynamic}

Esses jogos têm como objetivo principal promover o desenvolvimento pessoal e a formação do caráter. Esses jogos ajudam na introdução de padrões de colaboração produtiva e na gestão de situações organizacionais mais complexas, como gestão de mudanças e difusão de inovações.

\subsubsection{8.}

\section{Games for health}

São jogos utilizados para terapia psicológica, treinamento cognitivo, reabilitação física e exergaming (ou seja, usados como forma de exercício).

\subsubsection{9.}

\section{Edumarket}

São jogos que combinam mais de um propósito entre os citados anteriormente (por exemplo: publicidade, persuasão e educação). 


\section{3.}

\section{Publishers e desenvolvedoras da indústria de jogos eletrônicos}

Nesta seção são analisados os dois principais tipos de empresas que compõem a indústria de jogos eletrônicos, os publishers e as desenvolvedoras de jogos eletrônicos.Posteriormente serão mostradas as principais diferenças entre elas.

\subsection{1.}

\section{Publishers}

Publishers de jogos eletrônicos funcionam de forma semelhante às redes de televisão e distribuidoras de filmes em DVD e Blu-ray. São os publishers os responsáveis pela produção e comercialização dos jogos eletrônicos. Além disso, também cabe a eles realizar estudos de mercado e a publicidade dos jogos. Os publishers geralmente são os financiadores dos jogos, que contratam os serviços de desenvolvedoras de jogos ou utilizam estúdios próprios. (OBSCURE, [s.d.])

Grandes publishers podem também acrescentar melhorias ao desenvolvimento do produto, já que eles costumam supervisionar o desenvolvimento dos jogos, auxiliando e sugerindo mudanças. No Quadro 5 é mostrado o ranking dos maiores publishers no mundo em 2012.

\begin{tabular}{|c|l|l|l|}
\hline Posição em 2012 & Publisher & País & Categoria \\
\hline 1 & ElectronicArts & EUA & Grandes \\
publishers
\end{tabular}

Quadro 5 - Ranking dos principais publishers no mundo em 2012 Fonte: Dietz(2013) 


\subsection{2.}

\section{Desenvolvedoras de jogos eletrônicos}

Elas podem produzir para uma grande variedade de dispositivos ou se especializar em apenas um. Existe atualmente uma grande quantidade de empresas de jogos eletrônicos, e muitas delas possuem apenas um ou dois funcionários, e produzem jogos mais simples e de baixo custo, porém existem também as grandes desenvolvedoras, que possuem centenas de funcionários e estão localizadas em diversos locais pelo mundo.

As desenvolvedoras de jogos eletrônicos são normalmente divididas em quatro principais tipos: First-Party, Second-Party, Third-Party e desenvolvedores independentes.

\subsubsection{1.}

\section{Desenvolvedoras First-Party}

As empresas First-Party, também conhecidas como desenvolvedoras inhouse, são empresas que fazem parte das empresas desenvolvedoras de consoles de jogos eletrônicos, e desenvolvem jogos que são exclusivos para suas detentoras.

\subsubsection{2. \\ Desenvolvedoras Second-Party}

São desenvolvedoras independentes que desenvolvem jogos com exclusividade para uma determinada plataforma, ou são subsidiárias de uma desenvolvedora de consoles de jogos eletrônicos e normalmente desenvolvem apenas jogos exclusivos para os consoles da empresa detentora.

\subsubsection{3.}

\section{Desenvolvedoras Third-Party}

São empresas contratadas por publishers para o desenvolvimento de algum jogo, que é geralmente criado para mais de um tipo de plataforma. Normalmente as duas empresas possuem participação na produção do jogo, mas, na maior parte das vezes, é o publisher que financia os projetos, e por isso geralmente consegue obter mais controle sobre o desenvolvimento do jogo que a desenvolvedora third-party. 


\subsubsection{4.}

\section{Desenvolvedores independentes}

São pequenas empresas que não são controladas por um publisher ou por uma desenvolvedora de consoles. Essas empresas normalmente produzem seus jogos utilizando recursos próprios e os distribuem através da internet por iniciativa própria ou por meio de associações com publishers.

\subsection{3.}

\section{Publishers e desenvolvedoras}

Pelizzari (2009) destacou algumas diferenças entre publishers e empresas desenvolvedoras de jogos eletrônicos.

\section{Publisher:}

D Distribui o jogo, ou seja, cuida de tudo o que é necessário para o jogo chegar aos potenciais consumidores, seja a distribuição física para o varejo ou a distribuição digital;

$>$ Financia o time de desenvolvimento do jogo;

> Escolhe quais títulos serão produzidos com base em estudos de marketing e público;

Define estratégias de marketing e publicidade.

> Deve ter um time de QA (Quality Assurance) para testar o jogo e garantir que as expectativas foram atingidas no produto que o publisher esperava receber da desenvolvedora.

\section{Desenvolvedora:}

Utiliza os financiamentos do publisher para produzir os jogos eletrônicos.

Mantém diálogo direto com o publisher, que exibe demonstrações de ideias criativas e protótipos para garantir que o jogo esteja de acordo com sua visão;

Deve manter o time motivado e atualizado. 


\section{4. \\ Características da indústria de jogos eletrônicos brasileira}

\subsection{1. Principais associações do setor brasileiro de jogos}

\subsubsection{1.}

\section{ABRAGAMES - Associação Brasileira dos Desenvolvedores de Jogos Digitais}

É uma entidade sem fins lucrativos criada em 2014 por empresas de desenvolvimento de jogos eletrônicos, e tem como principal objetivo fortalecer a indústria de jogos eletrônicos brasileira. A associação também busca levar a criatividade e tecnologia brasileiras no desenvolvimento de jogos para as principais empresas da indústria internacional.

\subsubsection{2.}

\section{BGD - Brazilian Game Developers}

Projeto criado em 2013 pela ABRAGAMES e a Agência Brasileira de Promoção de Exportações e Investimentos (APEX), que busca promover a exportação e internacionalização das desenvolvedoras de jogos eletrônicos brasileiras. Para isso, a BGD busca: o estabelecimento de metas e ferramentas para fortalecer o desenvolvimento de jogos eletrônicos no Brasil e para conquistar mercados internacionais; a capacitação das empresas brasileiras para trabalharem com os modelos de negócios internacionais; o apoio financeiro às empresas brasileiras de jogos eletrônicos para viabilizar a participação nos principais mercados internacionais; a prestação de serviços de assessoria de imprensa no Brasil e no exterior, consultorias especializadas, estudos de mercado etc.

\subsubsection{3.}

\section{SB GAMES - Simpósio Brasileiro de Jogos e Entretenimento Digital}

O SBGames, que inicialmente era chamado de Wjogos, foi criado em 2002 e tinha seu foco voltado apenas para a computação nos jogos eletrônicos. Posteriormente seu escopo foi aumentando e englobando as áreas de arte, design e outras questões relacionadas a indústria de jogos eletrônicos.

O SBGames é o simpósio da Comissão Especial de Jogos e Entretenimento Digital da Sociedade Brasileira de Computação (SBC), que é realizado anualmente para promover as áreas de jogos eletrônicos e entretenimento, e reúne anualmente pesquisadores, artistas, designers, professores e estudantes de universidades, centros de pesquisa e da indústria 
de jogos eletrônicos. A SB Games também conta com o apoio da Rede Brasileira de Tecnologia de Visualização (RBV).

\subsubsection{4.}

\section{ACI Games - Associação Comercial, Industrial e Cultural de Games}

A ACl GAMES é uma associação que tem como objetivos representar, regulamentar e incentivar a indústria e o comércio de jogos eletrônicos e incentivar a cultura dentro da indústria brasileira de jogos eletrônicos.

Para cumprir com seus objetivos, a ACl GAMES busca: o "Fomento à discussão sobre o papel dos jogos na sociedade, como meio de incentivo a cultura, auxílio à educação e sua função no desenvolvimento econômico do país; Estímulo ao acesso à tecnologia por pessoas ou grupos de pessoas; Estimular a melhoria técnica e profissional dos associados, no que diz respeito a produção, desenvolvimento, dublagem, distribuição, venda e outras atividades relacionado ao processo econômico de produção, distribuição e venda de jogos; Estimular o aperfeiçoamento e o cumprimento da legislação que instrumentalize a consecução dos presentes objetivos e estimular parcerias entre as empresas, governos e sociedade civil; Estimular o diálogo local e regional e solidariedade entre os diferentes segmentos sociais, participando junto a outras entidades de atividades civis que visem interesses comuns; Estimular e trabalhar em pesquisas acerca da utilização de jogos digitais; Fazer uso destas pesquisas para promover a utilização dos jogos em diversos ambientes da sociedade que promovam o entretenimento ou utilização de jogos de qualquer formato; Buscar maior identificação entre os usuários através da aproximação das linguagens entre os fabricantes, comerciantes e desenvolvedores; A defesa da liberdade de imprensa, liberdade de pensamento e liberdade de criação intelectual e artística, buscando auxiliar os órgãos da justiça e a sociedade civil a classificar e a identificar qual tipo de jogo é mais apropriado a cada faixa etária e respectivo público, permitindo que a sociedade decida que tipo de jogo deseja adquirir e consumir, repudiando a censura prévia de criação e a limitação criativa de seus associados e da sociedade civil." (ACIGAMES, 2013a)

\subsection{2.}

\section{A indústria nacional}

Com base no relatório da Acigames (2013b) são mostradas a seguir algumas características e necessidades importantes da indústria brasileira de jogos eletrônicos. 
Cerca de $70 \%$ das empresas de jogos eletrônicos no Brasil são formadas unicamente por seus sócios (com 1 ou 2 funcionários) e funcionam com grandes dificuldades. Muitas subsistem produzindo advergames e são poucas as que se sustentam criando jogos de fato, tanto para o mercado de varejo, quanto para as lojas digitais, como Apple Store, Steam etc. Menos de 10 empresas nacionais produzem jogos para consoles de mesa ou portáteis.

> No Brasil existem muitas desenvolvedoras que não são empresas constituídas, mas conseguem produzir bons jogos e geram alguma receita com venda digital. Estas empresas não se formalizam principalmente devido ao alto custo e burocracia existentes para se abrir e manter uma empresa no Brasil, além disso, os custos e burocracia para se fechar uma empresa caso o empreendimento dê errado é ainda maior.

$>\mathrm{O}$ custo de produção de um jogo nacional pode variar bastante. Um jogo independente pode custar de duzentos mil dólares, com um tempo de produção de cinco anos, até de quinze mil a trinta mil dólares com um tempo de produção de 4 a 6 meses, que é em média o necessário para criar um típico jogo de iPhone de sucesso. No Brasil, uma produção com um orçamento de duzentos mil dólares pode ser considerada como uma "superprodução". Na Apple Store empresas brasileiras lançam jogos que custaram menos de mil dólares, com um tempo de produção médio de cerca de 4 a 6 meses.

As empresas brasileiras apresentaram dificuldade no acesso a kits de desenvolvimento de jogos eletrônicos para consoles, porém esta realidade já está mudando (ROCHA, 2010).

\subsection{3.}

\section{Mercado de trabalho}

No relatório Acigames(2013b) foram também levantados algumas características do mercado de trabalho na indústria de jogos eletrônicos brasileira. 
Uma típica empresa nacional tem um custo inicial considerado alto. Um time de três pessoas (um programador, um artista e um game designer) pode ter um custo inicial de cinco mil dólares, apenas para compra de equipamentos e licenças de software para começar a trabalhar. Isso sem adicionar os custos de locação de imóveis, compra de mobiliário e manutenção de um escritório funcionando. As empresas constituídas também sofrem com os encargos trabalhistas, já que os funcionários são o principal "ativo" da empresa.

Os salários na indústria de jogos eletrônicos têm uma relação com os salários praticados pelo mercado de $\mathrm{TI}$, ou seja, é comum avaliar os profissionais que trabalham na arte de jogos como se fossem Web designers. Como existe pouca oferta de mão de obra (não só para jogos eletrônicos, mas também para TI em geral), o mercado está acostumado a praticar esses valores sem maiores questionamentos.

\subsection{4. Formação de profissionais específicos para a Indústria de jogos eletrônicos}

O relatório da Acigames (2013b)mostra alguns problemas e as relações entre o mercado de jogos eletrônicos, as instituições de ensino e os cursos com foco no desenvolvimento de jogos eletrônicos.

\subsubsection{1. 0 mercado}

Influencia diretamente a qualidade do que é produzido nas instituições de ensino que oferecem cursos de jogos.

A existência da pirataria afasta professores e alunos dos cursos de jogos.

> As leis trabalhistas e a carga tributária na produção de um jogo eletrônico são fatores impeditivos para o desenvolvimento de jogos de grande porte, pois tornam inviável manter uma equipe altamente qualificada (5 a 10 anos de experiência) e numerosa (50 a 200 pessoas, em média) que seja comprometida com o projeto do início ao fim (com carteira assinada e benefícios). 
Não existe uma "cultura gamer" plenamente instituída, o que torna o mercado de desenvolvimento de jogos eletrônicos uma "subcultura", e apenas as pessoas diretamente envolvidas na produção de jogos conhecem as dificuldades, o processo, os benefícios e as perspectivas desse mercado.

\subsubsection{2.}

\section{As instituições de ensino}

> São influenciadas diretamente pelo mercado e influenciam diretamente a qualidade dos cursos de jogos oferecidos no país atualmente.

$>$ Os cursos são criados sem fundamentação concreta e sem embasamento teórico significativo.

$>$ Faltam equipamentos, laboratórios e softwares necessários para a oferta de um curso de desenvolvimento de jogos adequado a uma produção de alto nível.

Apenas as instituições de ensino particulares conseguem oferecer equipamentos e estrutura física adequada aos cursos. Em boa parte das instituições de ensino públicas, os equipamentos e estrutura disponíveis estão muito distantes da realidade tecnológica atual necessária ao desenvolvimento de jogos eletrônico se, muitas vezes, fica ao encargo dos alunos e professores a aquisição de máquinas adequadas ao acompanhamento do curso.

$>$ É crescente o número de instituições de ensino oferecendo cursos de desenvolvimento de jogos atualmente, pois a demanda tem se ampliado significativamente nos últimos anos. Entretanto, não há nenhuma universidade, até o momento, capaz de atender os padrões internacionais da produção de jogos eletrônicos de grande porte.

\subsubsection{3.}

\section{Os cursos de desenvolvimento de jogos}

São influenciados diretamente pelas instituições de ensino e influenciam diretamente a contratação e o nível de conhecimento dos professores que lecionam nesses cursos.

Atualmente, os cursos de desenvolvimento de jogos oferecem matrizes curriculares heterogêneas, que, diferentemente do que acontece internacionalmente, tentam condensar conhecimentos multidisciplinares e áreas totalmente distintas em um programa de três ou quatro anos. 
A produção de jogos eletrônicos envolve, basicamente, três macro áreas: arte, programação e design (projeto)e é inviável abordar com consistência todas essas áreas e as competências relacionadas em um curso de graduação tradicional ou tecnológico.

$>$ Os cursos que oferecem matrizes curriculares multidisciplinares disponibilizam ao mercado profissionais com conhecimento superficial em diversas áreas, o que não atende as reais necessidades do mercado. Os poucos cursos que propõem matrizes específicas a uma das macro áreas disponibilizam ao mercado profissionais altamente especializados nas áreas específicas, mas que não conseguem criar um portfólio consistente em função do pouco conhecimento nas áreas em que não se especializaram.

Rocha (2010) analisa o cluster brasileiro de desenvolvimento de jogos eletrônicos situado na cidade de Pernambuco, no Nordeste brasileiro. No estudo foi verificado que existem bons profissionais em diversas áreas de tecnologia (tecnologia da informação, ciência da computação e outras), porém sem uma formação específica para o desenvolvimento de jogos eletrônicos. Assim, todos os profissionais que buscam trabalhar no cluster de Pernambuco passam por algum tipo de treinamento.

Para Rocha (2010), ainda não existem cursos universitários suficientes para atender a demanda e a maioria dos cursos existente não é específica para o desenvolvimento de jogos eletrônicos. Em Pernambuco apenas quatro instituições oferecem cursos específicos para a área. Foram criadas também disciplinas em cursos de graduação específicas sobre jogos eletrônicos, para tentar atender a demanda de profissionais.

Algumas empresas têm investido também na capacitação interna de seus empregados e também estão atuando junto às instituições de ensino para aumentar a oferta de cursos e disciplinas na área de jogos eletrônicos.

As instituições de ensino estão se voltando um pouco mais para os jogos eletrônicos, oferecendo disciplinas e cursos específicos. No cluster de Pernambuco já é possível verificar um aumento da mão de obra qualificada para produção de jogos eletrônicos, devido ao crescente interesse dos jovens pela produção de jogos, o aumento na quantidade dos cursos e disciplinas oferecidos nas instituições de ensino, as formações dentro das empresas, e a aproximação das empresas do cluster junto a essas instituições. Porém, apesar do recente 
crescimento da mão de obra especializada, a indústria brasileira ainda enfrenta muita dificuldade na retenção de talentos na área, pois esses talentos acabam sendo atraídos por outros países que possuem indústrias de jogos eletrônicos mais fortalecidas e desenvolvidas, e que oferecem melhores salários e condições de trabalho.

\subsection{5.}

\section{Políticas de fomento a indústria brasileira de jogos eletrônicos}

Atualmente já existem algumas medidas para fomentar a indústria nacional de jogos eletrônicos, como linhas de créditos não reembolsáveis, e a criação de projetos como o "Brazilian Game Developers Export Program", que foi desenvolvido para fomentar a exportação de jogos brasileiros.

As linhas de financiamentos públicos não reembolsáveis para ações de inovação tecnológica foram criadas no início de 2000 com o objetivo de incentivar a inovação nas empresas. Porém, tais linhas de financiamento são voltadas apenas para pesquisa, desenvolvimento e inovação. Dessa forma, atividades importantes, como ações de marketing e vendas, contratação de executivos, e compra ou aluguel de espaço físico não podem ser financiadas com essas verbas e por isso as empresas de jogos eletrônicos acabam tendo que buscar outras formas de financiamento(ROCHA, 2010).

O "Brazilian Game Developers Export Program" é um programa sem fins lucrativos, criado pela Associação Brasileira das Desenvolvedoras de Jogos Eletrônicos (ABRAGAMES) em parceria com a Agência Brasileira de Promoção de Exportações e Investimentos (Apex-Brasil), com o objetivo de fortalecer a indústria brasileira de jogos digitais, capacitando e criando novas oportunidades de negócios para as empresas brasileiras no mercado internacional.

Para a Acigames(2013b), os incentivos do governo mostraram-se insuficientes, pouco significativos, superficiais e totalmente alheios à realidade do desenvolvimento do mercado de jogos eletrônico sno Brasil, pois os incentivos criados favorecem apenas uma parcela mínima de desenvolvedores, devido à falta de divulgação, ou pela burocracia envolvida no processo de utilização desses incentivos. 
Apesar dos esforços no fomento à indústria brasileira de jogos eletrônicos, ela ainda enfrenta barreiras à conectividade, ao marco legal, à baixa disponibilidade de profissionais qualificados, ao acesso a financiamentos, ao desenvolvimento de novos modelos de gestão empresarial, e às limitações na transferência de conhecimento (QUERETTE et al., 2012).

Segundo Querette et al. (2012), o setor de jogos eletrônicos possui uma classificação múltipla, localizando-se na interseção entre os setores de tecnologia da informação e comunicação (TIC), de entretenimento e mídia e de bens culturais ou indústria criativa. Devido às múltiplas classificações do setor, o entendimento de suas características e necessidades se torna mais complexo.

A Acigames (2013b) sugere algumas medidas para a consolidação da indústria.

$>$ É necessário que haja um diferencial especial de tributação da folha de pagamento para a economia criativa Para isso,o governo deveria subsidiar ou oferecer bolsas nesse sentido, visto que o capital humano é o principal ativo de empresas dejogos eletrônicose não pode ser onerado.

As empresas precisam de estímulos para trabalhar em conjunto mediante linhas de subvenção específicas para produtos criados por diversas empresas diferentes. É necessário formar especialistas, para evoluir a qualidade do que é feito, para que seja possível criar produtos e serviços de maior qualidade e de maior valor agregado.

> É necessário utilizar a força do mercado consumidor brasileiro para estimular a produção nacional, fazendo com que fabricantes de consoles abram espaço para as desenvolvedoras locais nas suas redes online (PSN, XBLA, etc.), e uma política de participação mínima de conteúdo nacional, como já acontece nas TVs.

A criação de um incentivo à venda jogos $100 \%$ localizados,e estimulando a redução de custos para produções locais e incentivando a localização de jogos estrangeiros. 
Outro fator que deve ser considerado para aumentar a competitividade do setor é a presença de empresas multinacionais de jogos eletrônicos no país, pois essas podem trazer vantagens competitivas para a exportação e internacionalização de produtos e serviços relacionados aos jogos eletrônicos. Segundo a Softex (2005) a presença de multinacionais no Brasil pode acelerar a curva de aprendizagem no setor e também melhorar sua imagem no exterior (LEMOS e QUANDT, 2008).

\subsection{6. \\ Características de políticas de fomento a indústria de jogos eletrônicos em outros países}

A classificação do setor de jogos eletrônicos pode variar de acordo com o país, como na Irlanda e na Austrália, que têm seus setores de jogos eletrônicos incluídos nas políticas de software e comunicação. Também na Austrália e na França o desenvolvimento de jogos eletrônicos está ligado à produção de conteúdo para cinema e televisão (QUERETTE et al., 2012).

Em Querette et al. (2012) foram analisadas várias políticas públicas ligadas à indústria de jogos eletrônicos em diversos países.

Em algumas regiões do Canadá, existem políticas industriais para incentivar o setor de jogos eletrônicos na forma de subsídios, que podem variar de $30 \%$ a $45 \%$ dos salários dos trabalhadores nas empresas. Além disso, também dispõem de empréstimos, subsídios e isenções fiscais para cobrir custos de produção.

Nos EUA, os incentivos variam de estado para estado e normalmente são na forma de isenções fiscais:

Califórnia - subsidia $10 \%$ da mão de obra.

Louisiana,Carolina do Norte, Georgia e Connecticut - 15\% a $30 \%$ de isenção dos custos de produção.

Florida, Havaí, Maine, NovoMéxico, Rhodelsland e Texas - 100\% de isenção fiscal e subsídios para jogos eletrônicos e mídia.

Nova lorque - Subsidia novos empreendimentos com créditos fiscais por empregado.

$\mathrm{Na}$ França, foram criados diversos instrumentos para estimular o desenvolvimento de jogos eletrônicos, tais como: Crédit d'Impôt Jeux Vidéo (CIJV), Fonds d'Aideau Jeux Vidéo (FAJV), La Jeune Entreprise Innovante (JEI), e também outras concessões, pequenos subsídios nacionais, garantias de empréstimos, subsídios de exportação e incubadoras para jogos e multimídia. 
O Crédit d'ImpôtJeuxVidéo (CIJV) é um crédito fiscal de 20\% para os jogos aprovados por um comitê do departamento de cinema francês.

Fonds d'AideauJeuxVidéo (FAJV) é um fundo de apoio aos jogos eletrônicos que subsidia parte da produção de protótipos de jogos.

La JeuneEntrepriselnnovante (JEI) é um prêmio dado em forma de incentivos fiscais para incentivar a inovação em pequenas empresas startups.

$\mathrm{Na}$ França ainda existem também instrumentos locais de incentivo a indústria de jogos eletrônicos. Paris possui o fundo venture capital, que utiliza recursos públicos; o CDC Enterprises, que apóia startups; e um cluster que utiliza recursos públicos para lançar chamadas de apoio para empresas de jogos eletrônicos.

Lyon possui programas de capacitação profissional, apoio para exportação, e um cluster de mídia digital.

Na Coréia do Sul há o Korean Game Development and Promotion Institute (KGDI), que centraliza as políticas de promoção da indústria de jogos eletrônicos sul-coreana. Os focos da KGDI são: o suporte aos jogos online; o desenvolvimento de engines multi-plataforma; e outras tecnologias como a computação gráfica e a animação 3D. Também existem outras políticas que buscam melhorar a cooperação entre institutos de pesquisa, com o intuito de promover a inovação da indústria.

\section{5. Internacionalização de empresas de jogos eletrônicos no Brasil}

No Brasil os altos impostos que influenciam diretamente o aumento da pirataria e a cultura do brasileiro de não pagar pelos jogos acabam tornando o mercado interno de jogos eletrônicos pouco atrativo e por isso as empresas brasileiras buscam nichos menos sensíveis à pirataria, como os serious games, que têm o foco mais voltado para as empresas, ou buscam uma internacionalização precoce (ROCHA, 2010).

Para empresas de jogos eletrônicos não basta que sejam inovadoras, elas também precisam ser rápidas na comercialização dos seus produtos, pois caso isso não ocorra seus produtos podem acabar não sendo comercializadas, devido à velocidade das inovações do setor, e consequentemente, podem acabar sendo substituídos por outros mais novos e melhores. Além disso, essas empresas também necessitam de volume de vendas, para atingir ao menos o ponto de 
equilíbrio (break even). Dessa forma, para aumentar o volume de suas vendas buscam mercados internacionais.

A internacionalização de empresas brasileiras de jogos eletrônicos pode também trazer alguns benefícios indiretos como a exposição internacional da indústria brasileira, a melhoria de suas mercadorias e serviços, com a adequação aos padrões internacionais de qualidade de produto e de processo de produção, e o descobrimento e desenvolvimento de vantagens competitivas.

Parte do potencial brasileiro já está sendo aproveitado no mercado estrangeiro, visto que os profissionais brasileiros têm participação ativa na produção mundial, o que destaca a mão de obra nacional. Porém, devido à falta de capacidade de captação dos profissionais formados no Brasil, uma indústria consolidada, e um mercado consumidor que possa comprar os produtos nacionais, o que ocorre é a saída dos profissionais brasileiros para outros países, ou o estabelecimento de vínculos entre esses profissionais e empresas internacionais por meio de contratos de outsourcing, para produção de elementos específicos para incorporação em projetos maiores ("RELATÓRIO DE INVESTIGAÇÃO PRELIMINAR: O MERCADO BRASILEIRO DE JOGOS ELETRÔNICOS," 2011).No último caso, isso pode ser positivo para a indústria brasileira, pois, além de gerar receita para empresas brasileiras, também gera transferência de conhecimento.

Querette et al. (2012) relatam que devido à dificuldade da indústria brasileira em competir no mercado nacional em função de sua incipiente produção, as desenvolvedoras de jogos eletrônicos brasileiras acabam se voltando para o mercado global, atuando geralmente na prestação de serviços de outsourcing para produtoras internacionais.

Em cidades brasileiras como Rio de Janeiro e São Paulo, há grande quantidade de pessoas jovens com alta qualificação e que falam inglês. Essa mão de obra é capaz de desenvolver todo tipo de atividade, como o desenvolvimento de jogos eletrônicos, por um custo mais baixo do que em países mais desenvolvidos. O Brasil tem o maior número de programadores Java em todo o mundo e é o segundo maior em número de programadores de mainframes (COBOL), segundo a Brasscom. Outro fator que favorece os serviços de outsourcing é a proximidade de fuso horário da América do Sul em relação à América do Norte. Essa proximidade possibilita uma maior interação entre empresas norte americanas e as empresas de outsourcing da América do Sul (HELYAR, 2012). 
Por fim, atualmente a exportação de jogos eletrônicos ficou muito simples, pois por meio de publishers internacionais e ferramentas de distribuição de jogos (Steam, Apple Store, Android Market, e outros), a exportação dos jogos ficou tão simples quanto vender para o mercado interno. 


\section{5 \\ Casos da internacionalização das empresas Aquiris Games e Manifesto Games}

\section{1.}

\section{Aquiris Games}

A Aquiris Games, fundada em 2006, é uma empresa brasileira desenvolvedora de jogos eletrônicos (games) localizada na cidade de Porto Alegre. Com um quadro de 36 funcionários em 2013, a empresa desenvolve jogos casuais ${ }^{i}$ e advergames ${ }^{i i}$ para grandes clientes nacionais e internacionais, entre os quais: Cartoon Network, Warner Bros, Unilever, Embraer, Chevrolet, Gillette, Pepsi, Colgate, Nestlé, Coca-Cola, Globo e Goodyear. Nos últimos quatro anos a empresa lançou mais de 30 jogos, incluindo jogos casuais e advergames

Anexo 1 - Exemplos de Jogos Eletrônicos Desenvolvidos pela Aquiris). Em 2013, a empresa estava prestes a lançar seu primeiro jogo Massive Multi Player (MMP). ${ }^{\text {iii }}$

A Aquiris é especializada no desenvolvimento de jogos através do ecossistema Unity 3D desde 2007. O Unity 3D consiste em uma ferramenta completa para o desenvolvimento de jogos em diversas plataformas, como Windows, Mac, navegadores de internet, Playstation 3, Xbox 360, entre outros. ${ }^{\text {iv }}$

A empresa faturou $R \$ R \$ 1,3$ milhão em 2010, $R \$ 2,6$ milhões em 2011 e $\mathrm{R} \$ 3,2$ milhões em $2012^{\mathrm{v}}$. A Aquiris tem seu foco no mercado internacional, que foi responsável por $90 \%$ de seu faturamento em 2012. A maior parte de suas vendas está concentrada nos EUA, país que responde por cerca de $80 \%$ de seu faturamento total.

\subsection{1.}

\section{Histórico da empresa}

A Aquiris iniciou efetivamente suas atividades em 2007, como desenvolvedora de serviços de maquetes eletrônicas para o mercado imobiliário de Porto Alegre. A empresa foi criada por dois dos seus cinco sócios atuais Amilton Diesel e Maurício Longoni - que buscavam seus clientes no mercado 
imobiliário e ofereciam serviços de construção de maquetes eletrônicas, para servir como instrumento auxiliar à venda de imóveis.

Com as maquetes eletrônicas, os interessados na compra de um imóvel podiam fazer um tour virtual pelo imóvel como forma de "experimentá-lo" antes da visita física e eventual compra. As maquetes eletrônicas produzidas pela Aquiris tinham o diferencial de colocar um personagem dentro do ambiente, para que, por meio dele, as pessoas pudessem visitar o imóvel. Dessa forma, os clientes das imobiliárias poderiam fazer o personagem virtual caminhar pelos cômodos dos imóveis.

Logo após o início de atividades, ocorreu a entrada do terceiro sócio, Israel Mendes, que havia trabalhado até então como redator de uma agência de propaganda em Porto Alegre. Em função de seu conhecimento do mercado de propaganda, ele se deu conta de que a Aquiris tinha potencial para desenvolver jogos que promovessem marcas - conhecidos como advergames, ou seja, jogos eletrônicos desenvolvidos para servirem como ferramentas de divulgação e promoção de marcas, produtos e organizações. Mais ainda, ele se deu conta de que o software de maquetes poderia ser utilizado como base para um jogo. Como relatou Sandro Manfredini:

O Amilton e o Maurício convidaram um terceiro sócio para fazer parte do negócio e, com sua experiência no mercado de comunicação, o Israel Mendes disse: "olha, basicamente o que a gente tem aqui é um jogo, que ainda não tem regras, nem pontuação, mas a capacidade de fazer um jogo praticamente já existe, e o mercado de comunicação está demandando muito isso - jogo como conteúdo para a marca ficar em contato com o seu consumidor por mais tempo".

A partir dessa idéia de Israel Mendes é que a Aquiris começou a trabalhar efetivamente no desenvolvimento de jogos eletrônicos. Paralelamente, outro motivo para a empresa sair do mercado imobiliário era a tendência de construir apartamentos compactos, e a maquete eletrônica acabava evidenciando o pouco espaço interno dos imóveis, não se adequando, assim, às necessidades das imobiliárias.

Como ocorre com a maior parte dos pequenos empreendimentos no setor de jogos eletrônicos, o primeiro jogo era um jogo casual, focado em carros, que foi construído apenas para servir como teste. Logo em seguida, a empresa começou a desenvolver um jogo chamado "Super Vôlei Brasil" encomendado pela Olympikus. Tratava-se de um jogo de vôlei, com os jogadores da seleção brasileira, que expunha bastante a marca Olympikus, patrocinadora da seleção. O sucesso desse desenvolvimento comprovou, para os sócios, que a empresa 
tinha capacidade para desenvolver jogos eletrônicos e, desde então, a Aquiris passou a trabalhar apenas com esse tipo de produto.

Em 2007, os sócios da Aquiris tomaram conhecimento de uma promoção feita pela rede de fast-food Burger King, que havia sido premiada como case mais criativo no festival internacional de propaganda de Cannes. A promoção consistia de jogos com os personagens da marca, que podiam ser adquiridos por seus clientes na compra de um lanche barato. Esses jogos podiam ser jogados em consoles Xbox, da Microsoft. O sucesso internacional dessa experiência, segundo Manfredini "acabou inspirando os criativos brasileiros a buscar esse tipo de solução também para suas marcas". Como o mercado brasileiro de propaganda estava aquecido e a Aquiris já dispunha de tecnologia 3D que funcionava diretamente nos navegadores de internet, a empresa passou a investir mais em advergames.

Entre o final de 2007 e o início de 2008, um investidor-anjo, com relacionamento anterior com o sócio Israel Mendes, adquiriu uma participação na empresa, passando a ser o seu quarto sócio. Apesar de ser um investidor com recursos limitados, o aporte de recursos permitiu à Aquiris, na época, estabelecer sua primeira sede, comprar equipamentos novos e contratar um programador.

De 2008 até 2010 a empresa se dedicou ao desenvolvimento de advergames para o mercado brasileiro. No entanto, a partir de 2010, a Aquiris passou a participar de eventos internacionais voltados para o setor de jogos eletrônicos, o que a colocou em contato com potenciais clientes no exterior, dando início a seu processo de internacionalização.

Em 2012, tornou-se sócio da empresa Raphael Lopes Baldi, que havia ingressado como programador no início das atividades da Aquiris.

Para Sandro Manfredini, a qualidade técnica dos produtos e serviços desenvolvidos pela empresa é o principal diferencial da Aquiris, aliada a um engine Unity, que permite o desenvolvimento de jogos eletrônicos em diversas plataformas e que também é muito difundida no mercado mundial. A Aquiris está entre as melhores desenvolvedoras de jogos eletrônicos que utiliza o sistema Unity. 


\subsection{2.}

\section{Perfil dos dirigentes}

Amilton Guilherme Diesel é sócio-fundador e Diretor de Arte da Aquiris. É profissional de computação gráfica, com experiência anterior em design arquitetônico.

Maurício Longoni, um dos dois sócios que fundaram a empresa, ocupa o cargo de Diretor de Tecnologia. Ele tem participação ativa nas negociações internacionais, principalmente no que se refere aos aspectos técnicos.

Israel Mendes é o Diretor de Criação. Embora também acompanhe as negociações internacionais, tem menor envolvimento, pois está mais voltado para desenvolvimento de projetos.

Sandro Manfredini ocupa o cargo de Diretor Comercial. É proveniente da área de propaganda. Já havia trabalhado em agências de propaganda, entre as quais a Cubo, agência brasileira pertencente a um grupo internacional. Nesta agência, atuou no desenvolvimento de negócios internacionais, em função de relações da Cubo com agências no México, nos Estados Unidos e em Portugal. $\mathrm{Na}$ Aquiris, ele tem o papel principal na realização de negociações internacionais.

\subsection{3. \\ Processo de internacionalização}

O processo de internacionalização da Aquiris é bastante recente, tendo se iniciado em 2010.

Em uma feira internacional, a empresa chamou a atenção da companhia desenvolvedora do ecossistema Unity, utilizado pela Aquiris desde 2007. No evento, a Unity Technologies (Anexo 2 - Unity Technologies) convidou a Aquiris para desenvolver o projeto de um jogo de demonstração (jogo demo) de como utilizar todos os recursos da nova versão do sistema Unity (Unity 3.0). A experiência acabou sendo muito importante para a Aquiris, pois serviu para aproximar sua própria equipe da equipe de desenvolvedores da Unity Technologies. Assim, foi desenvolvido o jogo demo, chamado Unity Bootcamp, que passou a ser instalado juntamente com o sistema Unity 3.0, ajudando assim a promover a Aquiris entre os desenvolvedores de jogos eletrônicos do mundo que também utilizavam o ecossistema Unity 3.0.

Em 2011, quando Sandro Manfredini entrou como sócio na empresa, o seu primeiro dia de trabalho como diretor comercial foi na Game Developers 
Conference, em San Francisco, EUA.No evento, a Aquiris colocou um banner sobre o projeto com a Unity Technologies,que chamou a atenção de participantes da feira. Segundo Manfredini, foi possível ver o impacto positivo do projeto Unity Bootcamp para a Aquiris. A experiência gerou um convite feito por um publisher (distribuidora de jogos eletrônicos ${ }^{\text {vi }}$ ), a Aerea Games, para a Aquiris desenvolver um game shooter (jogo de tiro vii).

No entanto, a parceria com este publisher não frutificou. Manfredini relatou os problemas ocorridos da seguinte forma:

É uma história um pouquinho mais longa... A empresa que nos fez o convite para desenvolver o game no meio do caminho desistiu do projeto. Ela tinha oferecido muito poucos recursos para a Aquiris fazer o projeto. Nós tínhamos aceitado, mas nos demos conta de que era impossível. Voltamos a eles para negociar mais verba, mas eles já não tinham isso como prioridade.

Para tentar reverter os problemas gerados pelo contrato feito com a Aerea Games, a Aquiris comprou os direitos da parceira sobre o jogo shooter, e os revendeu para o Publisher Rumble, estabelecendo assim uma nova parceria. A partir da experiência adquirida, ao negociar um contrato com a nova parceira, a Aquiris foi mais cautelosa e contratou um advogado americano para acompanhar todo o processo. A contratação do advogado, apesar de ter gerado um custo alto para a empresa, fez com que diversas cláusulas que beneficiavam muito mais a Rumble que a Aquiris fossem retiradas, evitando assim que a Aquiris ficasse novamente em posição pouco favorável.

Posteriormente, a participação da Aquiris em feiras internacionais permitiuIhe realizar diversas parcerias com grandes empresas multinacionais, como Cartoon Network e Warner Bros.

\subsection{4.}

\section{Características do processo de internacionalização}

Com toda a sua estrutura técnica e gerencial baseada no Brasil, desde que a Aquiris se transformou em criadora de jogos eletrônicos, o maior foco da empresa passou a estar no mercado internacional. Isso se deve principalmente ao fato de muitos mercados para jogos eletrônicos em outros países estarem mais fortes e estabelecidos do que o mercado brasileiro e pela facilidade de distribuir jogos por meio de publishers, com lançamento simultâneo em diversos mercados mundiais. Como explicou Sandro Manfredini:

Hoje em dia, não tem porque lançar um game só no Brasil. Com as plataformas digitais o mundo todo está ao nosso alcance muito mais facilmente do que em quando os games estavam restritos a consoles, ou a jogos de caixinha, que tinham 
distribuição física. Com o mundo digital e as plataformas digitais, não temos porque nos limitar a um mercado geográfico único. Então, fazer parte dessa network internacional é extremamente natural e necessário. E como a empresa usa engines [motores de jogos] internacionais, não tem como ela não estar presente fora do Brasil. Eu insisto: se uma empresa de games quer crescer, ela não tem como ficar restrita ao mercado nacional.

A atuação da Aquiris está totalmente voltada para o mercado norteamericano, pois além de ser o maior mercado do mundo, as grandes empresas de jogos eletrônicos buscam se fixar no país. A presença em feiras nos Estados Unidos também funciona como meio para atuar em outros mercados. Segundo Sandro Manfredini, os EUA funcionam como centro mundial para a comercialização de jogos eletrônicos, com grande parte das empresas de jogos eletrônicos do mundo buscando o país para fazer negócios entre si:

O nosso mercado base é sempre o norte-americano. Usamos os Estados Unidos como ponte para qualquer outro mercado, por enquanto. Toda a indústria de jogos eletrônicos que ainda podemos explorar - fora a China, que é um mercado particular - podemos alcançar via o mercado americano.

Com base nessa estratégia, a Aquiris já negociou com a empresa Square Enix, do Japão, mas por meio do escritório dessa empresa no México. Criou parcerias nos Estados Unidos com as empresas Aerea Games, de origem vietnamita, e com a Unity Technologies, de origem dinamarquesa (ambas sediadas nos Estados Unidos).

A direção da Aquiris entende que poderia conseguir novas oportunidades em outros países, além dos EUA, porém atualmente não dispõe de recursos para investir na participação em eventos em muitos lugares, e como as feiras nos EUA atraem empresas de jogos eletrônicos de todo o mundo, a Aquiris acaba focando exclusivamente na participação nos principais eventos norteamericanos, como explicou Manfredini:

Há uma feira no Japão. Gostaríamos de ir? Sim, gostaríamos.Talvez gerasse negócios diretos lá? Talvez. Mas são viagens ainda mais caras, que têm que competir com as viagens que a gente já faz para os Estados Unidos. Então, se temos que escolher um lugar, se não podemos ir para todos [os lugares], conseguimos atingir esses outros mercados via Estados Unidos.

Como a empresa não possui instalações físicas nos Estados Unidos, os dirigentes da Aquiris buscam estar presentes naquele mercado participando de três eventos internacionais por ano, sendo dois deles em San Francisco, que são a Game Developers Conference e a Game Connection. O terceiro evento, a Unite Conference, é um evento mais técnico do que os outros, e tem por finalidade reunir os desenvolvedores do sistema Unity no mundo. Para 
representar a Aquiris nos dois primeiros eventos costumam ir o diretor comercial, Sandro Manfredini, o diretor de tecnologia, Maurício Longini, e o diretor de criação, Israel Mendes. Já para a Unite Conference vão Maurício Longini e o diretor de arte técnica, Amilton Diesel. A participação da Aquiris nesses eventos é custeada pela empresa, com exceção da participação na Game Connection que, em parte, tem sido custeada pela Apex-Brasil.

Por exemplo, em agosto de 2012, na Unite Conference viii, em Amsterdam, Amilton Diesel realizou a palestra Transcending Unity's Frontiers: from game development tool to cross-media platform. Nesta palestra, apresentou alguns dos desafios na criação deadvergames usando o sistema da Unity e as soluções encontradas pela Aquiris. Um dos projetos apresentados foi um advergame (The Secret of Magic Valleys) desenvolvido para a Coca-Cola para promover a marca Kapo de sucos infantis da Del Valle. Outro jogo apresentado neste congresso foi desenvolvido para a Cartoon Network - Dragon: Riders of Berk - uma franquia da Dreamworks, que tinha grande complexidade gráficaix ${ }^{\text {. }}$.

É indispensável para a Aquiris a participação em eventos internacionais, pois é onde a empresa tem a oportunidade de mostrar seus produtos e serviços. Nas palavras de Sandro Manfredini:

É, de fato, a nossa oportunidade de mostrar o que a Aquiris faz, o que a empresa tem de produto, de prestação de serviço. É a nossa maior fonte de prospecção internacional. É claro que são contatos rápidos e, portanto, temos todo o trabalho de dar continuidade aos mesmos depois, a partir daqui do Brasil. Mas, não estar presente nesses eventos torna inviável consolidar novos negócios.

Em feiras internacionais, como a Game Connection, existem dinâmicas voltadas para a criação de negócios, em que uma empresa convida outras empresas para reuniões de aproximadamente 30 minutos. Essas reuniões são utilizadas para os participantes apresentarem seus trabalhos e verificarem a possibilidade de desenvolvimento de negócios conjuntos.

Após uma feira internacional, os dirigentes da Aquiris costumam ficar por mais uma semana nos EUA para dar seguimento às reuniões mais promissoras e também para estabelecer contatos importantes para a empresa. Em 2012, por exemplo, os dirigentes da Aquiris foram conhecer pessoalmente o advogado que os ajudou no desenvolvimento do contrato com o Publisher Rumble, e foram também à sede de uma das maiores empresas de jogos eletrônicos do mundo, a Electronic Arts, com mais de 9.000 empregados, sediada na Califórnia. Manfredini detalhou: 
Nós fizemos contato com a ElectronicArts, nos Estados Unidos, na tentativa de desenvolver games em parceria com eles e fomos convidados a conhecer um estúdio deles em Estocolmo, mas, de novo, sempre tendo como base central os Estados Unidos, porque a ElectronicArts é americana. Então, apesar de termos ido para outros países, nosso foco comercial estava nos Estados Unidos.

Outra forma de identificar oportunidades de negócios utilizada pela Aquiris é por meio de sites especializados, como por exemplo, o site gamesutra.com, que é um portal de notícias sobre jogos eletrônicos com foco nas tendências de mercado e oportunidades de negócios na área.

Os canais de distribuição da empresa são atualmente os seus parceiros, como Cartoon Network e Rumble, que são publishers, ou seja, são responsáveis pela distribuição dos jogos produzidos pela Aquiris no mundo. Nesse arranjo, a Aquiris produz o jogo ou parte do jogo e os publishers fazem a promoção e a distribuição. Pode acontecer de a empresa publisher também participar da produção do jogo, caso em que a Aquiris passa a ter o papel de coprodutora. Manfredini explicou:

Nossos jogos têm publishers. A Cartoon Network, e a Rumble, são nossos canais de distribuição, por exemplo. É através dessas empresas, que, basicamente, estão hoje nossos jogos, nas plataformas IOS e Android, no Facebook, em PCs, em browsers...

As parcerias também geram importante aprendizado para a empresa, como no caso da relação com a Rumble:

A Rumble é um publisher, mas também é um desenvolvedor. Eles desenvolvem games internamente também. Além de terceirizar com a Aquiris esse desenvolvimento. Terceirizar não é bem a palavra, porque nós somos sócios no projeto, mas eles não desenvolvem só internamente, desenvolvem com estúdio fora, que é o nosso caso, que somos nós. E eles têm um produtor executivo para o projeto, que foi contratado especificamente para desenvolver esse projeto conosco. Então, há troca de experiência sobre isso, há troca de experiência sobre estratégias de monetização no jogo. Porque, como eles têm outros jogos, eles têm estratégias $X, Y, Z$ para aqueles jogos e acabam compartilhando isso conosco para implementarmos no nosso jogo também... E o benefício para eles é que nós entregamos tecnologia, principalmente bons produtos. E eles acabam aprendendo algumas coisas conosco.

Em relação ao estabelecimento de preços para seus produtos e serviços, a empresa toma como base seus custos diretos e indiretos. Para todos os projetos são estabelecidos preços levando em consideração os profissionais designados, os recursos técnicos necessários e o percentual da estrutura da empresa que será alocada. Dentro desse cálculo também são considerados os impostos que, segundo Manfredini, são menores quando o serviço é prestado pela Aquiris no 
exterior (em torno de 11\%) do que quando os serviços são prestados no Brasil (acima de 18\%).

A empresa utiliza os preços da concorrência como parâmetro de comparação no processo de precificação de seus serviços, mas apenas nos casos em que percebe que pode aumentar sua lucratividade. Ou seja, a Aquiris não considera baixar seus preços para competir com outras empresas, pois isso, segundo Manfredini, poderia gerar problemas: "Nossa consciência quanto ao aspecto financeiro é muito grande. Depois de alguns erros, entendemos que não se pode trabalhar para gerar um problema financeiro."

Em suas atividades de pós-venda, a Aquiris busca manter as relações com seus clientes para preservar as parcerias e, com isso, criar oportunidades para desenvolver novos projetos. Um exemplo dessa estratégia foi a visita dos dirigentes da Aquiris à Cartoon Network em Atlanta, nos EUA, depois da participação em uma feira internacional, com o objetivo de estreitar os laços entre as duas empresas. Nas palavras de Manfredini:

Quando fomos nesse início de ano [2013] aos Estados Unidos, fomos a Atlanta especificamente para fazer uma visita à Cartoon Network. Fizemos questão de ir lá, porque tínhamos tido um caso bastante bom com o jogo que desenvolvemos no segundo semestre do ano passado. Então, foi muito importante colher esse feedback, conhecer pessoas novas da equipe, e assim por diante.

Existe também uma preocupação da empresa em manter as relações criadas com seus clientes, mesmo que sejam clientes antigos e para quem já não desenvolva mais trabalhos. Nesse sentido, a Aquiris busca mantê-los informados sobre seus trabalhos mais recentes e os que se encontram em fase de desenvolvimento.

Com relação à concorrência, na percepção de Manfredini, não há muitas empresas no Brasil trabalhando no mesmo formato da Aquiris. A Aquiris está sempre em busca de parcerias internacionais, enquanto que a maioria das empresas brasileiras não apresenta muita disposição para fazer coproduções com empresas no exterior. Há, porém, exceções. Algumas empresas se assemelham à Aquiris em alguns aspectos, como é o caso da llusis, de Belo Horizonte, que recentemente recebeu investimentos e que também vai para a feira Game Connection em busca de clientes internacionais; e da Hoplon de Florianópolis, que, além de desenvolver jogos, também faz o trabalho de publisher. 
A Aquiris não faz estudos de mercado para definir sua atuação no exterior. A empresa desenvolve apenas planejamento de curto prazo, no mês de dezembro de cada ano, para serem implementados em março do ano seguinte, com foco nos eventos internacionais que acontecem naquele mês nos EUA. Assim, é no mês de dezembro que os dirigentes decidem qual será a estratégia de atuação nas feiras, ou seja, eles irão avaliar tudo que foi feito durante o ano em curso e, com base nessa avaliação, criarão o portfólio da empresa que será utilizado para buscar novos negócios.

\subsection{5.}

\section{Barreiras à internacionalização}

A falta de experiência em contratos com empresas internacionais é uma das barreiras à internacionalização de pequenas empresas de jogos eletrônicos. A experiência da Aquiris com a Aerea Games mostrou aos sócios a necessidade de utilizar um advogado local para obter condições favoráveis na negociação.

Segundo Manfredini, para que uma empresa brasileira tenha melhores condições de negociar contratos no exterior é preciso não somente experiência, mas também maior "saúde financeira". Para ele, os contratos são piores para empresas de jogos eletrônicos brasileiras porque a indústria brasileira ainda é muito pequena e, consequentemente, encontra-se em desvantagem nas negociações internacionais:

Para negociar com players internacionais, o ideal é ter saúde financeira, boa o suficiente para poder exigir um pouco mais dos contratos. Porque se a empresa não tem essa saúde financeira, acaba fechando contratos que não são os mais justos. [...] Temos a clara percepção de que, enquanto a indústria brasileira não for grande o suficiente, não tiver fôlego suficiente, vai fazer contratos não muito bons. Isso vai acontecer a menos que se tenha mais fôlego para negociar um pouco mais de justiça com um mercado que é muito maior.

Na percepção de Manfredini, a direção da empresa passou a ter maior consciência de suas possibilidades e limitações. Em função disso, optava, muitas vezes, por projetos menos lucrativos, porém de menor risco. Por exemplo, a Aquiris estava desenvolvendo um projeto com a Cartoon Network, em formato de coprodução, com base em uma série de desenhos animados amplamente conhecida pelo público infantil, chamada "Ben 10". O jogo atualmente já está disponível na internet, porém ainda está sendo desenvolvido para as plataformas IOS e Android para dispositivos portáteis. Manfredini esclareceu: 
Estamos fazendo um jogo com um parceiro que tem uma série extremamente famosa, que tem uma capacidade de promoção incrível, e nós não estamos investindo todo o valor do projeto, estamos investindo uma parcela. É claro que a parcela dos lucros [para a Aquiris] vai ser menor também, mas o risco é muito baixo. Se eu tentar criar um jogo como esse do nada, eu vou gastar uma grana desenvolvendo o jogo - que não é fácil - e depois ainda vou ter que ter uma grana, quem sabe, ainda maior, para promover esse jogo mundialmente.

Uma grande dificuldade enfrentada pela empresa está relacionada aos seus gastos com impostos, principalmente com relação aos encargos trabalhistas que tornam a mão de obra no Brasil muito cara, aproximando-se dos custos da mão de obra nos EUA, uma das mais altas do mundo no setor. Os altos custos da mão de obra no Brasil, combinados à distância geográfica, acabam tornando a Aquiris pouco atraente para alguns parceiros ou clientes no exterior. De acordo com Manfredini:

O custo da Aquiris não é baixo, então, quando estamos negociando um contrato fora do Brasil, há ainda a dificuldade da distância, e essa distância, não sendo ajudada por um custo muito mais baixo, torna ainda mais difícil para o parceiro de fora nos contratar ou nos ter como parceiro ideal.

Para contornar esses problemas, a empresa busca desenvolver vantagens competitivas relacionadas à qualidade técnica e à entrega dos produtos dentro do prazo contratado, que acabam sendo diferenciais importantes para conseguir parceiros fora do Brasil.

Outra dificuldade para a exportação de jogos eletrônicos para os EUA está relacionada às altas taxas que as empresas brasileiras têm que pagar sobre os royalties recebidos nas vendas diretas dos seus jogos nos EUA. Um acordo entre Brasil e Estados Unidos prevê que $30 \%$ dos royalties fiquem retidos nos EUA, sendo que esse percentual pode variar muito de um país para outro. Por exemplo, enquanto para as empresas brasileiras a taxa é de $30 \%$, a retenção para as empresas inglesas que comercializam no mercado dos Estados Unidos é de apenas $2 \%$.

Finalmente, o entrevistado fez especial menção à falta de estudos no Brasil e de treinamento para a formação de empreendedores do setor:

Quanto ao negócio de games não existe muito estudo ou muita preparação dos empresários para isso, aqui no Brasil. Então, basicamente, é preciso fomentar ao máximo a troca de experiências, [...] a formação do empresário, do empreendedor brasileiro de games para negócios. 


\subsection{6. \\ Facilitadores para a internacionalização.}

A direção da Aquiris reconhece o papel desempenhado pela ApexBrasil em auxiliar a empresa em sua participação em eventos internacionais, custeando parte das despesas.

Recentemente a ApexBrasil uniu-se à Associação Brasileira dos Desenvolvedores de Jogos Digitais (Abragames), com a expectativa de que sejam criadas feiras no Brasil. seguindo o mesmo modelo de feiras internacionais como a Game Connection,trazendo grupos de publishers e clientes internacionais para fazer rodadas de negócios no país. A criação de feiras como essas deve trazer oportunidades para empresas dejogos eletrônicos, principalmente as que ainda são muito pequenas, que não poderiam arcar com os custos de participação em feiras internacionais.

A empresa também está ligada a duas associações brasileiras relacionadas a jogos eletrônicos, a Abragames e a Acigames, sendo que a Abragames tem uma participação mais próxima à Aquiris, pois também está trabalhando junto com a Apex.

A Abragames e a Apex estão desenvolvendo o projeto Brazilian Game Developers, que busca divulgar informações sobre o mercado de jogos eletrônicos nacionais e também para promover as empresas locais no exterior pela internet. Esse projeto tem como objetivo promover internacionalmente os jogos eletrônicos criados por estúdios brasileiros, fechando negócios para exportar os títulos, elevando o nível de negociação das empresas locais com companhias estrangeiras e capacitando estas empresas para o mercado global. ${ }^{\mathrm{X}}$

Para Manfredini, as instituições governamentais e agências como a Apex poderiam também auxiliar as empresas desenvolvedoras oferecendo serviços de consultoria para a elaboração de contratos internacionais. Em sua opinião, poucas empresas desenvolvedoras de jogos eletrônicos podem arcar com investimentos para elaboração de contratos, pois são investimentos altos demais para a maior parte delas:

É muito caro para uma empresa sozinha bancar. Nós, por exemplo, investimos 40 mil reais numa consultoria jurídica para fazer o contrato com a Rumble. Então, eu acho que, se pudéssemos contar com alguma ajuda, que ainda não temos, seria essa: a de ter uma assessoria jurídica especializada nisso, mais acessível, talvez por meio de um programa da Apex. [...] É por falta de experiência com contratos internacionais, que todo mundo acaba aceitando o que vem, porque não tem 
condições de contratar uma consultoria para que essa consultoria diga: "olha, essa cláusula aqui, ela vai te trazer essa, essa e essa consequência”, entende? [...] Então, são coisas que matam a indústria, ainda no começo. Fazendo maus contratos, acaba morrendo ainda mais cedo.

Para o entrevistado, o governo brasileiro também poderia ajudar as empresas brasileiras disponibilizando verbas de fomento e linhas de crédito para a área de desenvolvimento de software e jogos eletrônicos, pois as linhas de crédito existentes, em sua grande maioria, exigem garantias formais e as empresas de software e jogos eletrônicos que estão iniciando suas atividades não dispõem de tais garantias:

O que a indústria brasileira de games está precisando é de verba de fomento, linhas de crédito específicas para essa área. Eu acho que deve envolver até desenvolvimento de software, porque game também não deixa de ser software, $e$ pode estar no mesmo barco.

\subsection{7. \\ Perspectivas futuras}

A Aquiris é uma pequena empresa em uma indústria ainda pouco desenvolvida no Brasil, mas que consegue competir no mercado internacional. Isso é uma evidência deque existe espaço para crescimento nessa indústria, em que pequenas empresas ainda podem competir e criar parcerias com empresas de grande porte, mesmo que com algumas desvantagens. No entanto, a Aquiris, apesar da sua qualidade técnica, não está voltada para o crescimento: suas estratégias de atuação são de curto prazo, mostrando maior preocupação em correr menos riscos e sobreviver no mercado.

A principal diretriz de negócio da empresa é a de continuar buscando coproduções menos arriscadas, como a que está sendo desenvolvida com a Cartoon Network. Atualmente a empresa está mais focada nos projetos em andamento, e por isso não está procurando se expandir. Nas palavras do diretor comercial:

Hoje a empresa não está crescendo mais, não estamos buscando mais negócios. Até por acreditarmos ser necessário ter foco nesses negócios que a empresa já desenvolveu. Basicamente, nossa diretriz hoje é de buscar mais coproduções como essa que estamos fazendo com o Cartoon Network. Um negócio que nos gere menos riscos no momento. 
Essa estratégia de consolidação de sua atuação internacional atende a duas vertentes mandatórias para a empresa. A primeira diz respeito à sua posição competitiva no mercado, disputado por empresas que compõem essa indústria totalmente globalizada e, a segunda, à percepção de seus dirigentes de que a internacionalização da Aquiris obriga a, constantemente, buscar elevar a qualidade técnica de seus produtos e a gerenciar a organização com o profissionalismo exigido pelo mercado internacional, como afirmou Manfredini:

Temos que buscar aperfeiçoamentos técnicos e de gestão, no sentido de modelo de negócio, que é uma coisa que vem mudando muito. O que antes era um jogo de caixinha passou a ser um jogo vendido em plataformas internacionais, depois passou a ser jogo freeto play. Hoje em dia, a maior parte dos jogos é gratuita, mas temos que ter uma estratégia boa para monetizar, com a venda de itens dentro do jogo. Então, é muito importante beber da experiência internacional, porque nós [no Brasil] estamos sempre um passo atrás.

\section{2. \\ Manifesto games}

Localizada em Recife, a Manifesto Games é uma empresa de entretenimento digital, que atua no segmento de jogos eletrônicos, tendo iniciado suas atividades em 2005. No início de suas atividades, a empresa contou com o apoio da pré-incubadora de empresas Recife BEAT - Base para Empreendimentos de Alta Tecnologia ${ }^{\mathrm{xi}}$, cuja operação é coordenada pelo C.E.S.A.R. - Centro de Estudos e Sistemas Avançados do Recife ${ }^{\mathrm{xii}}$, do agente Softex em Recife (por meio de programa que apoia a realização de ações de empreendedorismo e promove a qualidade de software) e do Centro de Informática da Universidade Federal de Pernambuco.

A empresa foi criada com o propósito de desenvolver produtos, inicialmente browsergames e, depois, downloadable casual games, com foco principalmente no mercado internacional. Após alguns anos de atividade, a empresa passou a trabalhar também na prestação de serviços associados a jogos, com produção para terceiros no Brasil e no exterior.

Os principais serviços desenvolvidos pela empresa são:jogos eletrônicos para marcas ${ }^{\mathrm{xiii}}$, "gameficação"xiv e outsourcing ${ }^{\mathrm{xv}}$ (terceirização). Das três áreas de prestação de serviços, a de jogos eletrônicos para marcas e a de "gameficação" se destinam ao mercado brasileiro, enquanto a de outsourcing é realizada para empresas no exterior.

O desenvolvimento de jogos eletrônicos para marcas, dentro da categoria advergames, está ligado a uma atividade promocional das empresas, que oferecem jogos a seus clientes com o objetivo de construir e desenvolver a 
relação do cliente com a marca. Já no caso da "gameficação", a empresa atua revendo determinados serviços e sistemas de empresas, buscando transformálos em experiências mais prazerosas para seus clientes e funcionários, por meio da criação de jogos eletrônicos. Na área de outsourcing, a Manifesto atua em parceria com empresas estrangeiras, como parte da equipe de desenvolvimento de um game. Neste caso, o trabalho é desenvolvido à distância, exigindo constante interação com os parceiros.

A estrutura da empresa contava, em 2013, com 25 funcionários no Brasil. Em torno de $10 \%$ a $15 \%$ do seu faturamento total, nos últimos anos, era proveniente de exportação de serviços para clientes internacionais.

\subsection{1.}

\section{Perfil dos dirigentes}

A Manifesto Games foi fundada em 2005 por Vicente Vieira Filho (atual diretor de negócios), na época com 22 anos de idade, Leonardo Gesteira Costa e Marco Túlio Caraciolo Ferreira Albuquerque (atual diretor de produção), os dois últimos então com 21 anos.

Todos os sócios tinham formação em ciência da computação, na Universidade Federal de Pernambuco (UFPE). Os fundadores também tiveram três anos de experiência profissional, onde criaram e desenvolveram diversos tipos de aplicações para o mercado de jogos para computador, web e desktop. Durante esse período construiu-se o vínculo com professores do Centro de Informática da UFPE.

Apesar de Vieira Filho já ter atuado, antes da criação da Manifesto, na empresa Jynx Playware, que também desenvolve jogos eletrônicos, não teve experiências relacionadas à gestão de empresas, pois atuava em áreas técnicas de produção de jogos. Toda a sua experiência de atuação em gestão vem da Manifesto Games e das empresas Games e Joy, que foram fundadas posteriormente com a participação da Manifesto Game Studio. Vieira Filho fez o mestrado na UFPE em inteligência artificial para jogos eletrônico se encontravase, na ocasião da entrevista, cursando o doutorado.

\subsection{2.}

\section{Histórico e processo de internacionalização}

O histórico da Manifesto Game Studio não pode ser dissociado de seu processo de internacionalização. Desde o início de suas atividades, os sócios 
tinham a visão de explorar os mercados internacionais, pois o mercado brasileiro dejogos eletrônicos, em 2005, ainda era muito pequeno e pouco desenvolvido. Vieira Filho salientou:

A Manifesto sempre teve um pé muito mais no exterior do que no Brasil. Hoje em dia é que nós estamos modificando um pouco esse cenário... Mas a Manifesto, em 2005, já nasceu com a visão de atuar no mercado internacional. Em diferentes regiões do mundo, diferentes idiomas... É uma experiência muito gratificante.

Assim, desde a criação da empresa buscaram parceiros fora do Brasil para lançar seus browser games, que foram os primeiros produtos criados na Manifesto. Trata-se de jogos eletrônicos desenvolvidos para serem jogados diretamente por meio de um navegador (browser), que foram comercializados pela empresa até 2008. Para comercializar seus jogos na internet, a Manifesto criava parcerias com portais de jogos eletrônicos online, que disponibilizavam seus browser games para os usuários. Encontravam-se entre seus principais parceiros grandes portais de jogos online como Miniclip, Kongregate e Ugoplayer.

A partir dessas experiências com os browser games é que, ao final de 2008, a Manifesto decidiu passar a produzir jogos mais robustos (com maior complexidade e recursos gráficos superiores), os chamados downloadable casual games, que são jogos que, para serem jogados, precisam ser "baixados" da internet e instalados em um computador PC ou Mac. Segundo Vieira Filho, os downloadable games "atingem um público muito específico, geralmente mulheres acima de 35 anos".

O modelo de negócio utilizado para comercializar esses jogos, também via portais, é o chamado shareware, que permite o download gratuito do game por qualquer usuário, porém com restrição no tempo de uso, ou seja, após determinado período de tempo, o jogo é automaticamente travado e o usuário é convidado a comprar a versão completa. Desse modo, o usuário tem a oportunidade de experimentar o jogo antes de realizar a compra.

Segundo Vieira Filho, o modelo shareware faz muito sucesso e cresce, a níveis globais, de $40 \%$ a $45 \%$ ao ano. Atualmente, os downloadable games da Manifesto já foram lançados em mais de trezentos portais de jogos eletrônicos e em onze idiomas diferentes, sendo o seu jogo Fruits Inc. (10.3 Anexo 3 - Jogos Eletrônicos Desenvolvidos pela Manifesto Games), lançado em 2009, o de maior sucesso, tendo atingido a marca de 3,5 milhões de downloads em 2013. 
$\mathrm{Na}$ fase dos downloadable games, a Manifesto firmou parcerias com grupos maiores, como Big Fish Games, Game House, iWin, Boonty, Nextep Media e Atrativa (brasileira). Essas parcerias permitiram ampla distribuição de seus jogos, tendo uma abrangência global, porém com foco maior no mercado dos Estados Unidos.

Durante a primeira fase - a dos browser games - a empresa tinha como alvo países ocidentais, porém, com os downloadables games, o mercado asiático também passou a ser explorado. As empresas Boonty e NextepMedia foram os parceiros que ajudaram a entrada da Manifesto nos mercados chinês, japonês e sul coreano. Já para o mercado europeu, foi feita uma parceria com o portal Alwar, de origem russa, com forte atuação naquele continente.

Em 2008, a Manifesto participou de um projeto de criação de um Massively Multiplayer Online Games (MMOG) ${ }^{x \mathrm{xi}}$, que combinava aprendizado a jogos eletrônicos. Em 2013, esse MMOG encontrava-se em funcionamento nas cidades do Rio de Janeiro e de Recife, sendo utilizado por cerca de dois milhões de alunos.

No final de 2011, os empreendedores desenvolveram um plano para a exploração do mercado brasileiro, que começava a oferecer maiores oportunidades para a indústria de jogos, graças ao momento econômico favorável que o Brasil estava vivendo. Dessa forma, em 2012, a Manifesto passou a produzir jogos visando o mercado brasileiro e também a atuar na prestação de serviços no mercado doméstico. No Brasil, a Manifesto trabalhava principalmente na linha de jogos para marcas e gameficação, em que seus principais concorrentes eram empresas como Webcore Games, Insólita Studios, Aquiris, Jynx Playware, Interama e Sioux.

A partir de 2012, quando a empresa passou a atuar também na prestação de serviços, foi necessário utilizar uma equipe interna de vendas para prospectar clientes pelo mundo, apresentando os serviços da Manifesto Game Studio. Essa prospecção era feita por meio de contatos pessoais, participação em feiras setoriais e eventos de jogos eletrônicos.

Apesar de a Manifesto ter passado a atuar com mais força no mercado interno nos últimos anos, e o mercado externo, que antes representava praticamente $100 \%$ do faturamento da empresa, ter reduzido sua participação para $10 \%$ a $15 \%$, os dirigentes da Manifesto continuavam entendendo que a 
atuação no mercado internacional era de absoluta importância por vários motivos.

Em primeiro lugar, a atuação internacional permitia à Manifesto permanecer atualizada sobre o que havia de mais inovador e avançado tecnologicamente no mercado mundial. Por meio de seus clientes de outsourcing, a empresa participava de projetos com grandes empresas da indústria de jogos eletrônicos mundial, como a Zynga, uma das maiores desenvolvedoras de jogos do mundo para o Facebook, e a Disney, grande referência no desenvolvimento de jogos eletrônicos. Vieira Filho declarou:

Trabalhando com a Zynga, com a Disney, estamos falando de grandes empresas que são referências em todo mundo. Então, participar de seus projetos e fazer parceria com eles, beber dessa fonte de inspiração e conhecimento, é essencial para nós nos mantermos em termos de vanguarda tecnológica, muito mais ainda no Brasil.

Em segundo lugar, a atuação da empresa no exterior era utilizada, no Brasil, como comprovação de qualidade e experiência:

Estar lá fora nos permite ter grandes cases interessantes e clientes de peso, para nos ajudar em outras áreas. Então, nas áreas em que trabalhamos aqui no Brasil, de gameficação e de games para marcas, ajuda bastante, na apresentação da empresa, para atestar nossa qualidade e experiência.

Em terceiro lugar, a desvalorização recente do real em relação ao dólar também fez com que os produtos e serviços exportados ficassem mais valorizados, tornando mais atrativas as atividades no mercado internacional.

Por último, a Manifesto passou por diversos processos de aprendizagem em sua atuação no exterior. Aprendeu muito em termos de relacionamento e networking. Aprendeu sobre os principais modelos de negócios da indústria de jogos eletrônicos. Para Vieira Filho, adquirir esses conhecimentos foi de extrema importância para a empresa, tanto para a exportação de produtos, quanto para a prestação de serviços: "É uma expertise extremamente válida. Acredito que poucas empresas saibam bem isso no Brasil."

Assim, o aprendizado passou a ser um diferencial para a empresa, em sua atuação tanto no exterior quanto no Brasil. 
No entender de Vieira Filho, a atuação internacional também alterou as percepções dos próprios funcionários da empresa, que tinham uma visão de que produtos e serviços desenvolvidos fora do Brasil eram de melhor qualidade. Foi possível verificar que não havia diferenças significativas entre a Manifesto e outras empresas fora do Brasil:

Nós conseguimos ver que o que é produzido lá fora não é muito diferente do conhecimento que nós temos aqui no Brasil. As pessoas ficam com a visão de que lá fora eles sabem fazer as coisas, e não conseguem ver que não existe muita diferença. O processo de produção é o mesmo, o conhecimento e como eles produzem é tudo muito parecido! Nós nos sentimos muito mais integrados com o resto do mundo depois de todas essas investidas lá fora. Não só nós, da equipe comercial, mas toda a equipe ficou muito mais confortável. [...] Temos recebido elogios da Disney e da Zynga por nosso trabalho. Nós vemos que no Brasil estamos trabalhando e produzindo em um nível alto, no nível dos melhores do mundo. Isso nos deixa bem mais confortáveis com relação ao futuro da empresa. Vemos que não estamos longe do que está sendo feito [no exterior]. Que, independentemente das oportunidades do mercado, que está se mostrando cada vez mais promissor, temos condições idênticas para adentrar e ter sucesso em qualquer área de negócios e de produção.

\subsection{3.}

\section{Características do processo de internacionalização}

Para analisar as características do processo de internacionalização da Manifesto é preciso falar separadamente dos dois principais segmentos de atuação internacional: downloadable games e outsourcing.

\subsubsection{1. \\ Downloadable games}

A comercialização de downloadable games era sempre realizada por meio de parceiros (portais de jogos eletrônicos). A Manifesto arcava com todos os investimentos de produção, e somente após a finalização do jogo buscava parceiros para a comercialização do produto. Segundo Vieira Filho, na comercialização dos jogos sempre coube à Manifesto tomar as iniciativas para a criação de parcerias.

Vieira Filho destacou que a Manifesto obteve e continuava a obter importantes benefícios das parcerias firmadas no exterior. Em primeiro lugar, as parcerias permitiam alcançar mercados que não seriam acessáveis sem a utilização de portais de jogos eletrônicos. Por exemplo, por meio do portal Big Fish, a Manifesto já havia ultrapassado a marca de um bilhão de jogos "baixados". Outro benefício era a possibilidade de testar os jogos produzidos pela Manifesto antes do lançamento. Por exemplo, a Big Fish Games distribuía 
os jogos em versão de teste (versão beta) para mais de cinco mil jogadores de sua base de dados, usuários do portal, que se dispunham a testar jogos e, posteriormente, realizar análises e avaliações dos produtos. Essa era, então, uma oportunidade única de testar jogos para verificar possíveis falhas e também obter avaliações vindas diretamente do público-alvo, antes mesmo do lançamento oficial do jogo.

Os portais de jogos eletrônicos também prestam serviços de divulgação dos jogos de seus parceiros, pois como têm uma quantidade de acessos muito grande de usuários, todo jogo, quando é lançado em um portal, fica exposto na página principal em lugar de destaque por alguns dias. Essa divulgação pode fazer com que o desenvolvedor obtenha muitos downloads e análises (reviews) positivas ou negativas dos usuários. Nesses portais também existem listas de classificação (rankings) dos melhores jogos, que são avaliados por vários critérios, tais como: quantidade de downloads e quantidade de reviews positivas. Assim, os primeiros dias de lançamento de um jogo em um portal são de extrema importância para seu sucesso. O jogo poderá continuar na página principal, em uma sessão relacionada a "melhores jogos" do portal, enquanto obtiver uma boa colocação no ranking. Segundo Vieira Filho:

Essas parcerias não servem apenas para distribuir os jogos pelo mundo, elas servem também como uma das principais formas de promoção dos jogos, além de poder contribuir fortemente na fase de testes dos jogos. [...] Então, esse é um modelo de produto e não existe outra forma de fazer, a não ser que você próprio vá investir na promoção, lançamento e distribuição do jogo. E para fazer isso, você precisa, na verdade, além do investimento em produção, de um investimento ainda maior para promoção do jogo. São coisas bastante diferentes, então nós decidimos focar exclusivamente na produção e trabalhar com diferentes parceiros para o lançamento dos nossos jogos.

Em contrapartida, a Manifesto buscava desenvolver conteúdos inovadores, para serem distribuídos nos portais parceiros, ou seja, estava sempre buscando novas ideias para o desenvolvimento de jogos, não estando interessada em replicar produtos de sucesso no mercado.

A empresa observava e estudava continuamente o mercado mundial de jogos eletrônicos, com vistas a identificar os setores dentro da indústria de jogos eletrônicos de melhor desempenho nos últimos anos e os setores que obtinham as melhores projeções. A identificação de tendências em plataformas vigentes de jogos e em novas gerações podia significar grandes oportunidades. 


\subsubsection{2.}

\section{Outsourcing}

O foco da Manifesto em outsourcing encontrava-se na América do Norte, com maior concentração nos Estados Unidos. Os principais concorrentes eram empresas da Índia, da China, e de países do Leste Europeu, cuja vantagem competitiva em relação às empresas brasileiras em geral se encontrava em aliar competência técnica a baixo custo, esse último diretamente associado a menores impostos e a uma força de trabalho mais barata.

Para Vieira Filho, o outsourcing se ajustava muito bem às necessidades de alguns de seus clientes no principal mercado internacional da empresa:

A segunda área em que atuamos é outsourcing. Basicamente essa é a área que trabalha com exportação. Usamos a nossa expertise em jogos para produzir jogos para terceiros. Então a gente se posiciona nessa área como um parceiro, sendo parte da equipe de desenvolvimento dos nossos clientes. É uma alternativa eficiente, econômica, rápida e de extrema qualidade para empresas como MightyPlay, como Zynga, nos Estados Unidos.

A prospecção de novos clientes para o negócio de outsourcing era feita principalmente por meio de participação em feiras e eventos no exterior:

Nós temos a equipe visitando diferentes regiões, feiras e eventos ao redor do mundo para prospectar clientes, fazer contatos, apresentar nossos serviços $e$ angariar projetos para a Manifesto.

$\mathrm{Na}$ área de outsourcing a empresa buscava mais do que apenas parceiros esporádicos: o objetivo da Manifesto era estabelecer parcerias duradouras, em que a empresa passasse a ser parte do time de desenvolvimento dos seus clientes:

O processo de venda é muito caro. É difícil fechar uma venda com um novo cliente. Então, a empresa tem que focar no estabelecimento de uma relação bem mais duradoura. Nossa ideia é estabelecer relacionamentos que tragam novos contratos com o passar do tempo. O custo de pós-venda é muito mais baixo do que o custo de aquisição de um novo cliente.

Para estabelecer uma relação mais forte com seus clientes, a Manifesto buscava realmente se posicionar como parte do time, estabelecendo contato constante,passando novidades sobre novas demandas, buscando criar um relacionamento pós-venda. Dessa forma, a empresa conseguia estabelecer relações mais duradouras, não caracterizando apenas trabalhos eventuais.

No outsourcing, o maior benefício que a Manifesto proporcionava a seus clientes e parceiros era a competência (expertise), mesmo que à distância. Para superar a questão da distância física, a empresa fazia contato com seus clientes 
por meio de uso contínuo do Skypexvii, de modo a permitir que os clientes pudessem acompanhar o desenvolvimento da produção da Manifesto para ter certeza de que tudo estava sendo feito dentro das metas de qualidade e tempo previamente estabelecidas.

Segundo Vieira Filho, a empresa tinha mais dificuldades em conseguir parcerias de outsourcing na Europa, principalmente no Leste Europeu, pois as indústrias de jogos eletrônicos de países dessa região eram muito fortes no desenvolvimento de outsourcing games e também tinham um custo de produção muito próximo do custo no Brasil. O mercado europeu de outsourcing, em função disso, era menos atraente para a Manifesto.

A maior demanda do mercado internacional atendida pela Manifesto era a de outsourcing para desenvolvimento de downloadable games, tanto para dispositivos móveis, como para Facebook. Em 2013, o principal cliente da Manifesto na área de outsourcing era a Mighty Play, que prestava serviços para diversas empresas nos Estados Unidos. Foi por meio dessa empresa que a Manifesto conseguiu conquistar clientes diretos naquele país, como Disney e Sea World.

Todos os serviços eram desenvolvidos com base em contratos formais com parceiros e clientes. Nos contratos eram claramente definidos todos os termos que explicitavam direitos e deveres das partes (contratada e contratante), além dos cronogramas de desembolsos e os calendários de execução dos projetos.

\subsubsection{3.}

\section{Receita (monetização)}

A empresa faturava no mercado internacional de duas formas: royalties share e serviços. No passado, a empresa experimentou vários outros modelos de monetização, mas acabou por fixar-se nesses dois.

Na modalidade royalties share, a empresa recebia uma porcentagem sobre as vendas de seus downloadable games, sob a forma de royalties. O processo de precificação dos downloadable games era totalmente feito pelos portais de jogos eletrônicos parceiros da Manifesto. Normalmente esse preços ficavam na faixa de 6,99 a 15 dólares, de acordo com a versão do jogo, standard ou 
premium, podendo também variar de um portal para outro. Tulio Caraciolo explicou em uma entrevista à imprensa:

"Não faturamos por conta do produto, mas sim pelos valores pagos pelos consumidores para baixá-lo. [...] A receita é dividida entre os desenvolvedores e os distribuidores. Se o jogo ganha popularidade, todos ganham, se o público não gosta, a desenvolvedora amarga o prejuízo."xviii

Já na prestação de serviços, os negócios eram fechados nos formatos convencionais para a realização de um serviço, em valores fixos previamente acordados. Os preços dos serviços de outsourcing eram fixados com base nos custos, nos esforços envolvidos e no escopo do projeto.

\subsection{4.}

\section{Barreiras à internacionalização}

Um problema que preocupava os dirigentes da Manifesto Games, característico do setor de atuação da empresa, era a falta de informação sobre o mercado e, particularmente, sobre os usuários finais de seus produtos.

Quando a Manifesto começou suas atividades, produzindo browser games, a empresa tinha poucas relações com seus parceiros e com os usuários finais dos seus jogos e, por isso, recebia pouco retorno relacionado ao nível de satisfação de parceiros e clientes. Com a passagem da produção de browser games para downloadable games, a Manifesto sentiu a necessidade de estabelecer relacionamentos mais diretos com seus parceiros, e para isso os dirigentes da empresa passaram a fazer visitas a seus escritórios, com o objetivo de obter e transmitir mais confiança e, como resultado, fechar mais contratos de distribuição e obter maior feedback.

Porém, a comercialização dos downloadable games por meio de portais parceiros ainda apresentava alguns problemas referentes à falta de informações sobre os usuários dos jogos eletrônicos da empresa. A Manifesto recebia apenas relatórios referentes às vendas, ou downloads dos seus jogos, ou seja, ela não recebia informações relativas aos usuários, tais como a forma como os usuários jogavam, onde jogavam, os horários mais utilizados para jogar etc. Para Vieira Filho, tais informações seriam essenciais para uma estratégia de atuação mais eficiente.

Com relação a pesquisa de mercado no exterior, a direção da Manifesto estava sempre buscando informações recentes sobre os principais mercados no 
mundo. Vieira Filho observou, no entanto, haver farta quantidade de informações, de fácil acesso, sobre o mercado de jogos eletrônicos na América do Norte e na Europa:

Os Estados Unidos fazem pesquisa de tudo. Tudo mesmo. De consumo, como o consumidor se comporta, como os pais se relacionam com os filhos em relação a games etc.

As informações mais difíceis de serem encontradas seriam as referentes ao mercado latino-americano, que, no entanto, poderiam ser muito úteis para identificar oportunidades de negócio no Brasil e em outros países da região.

Além da falta de informação, a Manifesto precisava lidar com diversos problemas na comercialização de seus produtos e serviços no exterior, que variavam desde a falta de evolução das parcerias internacionais até questões relativas à tributação.

Um problema na parceria com os portais de jogos eletrônicos que comercializavam os jogos da Manifesto, evidenciado por Vieira Filho, era a percepção de a política de parceria não evoluir, ou seja, uma parceria feita com uma nova empresa recebia o mesmo tratamento de parcerias já estabelecidas há anos, não havendo qualquer diferenciação.

Outra barreira para a expansão das vendas internacionais - percebida como o problema mais grave enfrentado pela empresa na exportação de seus produtos - eram: os altos tributos cobrados, principalmente quando os jogos eram exportados para os Estados Unidos, principal mercado externo da Manifesto e também o maior do mundo. Para a exportação de jogos na forma de produto, os impostos pagos aos Estados Unidos, mais os impostos pagos no Brasil, inviabilizavam a maior parte dos negócios e, consequentemente, reduziam em muito a possibilidade de expansão dos negócios nesse país, pois as margens de lucro ficavam pouco atraentes.

Pelo acordo de tributação bilateral existente entre Brasil e Estados Unidos, $30 \%$ dos royalties que as empresas de jogos eletrônicos brasileiras ganhavam com vendas nos Estados Unidos eram retidos pelo governo americano. Como a divisão de receita entre a Manifesto e os portais de jogos eletrônicos era da ordem de $50 \%$ a $60 \%$ para os portais e $50 \%$ a $40 \%$ para a Manifesto, após essa divisão, $30 \%$ dos royalties da Manifesto eram retidos pelo governo americano a título de taxação, chegando apenas $28 \%$ do valor da receita dos jogos ao Brasil. Em seguida, a Manifesto pagava no mínimo 4,88\% de impostos sobre o montante recebido, podendo variar de acordo com a forma de declaração do 
lucro. Ao final, dos $100 \%$ da receita de vendas dos jogos nos Estados Unidos, a Manifesto recebia, na melhor das hipóteses, 23,12\%.

Vieira Filho sugeriu que o governo brasileiro fizesse um acordo bilateral com os Estados Unidos, para tornar o mercado americano mais atraente para a indústria de jogos eletrônicos nacional, pois as empresas exportadoras de jogos acabavam sendo abusivamente tributadas e perdiam competitividade. Ele destacou, ainda, que empresas de outros países tinham acordos de tributação bilateral melhores, tendo que pagar bem menos do que os $30 \%$ recolhidos pelas empresas brasileiras nos Estados Unidos.

Com relação ao negócio de outsourcing, para Vieira Filho o principal problema era o custo de produção no Brasil devido à alta carga tributária e às contribuições trabalhistas, que, em muitos casos, podiam ultrapassar $100 \%$ do valor do salário. Os tributos geravam custos muito altos e, como consequência, tornavam a indústria brasileira de jogos eletrônicos menos competitiva do que a de outros países, como os do Leste Europeu, China e Índia.

Outro problema evidenciado por Vieira Filho era a desconfiança - até mesmo o preconceito - por parte de parceiros internacionais, com relação à capacidade técnica e ao profissionalismo de empresas dejogos eletrônicosda América Latina em geral:

Muitos clientes com quem entramos em contato, já trabalharam com empresas chilenas ou argentinas. Acho que nenhum havia trabalhado com empresas brasileiras, mas em todos os casos eles diziam que não tinham tido uma boa experiência. Ou o prazo estourava, ou a entrega não era feita, ou o developer queria mais dinheiro porque o estúdio não conseguia terminar etc.

Para superar essa barreira, a direção da Manifesto percebeu que conseguiria maior receptividade dos parceiros por meio de reuniões presenciais, e não somente pela internet. Para Vieira Filho, haveria a necessidade de presença física constante fora do Brasil, principalmente nos Estados Unidos, por meio de uma pessoa ou de um escritório. Mas como isso ainda não era viável para a Manifesto, tentava-se preencher essa lacuna por meio de participação em feiras e eventos nos Estados Unidos, prospectando e promovendo a empresa. 


\subsection{5. \\ Facilitadores para a internacionalização}

A Manifesto já participou de ações com Apex e Softex. Nos anos de 2012 e 2013, a empresa foi beneficiada por uma iniciativa conjunta da Apex e da Softex para promover as exportações. Nessa iniciativa, as instituições custeavam parte das despesas de participação na feira Game Developers, em San Francisco, nos Estados Unidos, sendo os custos relativos ao espaço na feira e à montagem dos estandes pagos pela iniciativa, enquanto os custos com passagem e hospedagem eram absorvidos pelas próprias empresas, como contrapartida. Segundo Vieira Filho, esse incentivo para a participação em feiras internacionais foi muito produtivo, e tais iniciativas deveriam se intensificar.

A empresa pretendia aumentar sua participação em feiras internacionais, de duas para três por ano, tanto com o propósito de promover seus produtos e serviços, como de estabelecer agentes na Inglaterra e nos Estados Unidos para representarem a empresa. Na Inglaterra já estava em curso a primeira tentativa e nos Estados Unidos a empresa estava buscando um representante. A Manifesto utilizava também redes sociais, como Linkedin, para a prospecção, a divulgação do seu site e a ampliação de sua network.

A grande maioria dos projetos realizados pela Manifesto foi iniciada a partir dos esforços diretos da empresa na busca por clientes e parceiros, ou seja, foram poucos os casos em que a Manifesto foi procurada por um cliente. No entanto, a direção da Manifesto pretendia alterar em parte esse quadro, investindo mais em propaganda ao invés de buscar clientes e parceiros. O objetivo final era tornar a marca Manifesto cada vez mais conhecida por meio da mídia e da participação em eventos, e desse modo, fazer com que a empresa passasse a ser mais procurada por futuros clientes e parceiros.

Uma das sugestões de Vieira Filho para aprimorar o suporte dado por instituições como Sebrae, Apex e Softex a pequenas empresas brasileiras que desejam começar a exportar ou se internacionalizar foi a disponibilização de consultoria tributária, para ajudar os empresários a entenderem melhor o funcionamento do sistema e adotarem formas de minimizar os efeitos da tributação em suas atividades internacionais. A Manifesto Game Studio teve que recorrer a uma consultoria tributária privada para desenvolver um modelo de tributação para atuar no exterior. Esse planejamento tributário levou meses para ficar pronto e gerou custos financeiros diretos, como o pagamento da 
consultoria, e também custos indiretos, pois a empresa passou vários meses sofrendo bitributação (tributos pagos nos Estados Unidos e no Brasil).

Para Vieira Filho, um ponto importante para possibilitar o crescimento da indústria nacional de jogos eletrônicos seria, primeiramente, a criação de condições para empresas brasileiras ganharem mais força internamente, já que no Brasil existem muitos entraves para a exportação e internacionalização de suas empresas:

Dados todos os entraves que temos aqui no Brasil para exportar e a dificuldade que temos para estar nos principais mercados, um ponto importante seria criar condições, aqui no Brasil, para as empresas ganharem mais força, para, só então, partirem para fora com muito mais condições de dar certo. E aí, talvez, vá depender menos de iniciativas como essas - parceiros, eventos e tudo mais.

Em sua opinião, determinadas iniciativas governamentais poderiam fortalecer a indústria brasileira de jogos eletrônicos. O governo brasileiro poderia tomar medidas semelhantes às do governo russo, que possibilitou acentuado crescimento da indústria de jogos eletrônicos naquele país. Entre as diversas medidas de incentivo à indústria local, o governo determinou que $10 \%$ dos jogos oferecidos no país deveriam vir da indústria russa de jogos eletrônicos. Vieira Filho admitiu que esse modelo poderia ser extremo para o Brasil, mas que servia para exemplificar como algumas medidas tomadas pelo governo poderiam gerar resultados muito positivos. Como resultado das iniciativas adotadas pelo governo russo, um desenvolvedor russo - com quem a Manifesto tinha parceria - liderava o mercado de downloadable games daquele país e era uma empresa expressiva no mercado mundial. Essa empresa russa cresceu explorando o mercado interno, com o apoio do governo e, somente depois de atingir certo tamanho e experiência, partiu para a internacionalização.

As empresas de jogos eletrônicos de países latino-americanos, normalmente, têm maior dificuldade em conquistar novos clientes internacionais para o desenvolvimento de serviços, pois tais clientes, em geral, duvidariam da capacidade técnica e do profissionalismo dessas empresas. Para contornar essa dificuldade, a Manifesto buscou construir um histórico de serviços internacionais prestados e intensificou esforços para entregar seus projetos dentro do prazo acordado com seus clientes.

Hoje, o principal ponto, na verdade, é a qualidade da empresa, que é verificada pelo nosso histórico de expertise de mais de oito anos de produção de jogos e mais de 100 jogos produzidos para as grandes plataformas. Outro ponto é a questão do profissionalismo: nós entregamos nossos produtos e projetos dentro do prazo. 
Segundo Vieira Filho, a Manifesto também havia construído outro grande diferencial em relação a seus principais concorrentes internacionais (do Leste Europeu, China e Índia): localização. O Brasil está mais próximo da América do Norte e de parte da Europa (comparativamente com China e Índia). Para realizar serviços de outsourcing, é necessário que as empresas mantenham contato frequente durante a produção dos jogos, tornando a proximidade de fuso horário muito importante. Por exemplo, a diferença de fuso horário entre Recife e San Francisco, nos Estados Unidos, é de apenas quatro horas (podendo mudar um pouco de acordo com os respectivos horários de verão). Em função da pequena diferença, era possível à Manifesto manter contato em tempo real com os clientes localizados naquela cidade. Já as empresas chinesas e indianas têm mais dificuldade de comunicação, uma vez que as diferenças de fuso horário são de 10 a 12 horas. Desta forma, grandes diferenças de fuso horário também podem dificultar a construção de um relacionamento de confiança com o cliente, pois tornam mais difícil acompanhar o andamento de projetos contratados. 


\section{Análise dos casos}

Nesta seção,o objetivo foi criar conclusões a partir da análise cruzada dos casos estudados, e prover análises detalhadas de cada um dos casos. O foco aqui é identificar pontos em comum e diferenças nos processos de internacionalização das duas empresas, e para isso são mostrados os resultados da análise qualitativa dos dados, que buscou explicar as perguntas feitas neste estudo que formam a base para o entendimento do processo de internacionalização de empresas brasileiras de jogos eletrônicos, e como elas conseguem se tornar sustentáveis no mercado global de jogos.

\section{1.}

Determinantes do processo de internacionalização

\begin{tabular}{|c|c|}
\hline \multicolumn{2}{|l|}{ Aquiris } \\
\hline $\begin{array}{l}\text { Mercado } \\
\text { brasileiro de } \\
\text { jogos eletrônicos } \\
\text { pouco } \\
\text { desenvolvido, e } \\
\text { facilidades } \\
\text { existentes para } \\
\text { exportar }\end{array}$ & $\begin{array}{l}\text { Hoje em dia, não tem porque lançar um game só no Brasil. Com } \\
\text { as plataformas digitais o mundo todo está ao nosso alcance muito } \\
\text { mais facilmente do que em quando os games estavam restritos a } \\
\text { consoles, ou a jogos de caixinha, que tinham distribuição física. } \\
\text { Com o mundo digital e as plataformas digitais, não temos porque } \\
\text { nos limitar a um mercado geográfico único. Então, fazer parte } \\
\text { dessa network internacional é extremamente natural e } \\
\text { necessário... se uma empresa de games quer crescer, ela não } \\
\text { tem como ficar restrita ao mercado nacional. }\end{array}$ \\
\hline \multicolumn{2}{|l|}{ Manifesto } \\
\hline $\begin{array}{l}\text { Mercado } \\
\text { brasileiro de } \\
\text { jogos eletrônicos } \\
\text { pouco } \\
\text { desenvolvido }\end{array}$ & $\begin{array}{l}\text { Realizando programas estratégicos da Manifesto, nós } \\
\text { identificamos que o Brasil voltou a ter muita, não voltou, ele } \\
\text { começou a ter maiores oportunidades também na indústria dos } \\
\text { jogos. Então, lá em } 2005 \text { quando a gente fundou a empresa } \\
\text { essas oportunidades eram áreas muito escassas. }\end{array}$ \\
\hline
\end{tabular}

Primeiramente, é importante evidenciar que o surgimento das empresas estudadas e a atuação delas no mercado internacional só foram possíveis devido aos avanços tecnológicos e de comunicação. Foi com o surgimento da internet que empresas de jogos eletrônicos passaram a poder distribuir jogos diretamente para seus consumidores finais sem a necessidade do varejo. Os 
avanços nos meios de comunicação tornaram possível a atuação das empresas estudadas neste trabalho na prestação de serviços de outsourcing e na coprodução de jogos eletrônicos com empresas de diversas regiões do planeta, possibilitando que essas empresas se comuniquem diariamente, em tempo real, e pelo tempo que for necessário com seus clientes e parceiros, e com um custo muito baixo.

As alterações nos modelos de negócios da indústria de jogos eletrônicos foram também responsáveis pela entrada de pequenas empresas, como a Aquiris e a Manifesto, na indústria nacional e internacional, pois os jogos eletrônicos, que antes eram apenas desenvolvidos por grandes empresas, atualmente já são desenvolvidos por diversas empresas de pequeno porte em todo o planeta e para qualquer tipo de dispositivo, seja ele um console de jogos eletrônicos de última geração ou dispositivos mais simples que foram criados para outros propósitos, como telefones celulares.

A Aquiris e a Manifesto tiveram que lidar com fatores ambientais do mercado brasileiro, pois esse mercado se encontrava e ainda se encontra pouco desenvolvido, em que a pirataria de jogos é comum e os impostos cobrados aos consumidores finais fazem com que os jogos eletrônicos custem no Brasil mais do dobro que nos Estados Unidos. Para lidar com esse problema as duas empresas adotaram as mesmas estratégias: buscaram exportar seus jogos para mercados internacionais mais desenvolvidos, e passaram a desenvolver serious games para o mercado brasileiro, que são menos suscetíveis a pirataria.

A Manifesto logo na sua fundação buscava o mercado internacional.Esse foco no exterior pode ser visto como uma forma de buscar alternativas à baixa atratividade do mercado brasileiro, mas também ao fato da empresa ter sido criada dentro de um ambiente institucional de apoio ao empreendedorismo desde o início de suas atividades, que pode ter contribuído para uma visão internacional do seu negócio. Em que o suporte recebido inicialmente pelos jovens empreendedores, particularmente nos ambientes protegidos e estimulantes da UFPE, da pré-incubadora e do C.E.S.A.R. despertaram os fundadores da empresa para o potencial de empreender e moldaram uma visão voltada para o mercado internacional. 
A Aquiris buscou também o mercado internacional não somente pelas condições ruins do seu mercado doméstico, mas também por perceber as facilidades existentes para atuar no mercado internacional por meio de parcerias com publishers, em que poderia atuar em diversos outros mercados maiores e mais desenvolvidos que o brasileiro sem ter que desenvolver habilidades e estruturas para distribuir e divulgar seus produtos.

\section{2.}

\section{Escolhas dos países}

\begin{tabular}{|c|c|}
\hline \multicolumn{2}{|l|}{ Aquiris } \\
\hline $\begin{array}{lr}\text { Estados } & \text { Unidos } \\
\text { como } & \text { centro } \\
\text { mundial de } & \text { jogos } \\
\text { eletrônicos } & \text { para } \\
\text { negócios. } & \end{array}$ & $\begin{array}{l}\text { O nosso mercado base é sempre o norte-americano. Usamos os } \\
\text { Estados Unidos como ponte para qualquer outro mercado, por } \\
\text { enquanto. Toda a indústria de games que ainda podemos } \\
\text { explorar - fora a China, que é um mercado particular - podemos } \\
\text { alcançar via o mercado americano. }\end{array}$ \\
\hline $\begin{array}{l}\text { Busca por outros } \\
\text { mercados via EUA. } \\
\text { Falta de recursos } \\
\text { para atuar } \\
\text { diretamente em } \\
\text { outros mercados. }\end{array}$ & $\begin{array}{l}\text { Há uma feira no Japão. Gostaríamos de ir? Sim, gostaríamos. } \\
\text { Talvez gerasse negócios diretos lá? Talvez. Mas são viagens } \\
\text { ainda mais caras, que têm que competir com as viagens que a } \\
\text { gente já faz para os Estados Unidos. Então, se temos que } \\
\text { escolher um lugar, se não podemos ir para todos [os lugares], } \\
\text { conseguimos atingir esses outros mercados via Estados Unidos. }\end{array}$ \\
\hline \multicolumn{2}{|l|}{ Manifesto } \\
\hline $\begin{array}{l}\text { Busca de parcerias } \\
\text { para aumentar } 0 \\
\text { alcance na } \\
\text { distribuição dos } \\
\text { jogos }\end{array}$ & $\begin{array}{l}\text {...então quando a gente começa a produzir e a entrar em um } \\
\text { estágio mais avançado de produção, a gente iniciou com } \\
\text { diferentes parceiros de distribuição para a gente colocar os } \\
\text { nossos jogos a frente da maior quantidade de jogadores. }\end{array}$ \\
\hline $\begin{array}{l}\text { A empresa já } \\
\text { nasceu com a } \\
\text { intenção de atuar } \\
\text { internacionalmente. }\end{array}$ & $\begin{array}{l}\text { A Manifesto sempre teve um pé muito mais no exterior do que } \\
\text { no Brasil. Hoje em dia é que nós estamos modificando um } \\
\text { pouco esse cenário... Mas a Manifesto, em 2005, já nasceu com } \\
\text { a visão de atuar no mercado internacional. Em diferentes } \\
\text { regiões do mundo, diferentes idiomas... É uma experiência muito } \\
\text { gratificante. }\end{array}$ \\
\hline
\end{tabular}

As duas empresas buscam distribuir seus jogos em diversas regiões do mundo, porém como a distribuição dos jogos é feita por seus parceiros, as empresas na realidade focam no trabalho de buscar mais parcerias com publishers para aumentar ao máximo o alcance na distribuição dos seus jogos. No caso da Manifesto Games, a empresa atua de duas formas, a primeira é exportando jogos por meio de publishers, neste caso é possível verificar que a empresa começou com o foco maior em mercados de países ocidental, e 
posteriormente passou a atuar também no mercado asiático, pois conseguiu estabelecer novas parcerias que atuavam com mais intensidade nessas regiões. A segunda forma de atuação é por meio da prestação de serviços de outsourcing, neste caso a empresa tinha o foco voltado para o mercado norte americano, pois além de ser o maior mercado de jogos eletrônicos do mundo, trazia um diferencial competitivo para empresas localizadas na América do Sul, pois os serviços de outsourcing em jogos eletrônicos necessitam de um acompanhamento da produção intenso do lado da terceirizada e do lado do cliente, em que é necessária uma troca constante de informações durante todo o processo de produção. Como a diferença de fuso horário de empresas localizadas nos Estados Unidos e no Brasil é pequena, clientes norte americanos poderiam acompanhar o processo de produção dos jogos encomendados com maior facilidade do que em países como a China, Índia, e países do Leste Europeu que possuem uma diferença de fuso horário com os EUA de até doze horas.

Já a Aquiris Games sempre buscou novos clientes e parceiros nos Estados Unidos, pois é nesse mercado que se encontram a maioria das grandes empresas de jogos eletrônicos no mundo. O mercado americano é o maior do mundo, e acaba funcionando como um grande centro mundial de empresas de jogos eletrônicos, assim embora a Aquiris e a Manifesto foquem mais em conseguir clientes nos Estados Unidos, devido à diversidade de nacionalidades de empresas que fazem negócios nos EUA, as duas acabam realizando negócios com empresas de outros países também.

\section{3.}

\section{Barreiras e obstáculos dos processos de internacionalização}

\begin{tabular}{|l|l|}
\hline \multicolumn{2}{|l|}{ Aquiris } \\
\hline $\begin{array}{l}\text { Problema no } \\
\text { cumprimento de } \\
\text { um contrato }\end{array}$ & $\begin{array}{l}\text { É convite para um pouquinho mais longa... A empresa que nos fez } \\
\text { o projeto. Ela tinha oferecido muito poucos recursos para a } \\
\text { assinado. }\end{array}$ \\
$\begin{array}{l}\text { Aquiris fazer o projeto. Nós tínhamos aceitado, mas nos demos } \\
\text { conta de que era impossível. Voltamos a eles para negociar mais } \\
\text { verba, mas eles já não tinham isso como prioridade. }\end{array}$ \\
\hline
\end{tabular}




\begin{tabular}{|c|c|}
\hline $\begin{array}{lr}\text { Desvantagem } & \text { na } \\
\text { negociação } & \text { de } \\
\text { contratos } & \text { com } \\
\text { grandes } & \\
\text { publishers }\end{array}$ & $\begin{array}{l}\text { Para negociar com players internacionais, o ideal é ter saúde } \\
\text { financeira, boa o suficiente para poder exigir um pouco mais dos } \\
\text { contratos. Porque se a empresa não tem essa saúde financeira, } \\
\text { acaba fechando contratos que não são os mais justos. [...] Temos } \\
\text { a clara percepção de que, enquanto a indústria brasileira não for } \\
\text { grande o suficiente, não tiver fôlego suficiente, vai fazer contratos } \\
\text { não muito bons. Isso vai acontecer a menos que se tenha mais } \\
\text { fôlego para negociar um pouco mais de justiça com um mercado } \\
\text { que é muito maior. }\end{array}$ \\
\hline $\begin{array}{l}\text { Alto custo de } \\
\text { produção devido } \\
\text { aos } \quad \text { altos } \\
\text { impostos. }\end{array}$ & $\begin{array}{l}\text { O custo da Aquiris não é baixo, então, quando estamos } \\
\text { negociando um contrato fora do Brasil, há ainda a dificuldade da } \\
\text { distância, e essa distância, não sendo ajudada por um custo muito } \\
\text { mais baixo, torna ainda mais difícil para o parceiro de fora nos } \\
\text { contratar ou nos ter como parceiro ideal. }\end{array}$ \\
\hline $\begin{array}{lr}\text { Contratação } & \text { de } \\
\text { consultoria } & \text { para } \\
\text { criação } & \text { de } \\
\text { contrato. } & \end{array}$ & $\begin{array}{l}\text { É muito caro para uma empresa sozinha bancar. Nós, por } \\
\text { exemplo, investimos } 40 \text { mil reais numa consultoria jurídica para } \\
\text { fazer o contrato com a Rumble. [...] É por falta de experiência com } \\
\text { contratos internacionais, que todo mundo acaba aceitando o que } \\
\text { vem, porque não tem condições de contratar uma consultoria para } \\
\text { que essa consultoria diga: "olha, essa cláusula aqui, ela vai te } \\
\text { trazer essa, essa e essa consequência", entende? [...] Então, são } \\
\text { coisas que matam a indústria, ainda no começo. Fazendo maus } \\
\text { contratos, acaba morrendo ainda mais cedo. }\end{array}$ \\
\hline \multicolumn{2}{|l|}{ Manifesto } \\
\hline $\begin{array}{l}\text { Necessidade de } \\
\text { consultoria } \\
\text { tributária }\end{array}$ & $\begin{array}{l}\text {...nós tivemos que recorrer a consultoria tributária, foi um } \\
\text { processo de longos meses para conseguir entender toda essa } \\
\text { taxação e tentar identificar um modelo para minimizar os efeitos } \\
\text { dessa tributação. }\end{array}$ \\
\hline $\begin{array}{l}\text { Alto custo de } \\
\text { produção devido } \\
\text { aos } \\
\text { impostos. }\end{array}$ & $\begin{array}{l}\text {...estúdios e mais estúdios que montaram em Brasília, em São } \\
\text { Paulo, sofrendo com a carga tributária [...] É estranho para todos } \\
\text { eles e para nós também isso é bastante complexo, nos deixa } \\
\text { menos competitivos. Você pagar (uma parte) do seu salário, do } \\
\text { seu honorário. Você pagar } 70 \text {, muitas vezes mais de } 100 \% \text { de } \\
\text { carga tributária sobre o salário do funcionário. }\end{array}$ \\
\hline $\begin{array}{ll}\text { Preconceito } & \text { com } \\
\text { empresas } & \text { sul- } \\
\text { americanas. } & \end{array}$ & $\begin{array}{l}\text { Muitos clientes com quem entramos em contato, já trabalharam } \\
\text { com empresas chilenas ou argentinas. Acho que nenhum havia } \\
\text { trabalhado com empresas brasileiras, mas em todos os casos eles } \\
\text { diziam que não tinham tido uma boa experiência. Ou o prazo } \\
\text { estourava, ou a entrega não era feita, ou o developer queria mais } \\
\text { dinheiro porque o estúdio não conseguia terminar etc. }\end{array}$ \\
\hline $\begin{array}{l}\text { Falta de } \\
\text { informações } \\
\text { sobre os usuários } \\
\text { dos jogos. }\end{array}$ & $\begin{array}{l}\text { Nós tínhamos pouca informação sobre como é que o usuário joga, } \\
\text { onde ele joga, em que horário ele entra mais, nós tínhamos [...] } \\
\text { Muito mais relatório de vendas do que relatório de consumo. } \\
\text { Então isso ainda complica bastante. É difícil você criar uma } \\
\text { estratégia para o público que você vai atuar, que jogos você vai } \\
\text { criar se você conhece um pouco ainda do seu usuário. }\end{array}$ \\
\hline
\end{tabular}


Despesas eventuais podem trazer sérios problemas para pequenas empresas, com poucos recursos e pouca experiência internacional. Essas empresas tem dificuldade em planejar seu processo de internacionalização devido à falta de conhecimento e ao mesmo tempo não possui recursos para gastos eventuais, assim, no início do processo de internacionalização essas empresas estão altamente dispostas a correr riscos, porém ao longo do processo, conforme elas vão ganhando experiência, a disposição para correr riscos vai diminuindo. A Aquiris com o passar do tempo foi criando mais consciência das limitações, e consequentemente passou a ter mais cautela na aceitação e criação de projetos, em que muitas vezes optava por projetos menos lucrativos, porém com menor risco. Já a Manifesto, desde o início já apresentava maior cautela em sua atuação internacional. Porém, alguns problemas enfrentados pelas duas empresas evidenciaram a fragilidade delas. No caso da Manifesto a empresa sentiu a necessidade de contratar uma consultoria tributária, pois a empresa estava pagando taxas além do necessário, e que tornavam seus projetos menos rentáveis e em alguns casos até mesmo inviáveis. No caso da Aquiris a empresa sentiu a necessidade de contratar um advogado para rever contratos com parceiros internacionais, pois em uma experiência anterior, a empresa assinou um contrato que acabou quase comprometendo suas finanças. Nos dois casos, as empresas tiveram que arcar com despesas (advogado, consultoria etc) eventuais que apesar de serem serviços relativamente baratos para grandes empresas, para pequenas BGs pode monerá-las significativamente.

A desconfiança de empresas internacionais na contratação de empresas Sul Americanas também foi um problema apontado no caso da Manifesto Games, em que devido à más experiências com empresas da América do Sul muitas empresas no exterior possuem certo preconceito para contratação de serviços, e que isso acabou gerando um esforço extra da Manifesto para conseguir realizar alguns negócios, como a visita de diretores a empresas Norte Americanas para tentar transmitir mais confiabilidade. No lado da Aquiris, foi possível verificar a existência de uma experiência ruim que corrobora com a má expectativa das empresas estrangeiras, em que a Aquiris, por inexperiência, assina um contrato com uma empresa internacional para o desenvolvimento de um jogo, e durante o desenvolvimento do projeto é obrigada a desistir do projeto por falta de verba.Para a Aquiris, as empresas brasileiras terão desvantagens em negociar contratos com grandes publishers, pois essas empresas não 
possuem saúde financeira suficiente para exigir contratos mais justos, e que para melhorar essa situação seria necessário o fortalecimento da indústria brasileira de jogos eletrônicos.

Outra dificuldade reportada pela Manifesto é a pouca informação sobre seus usuários finais, pois seus parceiros (publishers), que fazem a distribuição dos jogos produzidos pela Manifesto enviam apenas relatórios sobre as vendas da empresa, ou seja, não disponibilizam informação sobre os compradores dos jogos, assim a Manifesto tem dificuldade em entender seus clientes finais e consequentemente dificuldade em criar jogos mais adequados às expectativas de seus usuários. Esse problema foi colocado por Sinkovics, Sinkovics e Jean(2013) que examina o fracasso de empresas que possuem um alto comprometimento com a internacionalização online, e acabam aumentando a distância física e relacional dos mercados externos em que atua, e consequentemente passam a ter um baixo desempenho internacional. A Manifesto apesar de ter a consciência da necessidade de entender melhor seus clientes, depende de seus parceiros publishers para obter as informações sobre os usuários dos seus jogos. Como seus parceiros não fornecem tais informações, a Manifesto acaba não conseguindo atender melhor seus clientes e consequentemente se vê impossibilitada de melhorar seu desempenho com exportações de jogos via Publisher.

Dentre os problemas enfrentados pelas empresas, os impostos cobrados à indústria de jogos eletrônicos no Brasil parece ser o mais impactante. A Aquiris Games e a Manifesto Games relatam dificuldade em pagar todos os impostos cobrados. Na prestação de serviços em outsourcing no caso da Manifesto, ou em coproduções de jogos eletrônicos no caso da Aquiris, as empresas relatam que há excessiva carga tributária e contribuições trabalhistas, e que em muitos casos essas cobranças chegam a superar o valor dos salários dos seus funcionários. Devido ao excesso de impostos, essas empresas acabam perdendo diferencial competitivo, pois o custo de manutenção de um funcionário no Brasil acaba ficando próximo ao de países desenvolvidos, onde os empregados, em grande parte das vezes, contam com melhores salários e melhores condições de trabalho. Já para a exportação de jogos eletrônicos,as cargas tributárias são ainda maiores, pois além dos custos referentes aos impostos de contratação e manutenção da mão de obra, as taxas pagas para exportação de jogos são consideravelmente maiores que as pagas na prestação de serviços. No caso extremo de exportações para os Estados Unidos, que é o 
principal mercado de jogos eletrônicos do mundo, $30 \%$ dos royalties pagos às empresas brasileiras são recolhidos ainda nos EUA, e depois ainda são cobrados os impostos no Brasil. Essa dupla tributação na exportação de jogos, muitas vezes inviabiliza negócios para as empresas brasileiras.

6.4 .

Facilitadores dos processos de internacionalização

\begin{tabular}{|c|c|}
\hline \multicolumn{2}{|l|}{ Aquiris } \\
\hline $\begin{array}{l}\text { Participação em } \\
\text { feiras como } \\
\text { principal forma } \\
\text { de prospecção. }\end{array}$ & $\begin{array}{l}\text { É, de fato, a nossa oportunidade de mostrar o que a Aquiris faz, o } \\
\text { que a empresa tem de produto, de prestação de serviço. É a } \\
\text { nossa maior fonte de prospecção internacional. É claro que são } \\
\text { contatos rápidos e, portanto, temos todo o trabalho de dar } \\
\text { continuidade aos mesmos depois, a partir daqui do Brasil. Mas, } \\
\text { não estar presente nesses eventos torna inviável consolidar novos } \\
\text { negócios. }\end{array}$ \\
\hline $\begin{array}{lr}\text { Facilidade } & \text { de } \\
\text { exportar } & \text { via } \\
\text { publishers } & \end{array}$ & $\begin{array}{l}\text { Com o mundo digital e as plataformas digitais, não temos porque } \\
\text { nos limitar a um mercado geográfico único. Então, fazer parte } \\
\text { dessa network internacional é extremamente natural e } \\
\text { necessário... }\end{array}$ \\
\hline \multicolumn{2}{|l|}{ Manifesto } \\
\hline $\begin{array}{l}\text { Participação em } \\
\text { feiras como } \\
\text { principal forma } \\
\text { de prospecção. }\end{array}$ & $\begin{array}{l}\text { Talvez seja uma barreira não ter essa presença física lá fora. A } \\
\text { gente acabou substituindo um pouco dessa lacuna através da } \\
\text { participação em feiras e eventos nos Estados Unidos. }\end{array}$ \\
\hline $\begin{array}{l}\text { Diferencial em } \\
\text { atendimento de } \\
\text { clientes devido a } \\
\text { proximidade de } \\
\text { fuso-horário }\end{array}$ & $\begin{array}{l}\text {...outro ponto é a nossa localização. Nós estamos próximos, não } \\
\text { estamos tão distantes assim do fuso horário da América do Norte, } \\
\text { inclusive da Europa também [...] é um fator importante. Por } \\
\text { exemplo, na cidade mais a oeste dos Estados Unidos, são } \\
\text { Francisco a gente mais ou menos tá a } 4,5 \text { horas de distância, vai } \\
\text { depender se eles estão em horário de verão ou não. [...] sem } \\
\text { descartar o horário de expediente, nós conseguimos conversar } \\
\text { com eles normalmente. Falando em termos de Europa também, } \\
\text { talvez } 4 \text { ou } 5 \text { horas de diferença, então nós conseguimos } \\
\text { conversar. Isso já muda para as [empresas] que estão localizadas } \\
\text { na Índia e China, por exemplo. }\end{array}$ \\
\hline
\end{tabular}

A participação em feiras internacionais de jogos eletrônicos se mostrou como grande facilitador da internacionalização das empresas Aquiris e Manifesto. Como as empresas ainda não possuem instalações fora do Brasil, as feiras passaram a ser a principal forma de prospecção de clientes e parceiros. As duas empresas buscam participar de pelo menos duas feiras internacional ao ano, e contam com a ajuda da APEX para financiar parte das suas despesas com as feiras. 
Outro facilitador apontado por pelo diretor de negócios da Manifesto Games é a proximidade do Brasil com a América do Norte e parte da Europa, comparativamente com a China, Índia e Leste Europeu. Para realizar serviços de outsourcing, ou coproduções, é preciso que a empresa mantenha contato constante e durante o horário de trabalho enquanto um jogo estiver sendo produzido, assim a proximidade de fuso horário facilita muito a interação entre as empresas. No caso da Aquiris, tal facilitador não foi evidenciado, porém a empresa fatalmente também se beneficia da proximidade de fuso horário no desenvolvimento de coproduções de jogos eletrônicos. $\mathrm{Na}$ análise do setor de jogos eletrônico deste trabalho, Helyar(2012)corrobora com a ideia do diretor de negócios da Manifesto, relatando que o Brasil possui grande potencial com relação a mão de obra qualificada, em que é possível desenvolver jogos eletrônicos com custos inferiores aos dos países desenvolvidos, e que devido a proximidade de fuso horário entre América do Norte e América do Sul as empresas brasileiras acabam conseguindo ter maior interação com as empresas norte americanas na realização de serviços de outsourcing.

No caso Aquiris foi explicada as vantagens de se associar a associações brasileiras ligadas a jogos eletrônicos, que estão empenhadas em fomentar a produção e exportação brasileira de jogos. Foi evidenciado o esforço da Associação Brasileira dos Desenvolvedores de Jogos Digitais (Abragames) em conjunto com a APEX para criação de feiras internacionais, seguindo o mesmo modelo das principais feiras do setor, como a Game Connection, com o objetivo de trazer publishers e Empresas Internacionais para rodadas de negócios com empresas brasileiras. No Brasil grande parte das empresas desenvolvedoras de jogos eletrônicos ainda não tem condições de arcar com os custos para a participação de feiras internacionais em outros países, mesmo com a ajuda da APEX, assim a criação de uma feira internacional de desenvolvimento de jogos eletrônicos no Brasil pode viabilizar a entrada dessas empresas no mercado internacional.

A Manifesto também colocou a desvalorização da real em relação ao dólar como um facilitador das exportações, pois seus produtos e serviços ficaram mais valorizados. 
O diretor comercial da Aquiris evidenciou a facilidade em exportar jogos atualmente, e que essa facilidade nas exportações seus produtos e serviços foi um dos principais motivos para a empresa buscar o mercado externo. Com a criação de parcerias com grandes publishers um jogo pode ser comercializado praticamente no mundo inteiro, sem que a empresa desenvolvedora tenha que se preocupar com a distribuição e a publicidade do jogo.Assim as duas empresas parecem seguir a recomendação de Sinkovics, Sinkovics e Jean (2013) em não utilizar a internet como único meio de distribuição dos seus jogos. Para Sinkovics, Sinkovics e Jean (2013) empresas que apresentam um alto comprometimento com a internacionalização online, tendem a generalizar seus conhecimentos sobre os mercados, e assim não analisam plenamente as complexidades dos seus clientes. Porém, no caso da Manifesto foi verificada uma insatisfação com relação a pouca informação que os publishers parceiros da empresa davam sobre os consumidores dos jogos produzidos pela Manifesto, isso mostra que apesar da Manifesto utilizar grandes publishers para distribuição dos seus jogos, ainda existem problemas relacionados à falta de conhecimento dos clientes. Com relação aos serviços prestados pelas duas empresas, devido ao alto nível de interação entre as empresas envolvidas, elas não têm problemas para analisar plenamente as complexidades dos seus clientes.

\section{5 .}

\section{Sustentabilidade das empresas no mercado internacional}

\begin{tabular}{|c|c|}
\hline \multicolumn{2}{|l|}{ Aquiris } \\
\hline $\begin{array}{l}\text { Desenvolvimento } \\
\text { de parcerias com } \\
\text { coproduções. }\end{array}$ & $\begin{array}{l}\text { A Rumble é um publisher, mas também é um desenvolvedor. Eles } \\
\text { desenvolvem games internamente também, além de terceirizar } \\
\text { com a Aquiris esse desenvolvimento. Terceirizar não é bem a } \\
\text { palavra, porque nós somos sócios no projeto, mas eles não } \\
\text { desenvolvem só internamente, desenvolvem com estúdio fora, que } \\
\text { é o nosso caso. }\end{array}$ \\
\hline $\begin{array}{l}\text { Fortalecimento de } \\
\text { parcerias. }\end{array}$ & $\begin{array}{l}\text { Quando fomos nesse início de ano [2013] aos Estados Unidos, } \\
\text { fomos a Atlanta especificamente para fazer uma visita à Cartoon } \\
\text { Network. Fizemos questão de ir lá, porque tínhamos tido um caso } \\
\text { bastante bom com o jogo que desenvolvemos no segundo } \\
\text { semestre do ano passado. Então, foi muito importante colher esse } \\
\text { feedback, conhecer pessoas novas da equipe, e assim por diante. }\end{array}$ \\
\hline \multicolumn{2}{|l|}{ Manifesto } \\
\hline $\begin{array}{l}\text { Diferencial } \\
\text { competitivo } \\
\text { baseado na } \\
\text { qualidade dos } \\
\text { produtos e } \\
\text { serviços. }\end{array}$ & $\begin{array}{l}\text { Hoje, o principal ponto, na verdade, é a qualidade da empresa, que } \\
\text { é verificada pelo nosso histórico de expertise de mais de oito anos } \\
\text { de produção de jogos e mais de } 100 \text { jogos produzidos para as } \\
\text { grandes plataformas. Outro ponto é a questão do profissionalismo: } \\
\text { nós entregamos nossos produtos e projetos dentro do prazo. }\end{array}$ \\
\hline
\end{tabular}




\begin{tabular}{|l|l|}
\hline $\begin{array}{l}\text { Desenvolvimento } \\
\text { de parcerias com } \\
\text { outsourcing } \\
\text { games. }\end{array}$ & $\begin{array}{l}\text { A segunda área em que atuamos é outsourcing. Basicamente essa } \\
\text { é a jog trea para tha com exportação. Usamos a nossa expertise } \\
\text { posiciona nessa área como um parceiro, sendo parte da equipe de } \\
\text { desenvolvimento dos nossos clientes. É uma alternativa eficiente, } \\
\text { econômica, rápida e de extrema qualidade para empresas como } \\
\text { MightyPlay, como Zynga, nos Estados Unidos. }\end{array}$ \\
\hline $\begin{array}{l}\text { Fortalecimento de } \\
\text { parcerias. }\end{array}$ & $\begin{array}{l}\text { A empresa tem que focar no estabelecimento de uma relação bem } \\
\text { mais duradoura. Nossa ideia é estabelecer relacionamentos que } \\
\text { tragam novos contratos com o passar do tempo. O custo de pós- } \\
\text { venda é muito mais baixo do que o custo de aquisição de um novo } \\
\text { cliente. }\end{array}$ \\
\hline
\end{tabular}

Para Oviatt e McDougall (2004) uma BG necessita possuir recursos únicos para ser sustentável, porém a empresa necessita utilizar estratégias que dificultem ou impossibilitem a imitação de tais recursos. Para Knight e Cavusgil (2004) os recursos únicos se assemelham ao conceito de diferencial competitivo, em que o foco na qualidade é uma das estratégias para uma BG se manter sustentável.

As duas empresas colocam a qualidade técnica das suas equipes, produtos, serviços e o compromisso com seus clientes em atender suas necessidades dentro do tempo e qualidade previamente estabelecidos como sendo seus principais diferenciais competitivos, porém tais diferenciais aparentemente não são suficientes para explicar a sustentabilidade dessas empresas em um contexto internacional, pois em indústrias altamente desenvolvidas existe uma alta competitividade entre empresas de diversos países que também apresentam foco em qualidade, tornando assim os recursos únicos altamente imitáveis, dessa forma,é possível queas duas empresas estudadas tenham um diferencial dentro da indústria brasileira, que ainda se encontra em um estágio inicial de desenvolvimento, porém tais características apenas viabilizam a atuação dessas empresas em mercados altamente desenvolvidos, como o dos EUA, mas não garantem recursos exclusivos.

Oviatt e McDougall (2004) discutem algumas formas para evitar a imitação de recursos únicos de BGs, dentre elas está a criação de alianças com outras empresas para compartilhar custos. Nos casos Manifesto e Aquiris, as duas empresas buscaram criar alianças com grandes empresas internacionais de jogos eletrônicos. No caso da Aquiris, a empresa buscou alianças mais fortes com a criação de parcerias para o desenvolvimento de coproduções, e dessa forma divide os riscos de fracasso dos jogos eletrônicos com seus parceiros, e 
os dividendos dos jogos de sucesso. No caso da Manifesto as alianças foram feitas na forma de serviços de outsourcing, em que a empresa passa a desenvolver parte dos jogos dos seus clientes sem assumir os riscos de fracasso dos mesmos.Para os serviços de outsourcing a Manifesto mantém um contato constante com seus clientes, possibilitando o fortalecimento dos laços entre as empresas, e consequentemente a contratação de novos serviços.

Freeman, Edwards e Schroder(2006) também corroboram com a idéia de utilizar parcerias entre BGs e empresas de grande porte como forma de ganhar diferencial competitivo. No estudo foi verificado que diversas BGs buscam criar parcerias com grandes clientes com o objetivo de superar suas limitações.

Em resumo, é possível verificar que as duas empresas conseguiram recursos únicos não somente pelo foco na qualidade, mas também por meio de parcerias criadas com grandes empresas de jogos eletrônicos, cujas alianças proporcionaram a Aquiris e a Manifesto meios para se manterem no mercado internacional de forma sustentável.

\section{6.}

\section{Importância da criação de alianças e parcerias}

\begin{tabular}{|c|c|}
\hline \multicolumn{2}{|l|}{ Aquiris } \\
\hline $\begin{array}{lr}\text { Utilização } & \text { de } \\
\text { publishers } & \text { para } \\
\text { distribuição } & \text { de } \\
\text { jogos. } & \end{array}$ & $\begin{array}{l}\text { Nossos jogos têm publishers. A Cartoon Network, e a Rumble, } \\
\text { são nossos canais de distribuição, por exemplo. É através dessas } \\
\text { empresas, que, basicamente, estão hoje nossos jogos, nas } \\
\text { plataformas IOS e Android, no Facebook, em PCs, em browsers... }\end{array}$ \\
\hline $\begin{array}{lr}\text { Parcerias r romo } \\
\text { geradoras de } \\
\text { conhecimento. }\end{array}$ & $\begin{array}{l}\text { Então, há troca de experiência sobre isso, há troca de experiência } \\
\text { sobre estratégias de monetização no jogo. Porque, como eles têm } \\
\text { outros jogos, eles têm estratégias } \mathrm{X}, \mathrm{Y}, \mathrm{Z} \text { para aqueles jogos e } \\
\text { acabam compartilhando isso conosco para implementarmos no } \\
\text { nosso jogo também. }\end{array}$ \\
\hline $\begin{array}{lr}\text { Parcerias } & \text { como } \\
\text { geradoras de } & \text { denhecimento. }\end{array}$ & $\begin{array}{l}\text { Temos que buscar aperfeiçoamentos técnicos e de gestão, no } \\
\text { sentido de modelo de negócio, que é uma coisa que vem } \\
\text { mudando muito. O que antes era um jogo de caixinha passou a } \\
\text { ser um jogo vendido em plataformas internacionais, depois } \\
\text { passou a ser jogo freeto play. Hoje em dia, a maior parte dos } \\
\text { jogos é gratuita, mas temos que ter uma estratégia boa para } \\
\text { monetizar, com a venda de itens dentro do jogo. Então, é muito } \\
\text { importante beber da experiência internacional, porque nós [no } \\
\text { Brasil] estamos sempre um passo atrás. }\end{array}$ \\
\hline $\begin{array}{lr}\text { Parcerias } & \text { para } \\
\text { distribuição } & \mathrm{e} \\
\text { promoção } & \text { dos } \\
\text { jogos. } & \end{array}$ & $\begin{array}{l}\text { Estamos fazendo um jogo com um parceiro que tem uma série } \\
\text { extremamente famosa, que tem uma capacidade de promoção } \\
\text { incrível, e nós não estamos investindo todo o valor do projeto, } \\
\text { estamos investindo uma parcela. É claro que a parcela dos lucros } \\
\text { [para a Aquiris] vai ser menor também, mas o risco é muito baixo. } \\
\text { Se eu tentar criar um jogo como esse do nada, eu vou gastar uma }\end{array}$ \\
\hline
\end{tabular}




\begin{tabular}{|c|c|}
\hline & $\begin{array}{l}\text { grana desenvolvendo o jogo - que não é fácil - e depois ainda } \\
\text { vou ter que ter uma grana, quem sabe, ainda maior, para } \\
\text { promover esse jogo mundialmente. }\end{array}$ \\
\hline $\begin{array}{l}\text { Utilização de } \\
\text { parcerias como } \\
\text { forma de adquirir } \\
\text { novos clientes. }\end{array}$ & $\begin{array}{l}\text {...a Unit é uma parceria muito importante, [...] basicamente eles } \\
\text { nos servem como uma ponte }[\ldots . .] \text { eles nos dão o aval da nossa } \\
\text { qualidade também, porque eles nos indicam para alguns clientes. }\end{array}$ \\
\hline \multicolumn{2}{|l|}{ Manifesto } \\
\hline $\begin{array}{l}\text { Parcerias como } \\
\text { geradoras de } \\
\text { conhecimento. }\end{array}$ & $\begin{array}{l}\text { Trabalhando com a Zynga,com a Disney, estamos falando de } \\
\text { grandes empresas que são referências em todo mundo. Então, } \\
\text { participar de seus projetos e fazer parceria com eles, beber dessa } \\
\text { fonte de inspiração e conhecimento, é essencial para nós nos } \\
\text { mantermos em termos de vanguarda tecnológica, muito mais } \\
\text { ainda no Brasil. }\end{array}$ \\
\hline $\begin{array}{l}\text { Utilização de } \\
\text { parcerias como } \\
\text { forma de atestar } \\
\text { competência. }\end{array}$ & $\begin{array}{l}\text { Estar lá fora nos permite ter grandes cases interessantes e } \\
\text { clientes de peso, para nos ajudar em outras áreas. Então, nas } \\
\text { áreas em que trabalhamos aqui no Brasil, de gameficaçãoe de } \\
\text { games para marcas, ajuda bastante, na apresentação da } \\
\text { empresa,para atestar nossa qualidade experiência. }\end{array}$ \\
\hline $\begin{array}{lr}\text { Parcerias } & \text { para } \\
\text { distribuição } & \text { e } \\
\text { promoção } & \text { dos } \\
\text { jogos. } & \end{array}$ & $\begin{array}{l}\text { Essas parcerias não servem apenas para distribuir os jogos pelo } \\
\text { mundo, elas servem também como uma das principais formas de } \\
\text { promoção dos jogos, além de poder contribuir fortemente na fase } \\
\text { de testes dos jogos. [...] Então, esse é um modelo de produto e } \\
\text { não existe outra forma de fazer, a não ser que você próprio vá } \\
\text { investir na promoção, lançamento e distribuição do jogo. E para } \\
\text { fazer isso, você precisa, na verdade, além do investimento em } \\
\text { produção, de um investimento ainda maior para promoção do } \\
\text { jogo. São coisas bastante diferentes, então nós decidimos focar } \\
\text { exclusivamente na produção e trabalhar com diferentes parceiros } \\
\text { para o lançamento dos nossos jogos. }\end{array}$ \\
\hline $\begin{array}{l}\text { Utilização de } \\
\text { parcerias como } \\
\text { forma de adquirir } \\
\text { novos clientes. }\end{array}$ & $\begin{array}{l}\text { Através da MightyPlay que a gente tem trabalhado com a } \\
\text { produção de games para a...a Disney, por exemplo, a Sea World }\end{array}$ \\
\hline
\end{tabular}

As parcerias criadas pelas empresas estudadas foram feitas com empresas publishers. Como já visto na análise do setor de jogos eletrônicos, essas empresas têm diversas funções, e nesta parte do trabalho iremos abordar os motivos e as vantagens obtidas com a criação de parcerias com publishers, pelas empresas Aquiris Games e Manifesto Games.

A primeira vantagem, como visto anteriormente, está relacionada à criação de recursos únicos para as empresas, tornando-as sustentáveis no contexto internacional. 
Os parceiros publishers, que possuem uma abrangência global, são de grande importância para as duas empresas estudadas, pois são eles que divulgam e distribuem todos os jogos produzidos pela Aquiris e a Manifesto. Para Aquiris, os jogos são produzidos por meio de coproduções com publishers parceiros, e depois distribuídos por eles. No caso da Manifesto, a empresa atua de duas formas, a primeira é por meio de exportações diretas dos seus downloadable games, em que os publishers são os responsáveis pela divulgação e distribuição dos jogos, e a segunda é por meio da exportação de serviços de outsourcing, em que seus clientes, que são também publishers na maioria das vezes, contratam a empresa para produzir jogos ou parte deles.

Para buscar novas parcerias e clientes corporativos, as duas empresas adotaram uma postura proativa, e com o foco no mercado norte americano. Para aumentar as suas participações no mercado exterior a Aquiris e a Manifesto costumam participar de feiras internacionais, onde participam de rodadas de negócios com empresas de diversas regiões do mundo. Porém as parcerias já formadas também podem servir de fonte para criação de novos clientes, como já aconteceu nos dois casos estudados em que as empresas conseguiram formar clientes a partir de parceiros já estabelecidos.

Devido a pouca disponibilidade de recursos e a dificuldade de se conseguir financiamentos voltados para o desenvolvimento de jogos eletrônicos, são os parceiros da Aquiris e da Manifesto que financiam parte dos jogos desenvolvidos pelas empresas.

Freeman, Edwards e Schroder(2006) evidenciam que BG sofrem de três grandes limitações: ausência de economia de escala, falta de recursos financeiros, e aversão a risco. Nos casos das empresas estudadas aqui, aparentemente essas três limitações são contornadas com a utilização de parcerias com publishers. A falta de economia de escala é resolvida, pois os publishers têm como uma de suas principais funções a distribuição dos jogos em diversos mercados no mundo, a falta de recursos financeiros é contornada com o financiamento dos jogos pelos publishers, e por fim, a aversão a risco, que pode ser compreendido como a não propensão de uma firma em assumir projetos arriscados em mercados externos Freeman, Edwards e Schroder (2006),foram contornados pela Aquiris e Manifesto com o desenvolvimento de serviços de outsourcing e o desenvolvimento de coproduções, em que as empresas reduzem significativamente o risco dos seus projetos, que fica todo para os publishers no caso de outsourcing e é dividido no caso de coproduções. 
Com os trabalhos de outsourcing realizados pela Manifesto $\mathrm{e}$ as coproduções realizadas pela Adquirir, as empresas conseguem trocar experiências com grandes publishers, dessa forma suas parcerias servem também como fonte de conhecimento, permitindo a Aquiris e a Manifesto se manterem atualizadas sobre novas tecnologia, tendências de mercado, e também possibilitam a criação de portfólios das empresas que servem como comprovação de qualidade e experiência e consequentemente melhoram as chances de criação de novos contatos e clientes.

Por fim, os publishers podem atuar na fase de teste dos jogos produzidos pelas desenvolvedoras, pois quando um jogo é criado, ele deve passar por uma fase de testes para tentar encontrar possíveis falhas, porém devido às restrições financeiras de pequenas BGs, como a Aquiris e a Manifesto, essa fase é feita de forma modesta, permitindo que erros nos jogos passem despercebidos, porém com a ajuda dos publishers,esses testes ficam mais rigorosos, pois os publishers possuem uma enorme rede de jogadores que se dispõem a testar novos jogos e reportar os erros encontrados. 


\section{7 \\ Considerações finais}

Este estudo buscou investigar o processo de internacionalização de duas Born Globals brasileiras desenvolvedoras de jogos eletrônicos, e as estratégias dessas empresas para se manterem sustentáveis no mercado internacional. A relevância desse estudo se dá pela escassa quantidade de trabalhos sobre Born Globals em países emergentes, principalmente dentro do setor de jogos eletrônicos, que no Brasil ainda se mostra em fase embrionária. Assim, no estudo, buscou-se identificar as motivações para a internacionalização da Aquiris Games e Manifesto Games, bem como as estratégias adotadas para a internacionalização e para a sustentabilidade das empresas no mercado internacional.

O objetivo do estudo foi desdobrado em seis perguntas de pesquisa, que contemplam os seguintes aspectos: os principais determinantes dos processos de internacionalização das empresas; os critérios de seleção dos países; os fatores facilitadores e as barreiras ou obstáculos na internacionalização das empresas; as estratégias para sustentabilidade das empresas no mercado internacional; e os critérios para formação de alianças internacionais dessas empresas.

No referencial teórico foram abordados os seguintes aspectos: as principais características do fenômeno Born global, suas principais diferenças dos modelos tradicionais de internacionalização, os problemas existentes na definição de algumas características das BGs, e as principais diferenças nas definições de Born Globals e International New Ventures; os principais determinantes do processo de internacionalização de Born Globals, como: as influências globais, as influências da internet, dos fatores ambientais do país, dos fatores específicos da indústria,dos fatores específicos da empresa, da utilização de redes de relacionamento, e dos fatores individuais do empreendedor; por último, foi apresentada a literatura sobre estratégias de sustentabilidade de Born Globals. 
No estudo foi adotada metodologia de estudo de caso. O método foi adotado por se mostrar mais adequado a estudos que envolvem a complexidade do problema tratado neste trabalho e a sua natureza. O método viabilizou a uma profunda investigação das motivações, suas estratégias e eventos que caracterizaram os processos de internacionalização das empresas observadas. Também foi possível investigar as estratégias adotadas pelas empresas para se manterem sustentáveis em suas atuações no exterior.

Realizou-se uma descrição da indústria de jogos eletrônicos brasileira, buscando contextualizar o ambiente onde as empresas estudadas estão inseridas. Nesta descrição foram abordados os seguintes tópicos: os tipos de jogos existentes e suas finalidades, as características das empresas desenvolvedoras de jogos eletrônicos e dos publishers, as principais associações da indústria brasileira de jogos eletrônicos, as políticas de fomento a indústria no Brasil e no Mundo, o mercado de trabalho na indústria brasileira, a formação de profissionais para a indústria, e a internacionalização da indústria brasileira de jogos eletrônicos.

Realizou-se uma descrição detalhada dos casos das empresas Aquiris Games e Manifesto Games. Inicialmente foi desenvolvido um estudo das empresas com base em dados secundários colhidos de fontes diversas, que possibilitou a identificação das atividades internacionais das empresas, e parte dos seus históricos. A partir destes estudos preliminares foi possível a montagem de um roteiro de entrevistas semi estruturado em que foram abordadas questões que permitissem o melhor entendimento do processo de internacionalização das empresas. Assim, com a montagem do roteiro foi possível realizar as entrevistas, que viabilizaram $\mathrm{o}$ aprofundamento $\mathrm{e}$ esclarecimento de questões relacionadas às estratégias e decisões tomadas no processo de internacionalização da Aquiris Games e Manifesto Games. A partir das entrevistas foi possível desenvolver os casos das empresas, que abordaram diversos tópicos como: histórico das empresas, o perfil dos dirigentes, as características dos processos de internacionalização, as barreiras à internacionalização, e os facilitadores para a internacionalização. 


\section{1.}

\section{Conclusões}

Apesar da impossibilidade de generalização dos resultados deste trabalho, foi possível explorar questões relacionadas ao processo de internacionalização, e as estratégias para criação de sustentabilidade internacional das empresas Manifesto e Aquiris. Ainda que não seja possível a generalização estatística, neste trabalho foram feitas algumas reflexões pertinentes para a melhor compreensão das questões teóricas propostas.

\subsection{1.}

\section{O processo de internacionalização das empresas Aquiris e Manifesto}

Neste estudo foi possível verificar que dentre os determinantes de internacionalização encontrados na literatura, os que mais influenciaram o processo de internacionalização da Aquiris e Manifesto foram: a facilidade atual de exportar jogos eletrônicos, e a baixa atratividade do mercado brasileiro. Com a atuação de publishers internacionais e o uso de ferramentas de vendas de jogos e aplicativos online (como Apple Store, Android Market, Steam etc.) para quase todos os tipos de dispositivos eletrônicos, a exportação de jogos eletrônicos ficou tão simples quanto a venda de desses produtos no mercado doméstico. A Aquiris e a Manifesto começaram a desenvolver jogos eletrônicos em um momento econômico desfavorável para o Brasil, e que combinado aos altos impostos cobrados nas vendas desses produtos e aos altos níveis de pirataria existentes, faziam com que o mercado brasileiro ficasse muito pouco atraente, e consequentemente levavam as empresas do setor a procurar por alternativas, como a exportação de jogos.

Dentre as dificuldades enfrentadas, a que mais impactou as empresas estudadas foram os altos impostos cobrados, tanto no Brasil quanto no exterior. Os impostos cobrados tornavam as empresas de jogos eletrônicos brasileiras menos competitivas, inviabilizavam diversos projetos e muitas vezes era visto como um fator impeditivo para o crescimento das empresas no Brasil.

Com relação aos facilitadores do processo de internacionalização das duas empresas, o que mais se destacou foi a participação da Aquiris e Manifesto em feiras internacionais de jogos eletrônicos, que permitiram a criação de redes de relacionamento entre as duas pequenas empresas e grandes publishers internacionais. 
Por fim, a criação de parcerias com grandes publishers pode ser considerada como essencial para a atuação das duas empresas no exterior, pois foram eles os responsáveis pela promoção e distribuição dos jogos desenvolvidos pelo mundo, financiaram projetos dessas empresas que possuíam recursos limitados, participaram do desenvolvimento de jogos, e também a criaram outras vantagens indiretas para suas parceiras, como a troca de conhecimentos, a comprovação de qualidade das parceiras, e a ajuda na conquista de novos clientes. Diversos autores já evidenciaram a criação de parcerias como um fator importante para explicar a internacionalização precoce de BGs. Silva e Dib (2011) criaram uma lista, com base na literatura, dos principais fatores ligados a redes de relacionamento que influenciam a velocidade do processo de internacionalização, estão entre eles: uso intensivo de parcerias com outras empresas, integração a redes de negócios internacionais, e utilização de redes pessoais. Sharma \& Blomstermo (2003) propõem que modelos que se baseiam em conhecimento e em redes são apropriados para explicar o processo de internacionalização de BGs e que os laços criados com empresas internacionais podem fornecer informações relevantes sobre clientes e mercados, enquanto que empresas que criam uma rede de relacionamentos doméstica têm mais dificuldade para se internacionalizarem.

\subsection{2.}

\section{A criação de sustentabilidade internacional das empresas Aquiris e Manifesto}

Atualmente, devido a facilidade que existe em uma empresa de jogos eletrônico entrar no mercado internacional, a indústria de jogos eletrônicos está se tornando cada vez mais competitiva, e por isso está cada vez mais difícil para uma empresa criar recursos únicos que permitam a sua sustentabilidade internacional. As duas empresas colocam como diferencial competitivo para atuação internacional a qualidade técnica dos seus produtos e serviços, porém o diferencial na qualidade técnica aparentemente já não pode ser considerado sozinho um recurso único, devido à alta competitividade internacional. Assim, neste estudo foi possível verificar que a Aquiris Games e a Manifesto Games também tinham como estratégia para o desenvolvimento de recursos únicos, a criação de parcerias com grandes publishers internacionais, que as ajudassem na distribuição, promoção, financiamento, suporte de desenvolvimento de jogos eletrônicos etc. Dessa forma, com a conquista desses parceiros, as duas 
empresas conseguiram uma relativa segurança em suas atuações internacionais.

A necessidade apresentada pelas duas empresas em desenvolver recursos únicos confirmaram a teoria de Oviatt e McDougall (2004) que coloca a criação de recursos únicos como forma de gerar sustentabilidade internacional para BGs. A criação de parcerias com grandes publishers como forma de criar os recursos únicos também corrobora com a teoria de Freeman, Edwards and Schroder (2006), que argumenta que uma das estratégias para BGs superarem suas deficiências é justamente a de criar parcerias com empresas de grande porte.

A busca por recursos únicos fica mais evidente no caso da Manifesto, que começou sua atuação internacional criando parcerias com publishers apenas com o objetivo de distribuir e promover seus jogos, porém com o passar do tempo começou a buscar parcerias mais fortes, por meio de trabalhos de outsourcing, permitindo que a empresa tivesse uma interação maior com seus parceiros e também diminuísse seus riscos.

\section{2. \\ Recomendações para a prática empresarial}

Desenvolvedoras brasileiras de jogos eletrônicos que tiverem interesse em se internacionalizar podem utilizar este estudo para verificar as dificuldades enfrentadas e as facilidades encontradas pelas empresas Aquiris e Manifesto não somente no processo de internacionalização, mas também em relação às estratégias utilizadas para se manterem no mercado internacional.

A atuação internacional pode servir de chancela para a obtenção de negócios dentro do Brasil. Foi verificado nos dois casos que as empresas utilizavam seu know-how e seu portfólio internacional para conquistar clientes no Brasil, como no Brasil ainda são poucas as empresas desenvolvedoras de jogos eletrônicos, e a grande maioria delas ainda se encontra em uma fase embrionária, uma empresa que possua experiência internacional com parceiros de grande porte, certamente conseguirá se destacar entre as empresas nacionais. 
Uma empresa brasileira que deseja se internacionalizar poderá encontrar melhores negócios por meio da prestação de serviços (outsourcing) para grandes empresas internacionais de jogos eletrônicos, pois os impostos pagos na prestação de serviços são significativamente inferiores aos pagos com a exportação direta de jogos eletrônicos, além disso, o outsourcing permite evoluir na construção de relacionamentos com os parceiros no exterior, o que não é possível com os grandes portais de jogos eletrônicos que apenas distribuem os jogos produzidos, e também é possível adquirir mais experiência no desenvolvimento dos jogos, pois todo o processo de desenvolvimento do jogo é acompanhado pelas duas empresas, que trocam idéias e experiências todo o tempo.

As feiras internacionais de jogos eletrônicos aparentemente são uma excelente forma de conseguir novos parceiros e clientes para coproduções e serviços de outsourcing. As empresas utilizam as feiras e eventos específicos de jogos eletrônicos como forma principal de prospectar novos clientes, fazer contatos e gerar oportunidades de negócio. É também a principal forma de divulgação da empresa no exterior.

É preciso cautela ao decidir se internacionalizar, principalmente quando se é uma empresa jovem e de pequeno porte, que não possui experiência internacional e conta apenas com poucos recursos. Nos casos estudados foi possível verificar grande dificuldade das empresas ao lidar com questões tributárias e jurídicas, onde as duas empresas sentiram a necessidade de contratar consultorias para lidar com algumas questões que poderiam inclusive levá-las a insolvência, sendo assim, é imprescindível que uma pequena Born Global verifique a existência de recursos suficientes para contratar serviços terceiros que a auxilie no processo de internacionalização. No caso da Aquiris Games, devido a sua falta de experiência em criar contratos com parceiras internacionais sentiu a necessidade de contratar um escritório de advocacia para analisar contratos mais justos para a empresa, essa necessidade surgiu da má análise de um contrato assinado que acabou gerando grandes dificuldades financeiras para a empresa. No caso da Manifesto a empresa se viu forçada a contratar uma consultoria tributária, pois devido à complexidade das taxas cobradas no Brasil e em outros países, principalmente os EUA, se viu pagando um valor ainda maior que o necessário, em que muitas vezes tornava alguns projetos inviáveis. 


\section{3.}

\section{Recomendações para estudos futuros}

O estudo de caso de outras empresas de jogos eletrônicos que tenham se internacionalizado de forma rápida e precoce, e busque evidencias que apontem os motivos para a internacionalização, os acertos e erros cometidos, as dificuldades enfrentadas e os facilitadores à internacionalização.

Outra possibilidade é o levantamento das empresas desenvolvedoras de jogos eletrônicos no Brasil por meio das associações do setor, a indústria de jogos eletrônicos no Brasil ainda é muito pouco estudada. Foi verificado durante o desenvolvimento deste estudo que os dados sobre o setor são escassos e normalmente defasados, porém foi verificada também a boa vontade e a prédisposição das associações e empresas do setor em ajudar na realização de estudos mais aprofundados. A partir do levantamento das empresas do setor será possível fazer investigações quantitativas sobre o processo de internacionalização do setor, que permitam identificar suas características únicas.

É possível também retomar o estudo do processo de internacionalização das empresas Aquiris e Manifesto, dentro de alguns anos, com o objetivo de avaliar os resultados das decisões tomadas que foram identificadas no presente estudo, ou seja, será possível avaliar o grau de desenvolvimento e os impactos futuros dessas decisões. Será possível, por exemplo, verificar se a estratégia da Manifesto em colocar representantes da empresa nos EUA e Inglaterra surtiram efeitos positivos para a empresa, ou no caso da Aquiris se a sua estratégia de atuação internacional visando apenas coproduções de jogos eletrônicos menos arriscadas será mantida ao longo de alguns anos. 
8

\section{Referências bibliográficas}

BATAS, S.; LIU, L. The internationalization process of born global high technology SMEs: The moderating role of business and social networks. ... Conference (SIIC), 2013 Suzhou-Silicon Valley ..., 2013.

BLOODGOOD, J.; SAPIENZA, H. J.; ALMEIDA, J. G. The internationalization of new high-potential US ventures: Antecedents and outcomes. p. 61-77, 1996.

CHETTY, S.; CAMPBELL-HUNT, C. A Strategic Approach to Internationalization: A Traditional Versus a "Born-Global" Approach. Journal of International Marketing, v. 12, n. 1, p. 57-81, mar. 2004.

DIB, L. A. Caracterizando o processo de internacionalização born global: discussão sobre a conceituação empírica do fenômeno e hipóteses de pesquisa. XXXII EnANPAD, p. 1-16, 2008.

$O$ processo de internacionalização de pequenas e médias empresas eo fenômeno born global: estudo do setor de software no Brasil. Universidade Federal RJ, Rio de Janeiro, 2008.

; ROCHA, A.; SILVA, J. F. The internationalization process of Brazilian software firms and the born global phenomenon: Examining firm, network, and entrepreneur variables. Journal of International Entrepreneurship, v. 8, n. 3, p. 233-253, 17 fev. 2010.

FREEMAN, S.; EDWARDS, R.; SCHRODER, B. How Smaller Born-Global Firms Use Networks and Alliances to Overcome Constraints to Rapid Internationalization. Journal of International Marketing, v. 14, n. 3, p. 33-63, set. 2006.

GABRIELSSON, M. Branding Strategies of Born Globals. Journal of International Entrepreneurship, v. 3, n. 3, p. 199-222, set. 2005.

;; MANEK KIRPALANI, V. H. Born globals: how to reach new

business space rapidly. International Business Review, v. 13, n. 5, p. 555-571, out. 2004.

.; SASI, V.; DARLING, J. Finance strategies of rapidly-growing Finnish SMEs: Born Internationals and Born Globals. European Business Review, v. 16, n. 6, p. 590-604, 2004.

GIL, A. C. Como Elaborar projetos de Pesquisa. [s.I: s.n.].

JOLLY, V. K.; ALAHUTHA, M.; JEANNET, J. P. Challenging the incumbents: how high technology start ups compete globally. Journal of Strategic Change, v. 1, n. 2, p. 71-82, 1992. 
JONES, M. V.; COVIELLO, N.; TANG, Y. K. International Entrepreneurship research (1989-2009): A domain ontology and thematic analysis. Journal of Business Venturing, v. 26, n. 6, p. 632-659, nov. 2011.

KNIGHT, G. A.; CAVUSGIL, S. T. Innovation, organizational capabilities, and the born-global firm. Journal of International Business Studies, v. 35, n. 2, p. 124-141, 8 jan. 2004.

The Born Global Firm - a Challenge to Traditional

Internationalization Theory. Advances in International Marketing, v. 8, p. 11-26, 1996.

.; MADSEN, T. K.; SERVAIS, P. An inquiry into born-global firms in Europe and the USA. International Marketing Review, v. 21, n. 6, p. 645-665, 2004.

KOCAK, A.; ABIMBOLA, T. The effects of entrepreneurial marketing on born global performance. International Marketing Review, v. 26, n. 4/5, p. 439-452, 2009.

LOPEZ, L. E.; KUNDU, S. K.; CIRAVEGNA, L. Born global or born regional? Evidence from an exploratory study in the Costa Rican software industry. Journal of International Business Studies, v. 40, n. 7, p. $1228-1238,30$ out. 2008.

MADSEN, T. K. Early and rapidly internationalizing ventures: Similarities and differences between classifications based on the original international new venture and born global literatures. Journal of International Entrepreneurship, v. 11, n. 1, p. 65-79, 20 dez. 2012.

; SERVAIS, P. The internationalization of born globals: an evolutionary process? International Business Review, v. 6, n. 6, p. 561583, 1997.

MCDOUGALL, P. International versus domestic entrepreneurship: new venture strategic behavior and industry structure. Journal of Business Venturing, p. 387-400, 1989.

MCNAUGHTON, R. O. D. B. The Number of Export Markets that a Firm Serves: Process Models versus the Born-Global Phenomenon. $\mathrm{n}$. 519, 2003.

MOEN, $\varnothing$. The Born Globals: A New Generation of Small European Exporters. International Marketing Review, v. 19, n. 2, p. 156-175, 2002. ; SERVAIS, P. Born Global or Gradual Global? Examining the Export Behavior of Small and Medium-Sized Enterprises. Journal of International Marketing, v. 10, n. 3, p. 49-72, set. 2002. 
OVIATT, B. M. Defining international entrepreneurship and modeling the speed of internationalization. Entrepreneurship theory and ..., $\mathrm{n}$. April, p. 537-553, 2005.

.; MCDOUGALL, P. Challenges for internationalization process theory: The case of international new ventures. MIR: Management International Review, 1997. ; Toward a theory of international new ventures. Journal of International Business Studies, v. 25, n. 1, p. 45-64, 1994. ; . Toward a theory of international new ventures. Journal of International Business Studies, v. 36, n. 1, p. 29-41, 18 nov. 2004.

RENNIE, M. Global competitiveness: Born global. McKinsey Quarterly, v. 4 , p. $45-52,1993$.

RIALP, A.; RIALP, J.; KNIGHT, G. A. The phenomenon of early internationalizing firms: what do we know after a decade (1993-2003) of scientific inquiry? International Business Review, v. 14, n. 2, p. 147166, abr. 2005.

SHARMA, D. D.; BLOMSTERMO, A. The internationalization process of Born Globals: a network view. International Business Review, v. 12, n. 6, p. 739-753, dez. 2003.

SILVA, R. S. M. .; DIB, L. A. Processos de Internacionalização de Born Globals: Estudo de Casos de Empresas Brasileiras de Software. V Encontro de Estudos em Estratégia. Anais...2011

SINKOVICS, N.; SINKOVICS, R. R.; JEAN, R. J. B. The internet as an alternative path to internationalization? International Marketing Review, v. 30, n. 2, p. 130-155, 2013.

YIN, R. Case Study Research: Design and Methods. [s.l.] Sage Publications Inc., 2003.

ZOU, H.; GHAURI, P. N. Internationalizing by learning: the case of Chinese high-tech new ventures. International Marketing Review, v. 27, n. 2, p. 223-244, 2010. 
9

Referências da análise da indústria de jogos eletrônicos

ACIGAMES. ACI Games - Associação Comercial, Industrial e Cultural de Games. Disponível em: <http://www.acigames.com.br/>. Acesso em: 25 ago. 2013a.

\begin{tabular}{cccccr} 
& VIDEOGAMES & E & PERSPECTIVAS & DE & MERCADO \\
\hline NACIONAL. & {$[\mathrm{s} . \mathrm{l}:$} & & s.n.]. & Disponível & em:
\end{tabular}
$<$ http://www.slideshare.net/moacyrajunior/videogame-perspectivas-demercado>.

CARDOSO, M. V. A PROPOSIÇÃO DE UM MODELO DE ANÁLISE PARA A INDÚSTRIA CRIATIVA DE VIDEOGAMES NO BRASIL. [s.I.] UNIVERSIDADE DE SÃO PAULO - FACULDADE DE ECONOMIA, ADMINISTRAÇÃO E CONTABILIDADE, 2013.

CHEN, S. The Social Network Game Boom. 2009.

DIETZ, J. Metacritic's 3rd Annual Game Publisher Rankings. Disponível em: <http://www.metacritic.com/feature/game-publisherrankings-for-2012-releases>.

HELYAR, J. Outsourcing: A Passage Out of India. Disponível em: $<$ http://www.brasscom.org.br/brasscom/Portugues/detNoticia.php?codNoti cia=56\&codArea=2\&codCategoria=26>. Acesso em: 22 ago. 2013.

LEMOS, I. S.; QUANDT, C. O. Exportação de Jogos Eletrônicos para Celulares: um Estudo na Indústria Brasileira. 2008.

MORRIS, C. P2P, B2P, F2P models of MMOs. Disponível em: $<$ http://students.expression.edu/calebmorris 1/2013/08/12/p2p-b2p-f2pmodels-of-mmos/>. Acesso em: 24 out. 2013.

OBSCURE. Computer Game Publishing (an overview). Disponível em: $<$ http://www.obscure.co.uk/articles-2/computer-game-publishing/>. Acesso em: 20 fev. 2014.

PELIZZARI, R. Publisher Vs Developer, entenda as diferenças delas no desenvolvimento de games. Disponível em: $<$ http://mtv.uol.com.br/gamemakers/blog/publisher-vs-developer-entendadiferen\%C3\%A7-delas-no-desenvolvimento-de-games>. Acesso em: 21 ago. 2013.

QUERETTE, E. et al. Políticas públicas para a indústria de games : uma agenda para o Brasil. p. 13-22, 2012. 
Relatório de Investigação Preliminar: O Mercado Brasileiro de Jogos Eletrônicos. $\quad$ [s.l: $\quad$ s.n.]. Disponível em: <http://direitorio.fgv.br/node/1872>.

ROCHA, V. Atributos Competitivos e Ações Estratégicas Para o Cluster de Games de Pernambuco. fbv.edu.br, 2010.

SOFTEX. Perfil das Empresas Brasileiras Exportadoras de Software. Brasília. Softex, 2005.

UOL. A História do Videogame. Disponível em: <http://jogos.uol.com.br/reportagens/historia/1961.>. Acesso em: 21 ago. 2013. 


\section{Anexos}

10.1

Anexo 1 - Exemplos de Jogos Eletrônicos Desenvolvidos pela Aquiris

- Eu Atleta

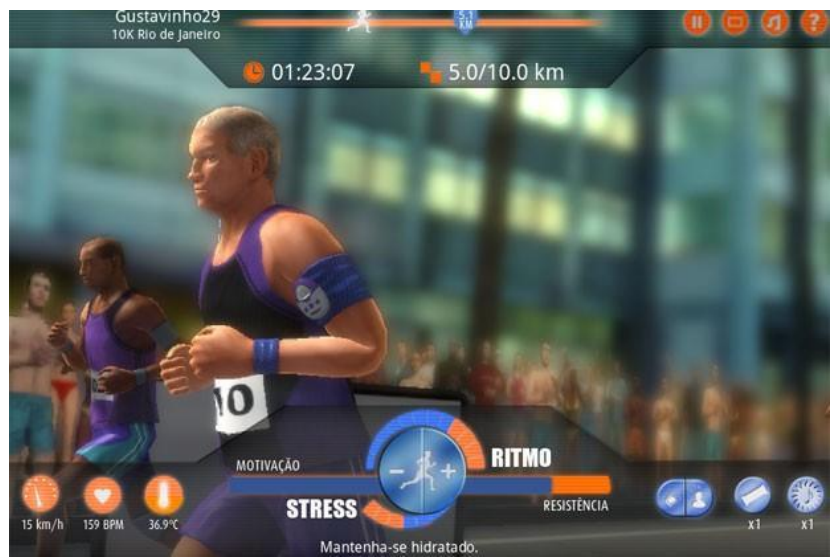

O game "Eu Atleta", desenvolvido para a Rede Globo, simula corridas de rua, em que o jogador deve definir a forma e ritmo da corrida e gerenciar a motivação, o estresse (batimentos cardíacos) e a resistência do atleta, dando água ou um gel com aminoácidos. Além disso, precisa levar em conta a temperatura e a direção do vento. Os eventos simulados nos jogos são três: Meia Maratona de São Paulo, Eu Atleta 10K Rio e Volta da Pampulha. O jogo, desenvolvido pela Aquiris para a Rede Globo, foi lançado ao final de $2012^{\mathrm{xix}}$.

- Ballistic 

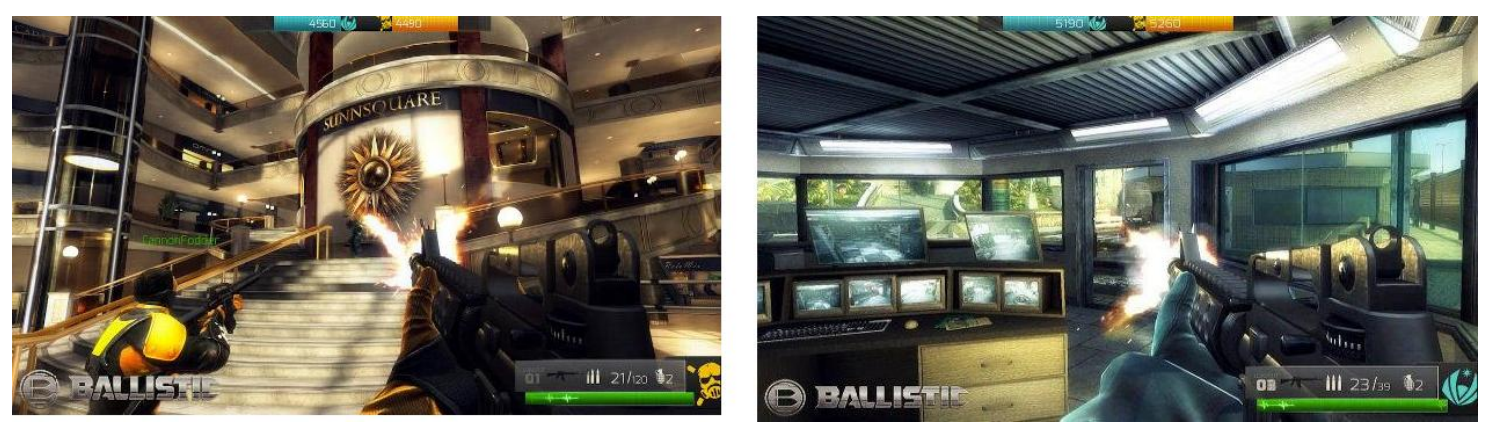

Este jogo é distribuído pela Rumble Entertainment. O jogo é caracterizado como um jogo de tiro. De acordo com um site especializado tem "jogabilidade simples e rápida, mas que também possui profundidade para que os fãs passem horas entretidos com o game. Pelo pouco apresentado nas imagens e nos trailers, parece mesmo ser um título impressionante quando levamos em conta que ele é inteiramente rodado em browsers"xx.

O jogo é do tipo fremium, ou seja, gratuito até certo ponto, mas oferecendo complementos pagos caso o jogador deseje se aprofundar. O Ballistic ganhou o prêmio Melhor Jogo no Aspecto Tecnológico na Categoria PC/Web do SBGames 2013, que é o evento brasileiro de desenvolvimento de jogos. 
- Axé Music Star - Get Them Back

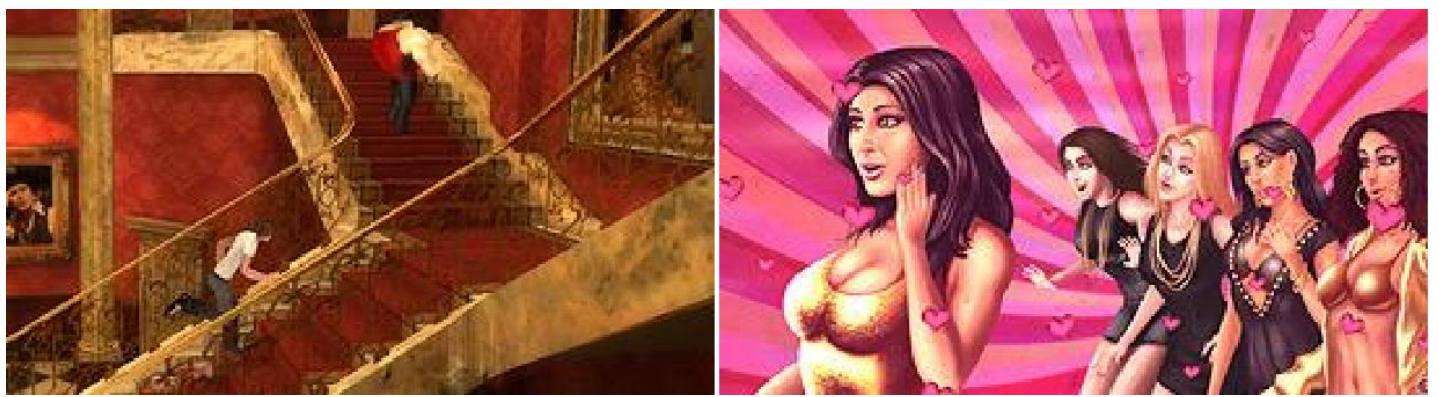

- $\quad$ Super Vôlei Brasil 2
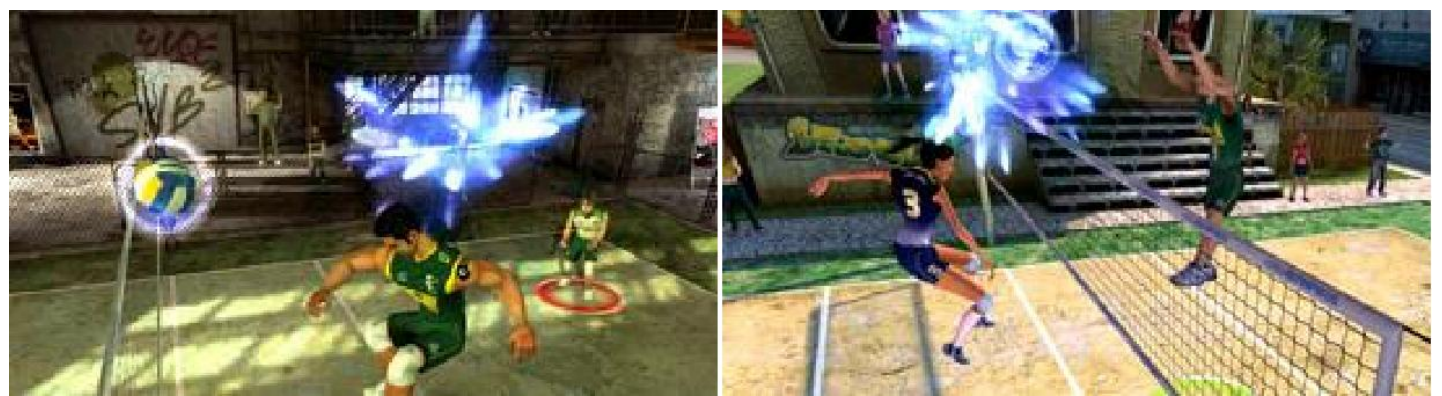

- Casas Bahia 56 Anos
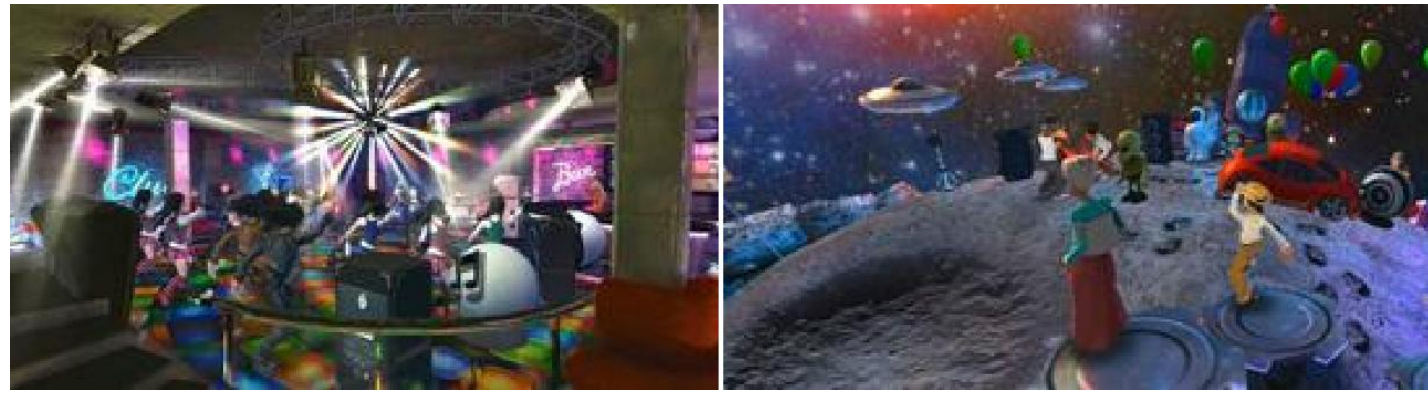

- Embraer Executive Jets
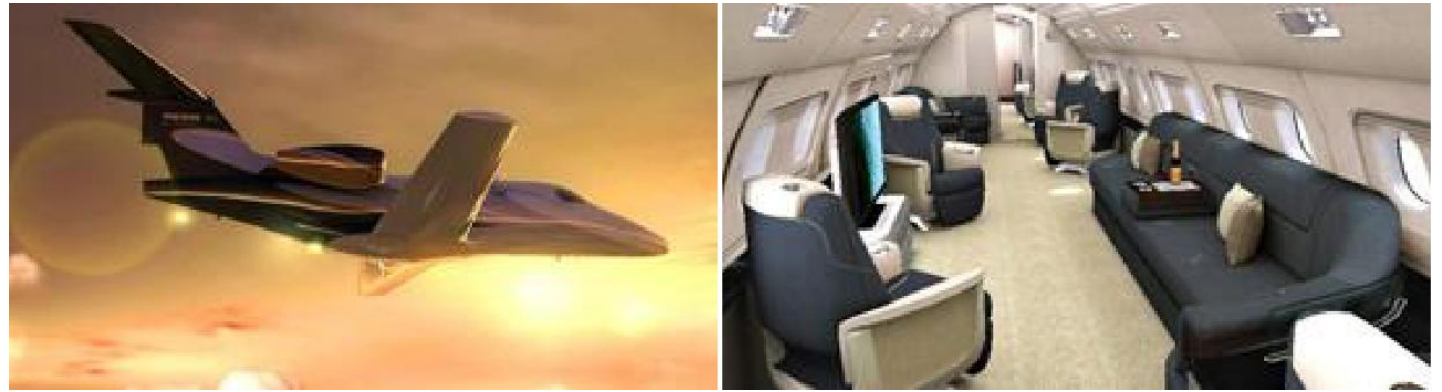

- Gillette Young Guns Challenge
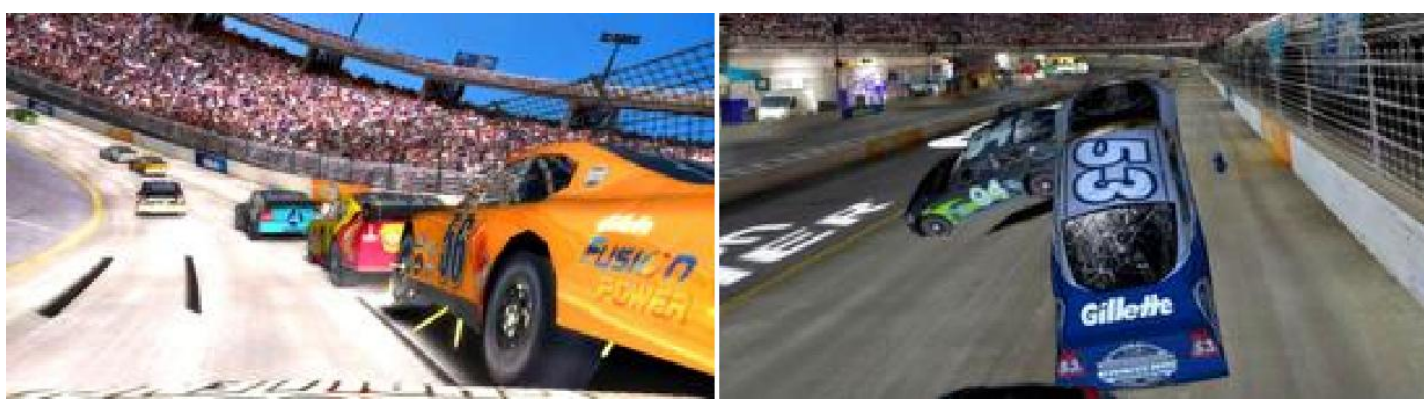


\section{2}

\section{Anexo 2 - Unity Technologies}

A Unity Technologies desenvolveu uma plataforma para criação dejogos eletrônicos e para experiências interativas em 3D e 2D, que pode ser usada para celulares, web, computadores, console e outras formas.

A empresa tem sua sede em San Francisco, Califória (EUA). Dispõe ainda de escritórios em: Alemanha, Canadá, Cingapura, China, Colômbia, Coreia, Dinamarca, Finlândia, Japão, Lituânia, Reino Unido, Suécia e Ucrânia..

Alguns dados relativos à empresa:

2 milhões de desenvolvedores registrados que utilizam a plataforma Unity em todo o mundo.

400 mil desenvolvedores ativos por mês.

225 milhões de instalações de jogadores na web.

$\mathrm{N}^{0} 1$ em tecnologia de desenvolvimento para jogos em mídias móveis, sendo usada por $53 \%$ dos desenvolvedores.

Fonte: http://unity3d.com/company/public-relations

10.3

Anexo 3 - Jogos Eletrônicos Desenvolvidos pela Manifesto Games

- Fruits inc. 

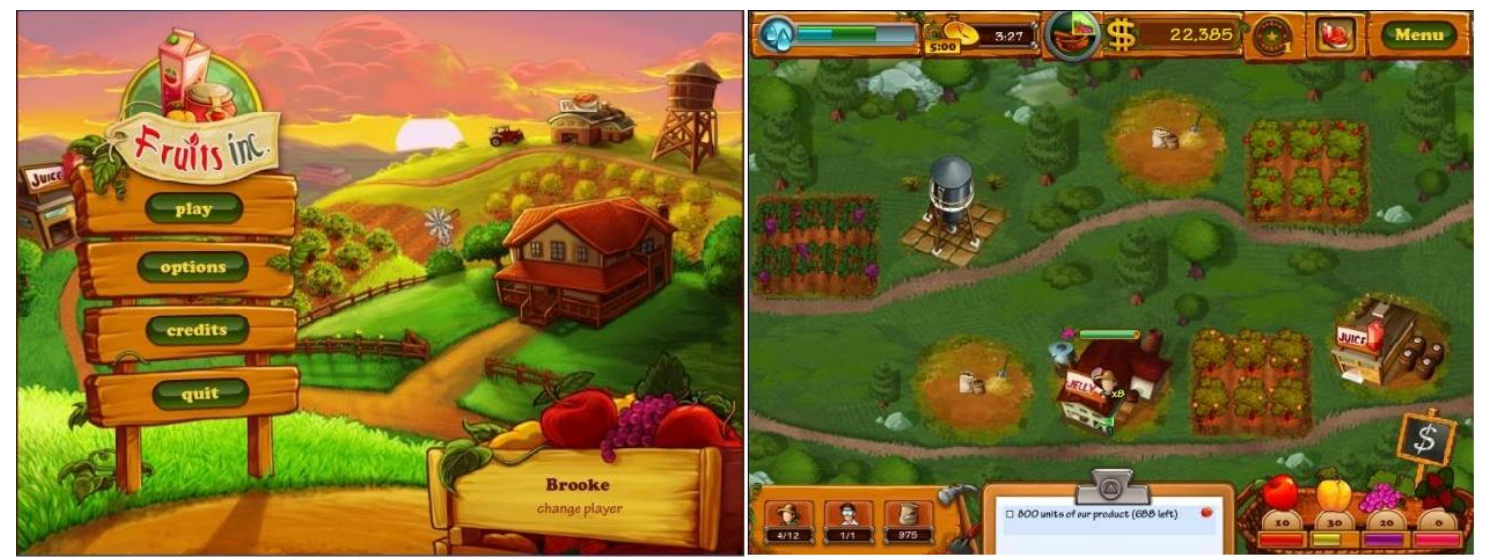

- Merlin Christmas
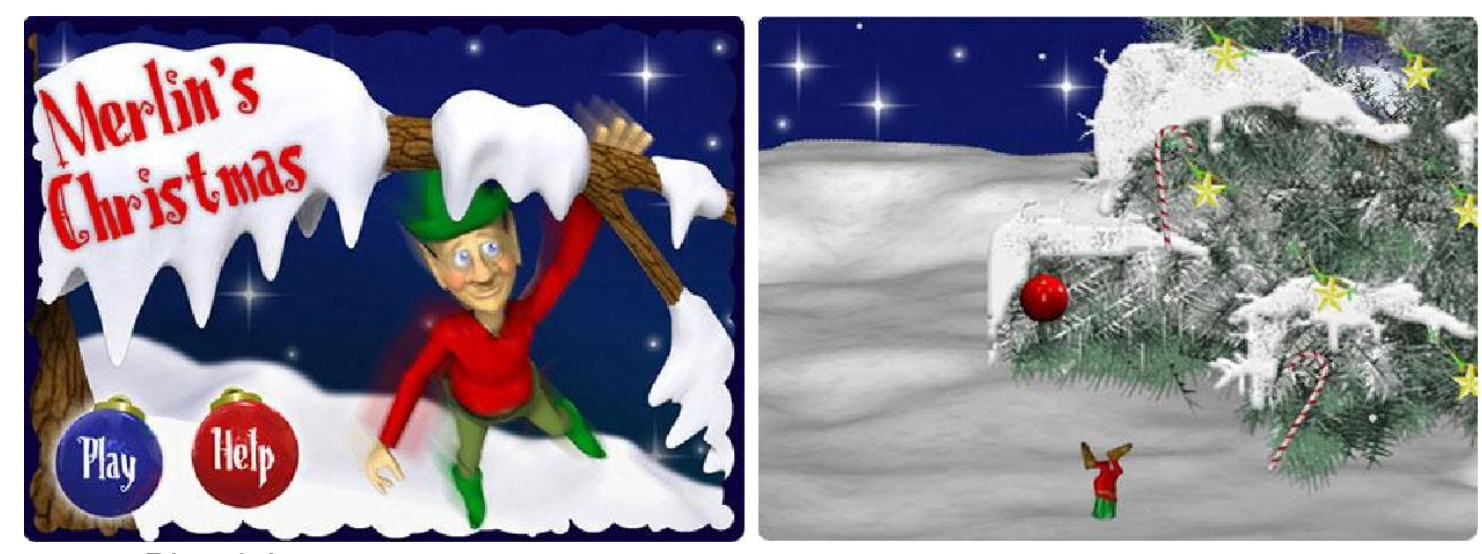

- Pizzaiolo
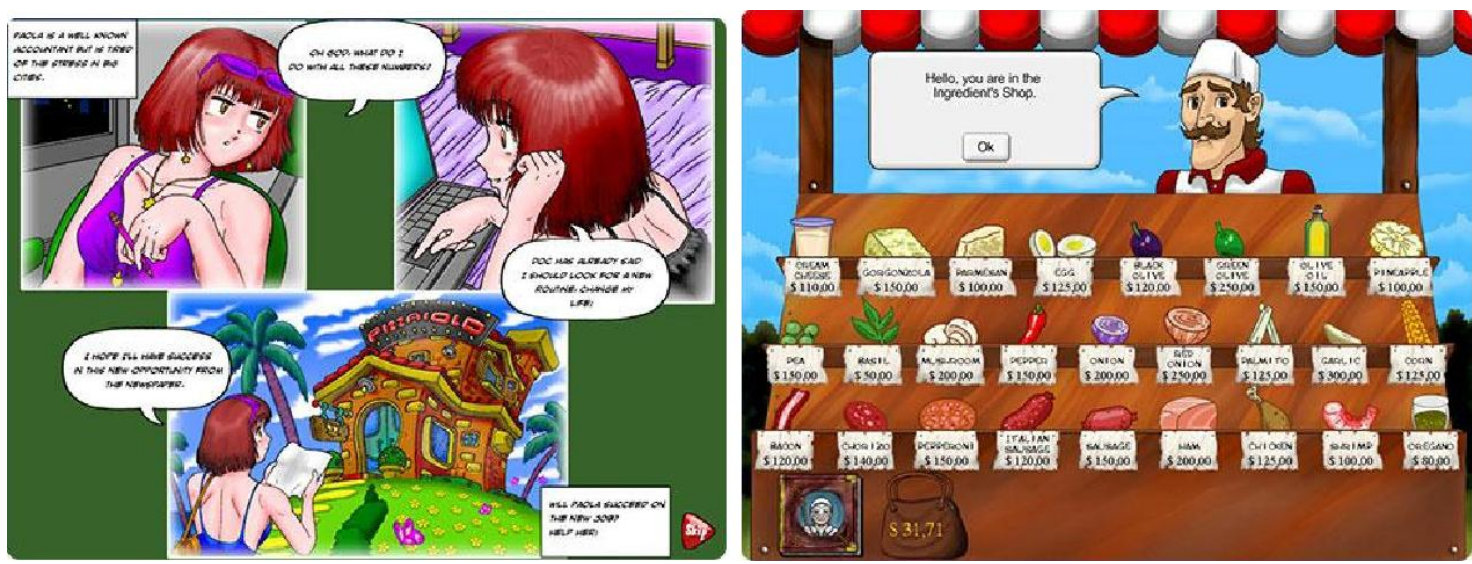
10.4

Anexo 4 - Notas e Referências dos casos

'O termo jogos casuais refere-se a jogos mais simples e que podem ser facilmente aprendidos, comparativamente com os jogos tradicionais, mais complexos, que tomam mais tempo e exigem mais dedicação do jogador.

iijogo com finalidade de propaganda. O termo advergame é um neologismo, que combina as palavras advertising (propaganda) e game (jogo).

iiijogo com capacidade para centenas de milhares de jogadores simultaneamente, que geralmente jogam online e apresentam ao menos um cenário em comum.

ivPalestra disponível em http://portuguese.unity3d.com/unity/multiplatform/

'Saraiva, J. Boas ideias em busca de investidores. Valor, 28.09.2012. Disponível em http://www.valor.com.br/financas/2847512/boas-ideias-em-busca-de-investidores.

viUma distribuidora de games é uma companhia que distribui jogos produzidos pela própria empresa ou por desenvolvedoras de jogos. São responsáveis pela comercialização, cobrindo as atividades relacionadas a marketing.

${ }^{\text {vii }}$ Nos jogos de tiro o jogador dispõe de uma arma e pode atirar com ela livremente.

viiiEncontro mundial dos desenvolvedores da Unity.

${ }^{\text {ix} P a l e s t r a ~ d i s p o n i ́ v e l ~ e m ~ h t t p: / / u n i t y 3 d . c o m / u n i t e / a r c h i v e / 2012 ~}$

${ }^{x}$ Abragames cria programa para exportar games feitos no Brasil. Disponível em http://g1.globo.com/tecnologia/games/noticia/2013/07/abragames-cria-programa-paraexportar-games-feitos-no-brasil.html

${ }^{x i} A$ pré-incubadora Recife BEAT - Base para Empreendimentos de Alta Tecnologia- foi criada pelo Centro de Informática (CIn) da UFPE em 1997, com o objetivo de estimular o empreendedorismo entre seus alunos. A meta principal é fazer com que os alunos considerassem a criação de novas empresas de informática, a partir de ideias inovadoras. (Disponível em http://www2.cin.ufpe.br/site/secao.php?s=5\&c=65).

${ }^{x i i}$ O C.E.S.A.R é um centro privado de inovação, com sede em Recife, que utiliza engenharia avançada em Tecnologias da Informação e Comunicação (TICs) com o propósito de oferecer respostas a problemas complexos de diversos setores, como telecomunicações, eletroeletrônicos, automação comercial e financeira, mídia, energia, saúde e agronegócios. (Disponível em http://www.cesar.org.br/ site/cesar/organizacao).

xiii Games para marcas (games for brands) é a utilização de jogos eletrônicos para promover uma determinada marca, produto ou serviço. 
xiv“Gameficação" é criação de jogos para as mais diversas áreas das empresas e outras organizações, com o intuito de transformar aatividades rotineiras em experiências mais divertidas e motivadoras.

${ }^{\mathrm{xv}}$ Outsourcing se refere à prestação de serviços na produção de jogos para atender a terceiros.

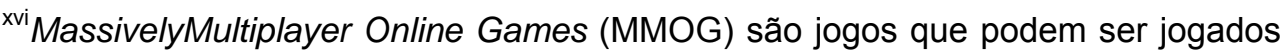
simultaneamente por grande número de jogadores online.

${ }^{\text {xvii } F e r r a m e n t a ~ d e ~ c o m u n i c a c ̧ a ̃ o ~ c o m ~ a ́ u d i o ~ e ~ v i ́ d e o ~ e m ~ t e m p o ~ r e a l ~ v i a ~ i n t e r n e t . ~}$

xviii Simões, K. Mercado de games abre caminhos no exterior. Valor, 29.06.2012. Disponível em http://www.valor.com.br/especiais/2732562/mercado-de-games-abrecaminhos-no-exterior

${ }^{x i x}$ Rede Globo lança game que simula corridas de rua no site "Eu Atleta". 14.11.2012. http://g1.globo.com/tecnologia/noticia/2012/11/rede-globo-lanca-game-quesimula-corridas-de-rua-no-site-eu-atleta.html

${ }^{x x}$ Velloso, F. Ballistic, um FPS brasileiro, terá lançamento mundial. TechTudo Site de Tecnologia da Globo, 10.04.2013. Disponível em http://www.techtudo.com.br/jogos/noticia/2013/04/ballistic-um-fps-brasileiro-teralancamento-mundial.html 